\title{
Fairness Versus Efficiency in Environmental Law
}

\author{
Shi-Ling Hsu
}

The principle which has exercised the greatest influence upon governments is that of sympathy and antipathy. In fact, we must refer to that principle all those specious objects which governments pursue, without having the general good for a single and independent aim; such as good morals, equality, liberty, justice, power, commerce, religion; objects respectable in themselves, and which ought to enter into the views of the legislator; but which too often lead him astray, because he regards them ends, not as means. He substitutes them for public happiness, instead of making them subordinate to it.

- Jeremy Bentham, The Theory of Legislation

$* * * * *$

Like many other areas of law, the development of environmental law has been strongly influenced by notions of fairness. This should not be surprising, since environmental law has been developed by lawyers, who are self-selected to be fairness-oriented and trained to think in terms of fairness. While large environmental gains have been achieved in the thirtyyear history of environmental law, progress seems to have reached a plateau. Partisanship has poisoned the debate on how best to proceed in making further environmental progress. I attribute the failings and the current stalemate in environmental law to our obsession with fairness. Fairness-thinking has created a culture where stakeholders are conditioned to make self-serving arguments, not considered judgments about the public

Copyright (C) 2004 by the Regents of the University of California.

* Associate Professor of Law, George Washington University Law School. The author acknowledges the research assistance of Alex Hallett, Andrew Szekely, Christina Dimock, and Mark Seidman, and the help and comments of Dan Cole, Arnold Reitze, Richard Pierce, Gregory Maggs, William Bratton, Larry Mitchell, Michael Selmi, David Driesen, Fred Cheever, Rob Verchick, Joshua Schwartz, Spencer Overton, J.B. Ruhl, Bill Andreen, Luoheng Han, Doug Kysar, Jonathan Nash, and participants at the Midwestern Law and Economics Association annual meeting. Any remaining errors are my responsibility alone. 
interest. While this is true in many areas of law, this has become especially troubling in environmental law.

$I$ propose that environmental law and policymakers pay more attention to efficiency arguments and efficiency-thinking. While I do not propose a tyranny of economists to supplant fairness-thinking, I argue that efficiency-thinking can provide an important complement to the fairnessthinking that has dominated environmental law and policy. This article explores the theoretical arguments for fairness-based and efficiency-based programs, and examines the empirical support for some of these arguments. The theoretical arguments for an increased role for efficiencythinking are quite clear. The evidence for more efficiency-based environmental regulation is somewhat thin, but with some important caveats, vindicates the economic theory in support of efficiency-based regulation.

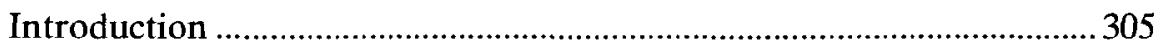

I. What Is Fairness In Environmental Law?.....................................313

A. Fairness As The Equal Distribution Of Burdens And

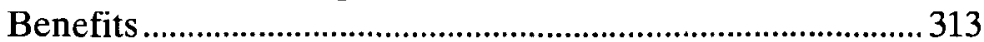

B. Fairness As Avoiding Retroactive Regulation ......................316

C. Fairness In The Retributive Sense......................................... 318

II. What Is Wrong With Fairness? ................................................... 320

A. A Public Choice Perspective ................................................... 323

B. Egocentrism And The Narrowing Windows of

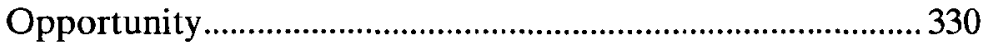

C. Identifiability And The Focus On The Polluter...................... 332

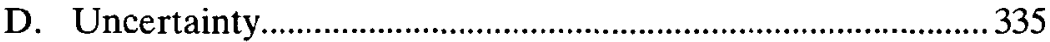

III. What Is Efficiency In Environmental Law?................................. 337

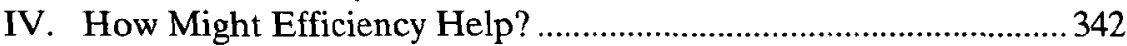

A. Efficiency Can Help Remedy The Problems Posed By Fairness-Thinking ................................................................ 342

B. Efficiency Encompasses Values Expressed By Fairness....... 345

C. Efficiency Analysis Is More Transparent Than Fairness...... 350

D. Efficiency Can Better Protect The Public Interest .................356

E. Efficiency Can Produce A More Dynamic Economy ........... 357

V. Fairness Versus Efficiency In Practice .........................................358

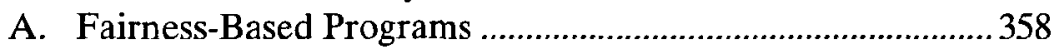

1. New Source Review And Grandfathering Under The

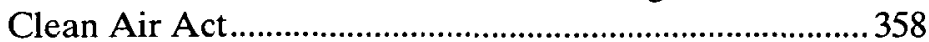

2. Emissions Rate Standards Under The Clean Air Act ....360

3. Nationally Uniform Effluent Standards Under The Clean Water Act 


\section{Greenhouse Gas Emissions Under The Kyoto}

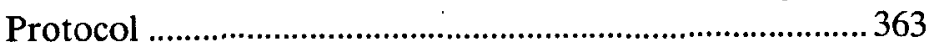

B. Efficiency-Based Programs ................................................... 364

1. Decentralized Trading Programs......................................365

2. Regulatory Bargaining Programs ...................................... 367

C. Have Efficiency Programs Helped? ........................................ 369

1. Have Efficiency Programs Created Greater

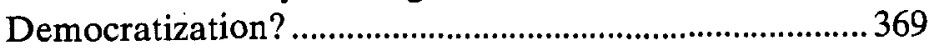

2. Have Efficiency Programs Addressed Capitalization

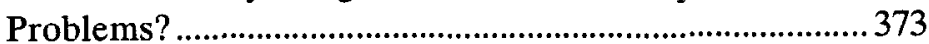

3. Have Efficiency Programs Reduced Costs? ..................... 377

a. Minimizing Compliance Costs ........................................377

b. Minimizing Administrative Costs............................... 379

4. Have Efficiency Programs Created Incentives For Innovation?

5. Have Efficiency Programs Resulted In Improvements In Environmental Quality?

D. How Could We Have Overlooked The Benefits Of Efficiency Programs?

\section{INTRODUCTION}

When former Delaware Governor Pierre du Pont campaigned for the 1988 Republican presidential nomination, he sought to distinguish himself from Democratic hopefuls by characterizing himself as a "piebaker" instead of a "pie-slicer." Democrats such as New York Governor Mario Cuomo and former Vice President Walter Mondale were pieslicers, du Pont said, because they were overly concerned with distribution and "arguing over the angle of the knife slicing the pie," while du Pont claimed to be a pie-baker, someone who would put his "energies into making the pie bigger so that everyone's slice is a little bit bigger." While this is a superficial distinction between Republicans and Democrats, it is an apt distinction between lawyers and economists. Lawyers (including members of the legal academy) are educated and trained as pie-slicers, concerning themselves primarily with questions of fairness and justice, and frequently ignoring questions of efficiency. ${ }^{2}$ This

1. John Dillin, Republican du Pont: Money and a Lot More, ChristIAN SCI. MONITOR, Mar. 11, 1987, at 1.

2. Karl Llewellyn viewed the lawyer's role as making "judgments," and not simply applying general "abstrạct" principles. See, e.g., KARL LLEWELLYN, JURISPRUDENCE: REALISM IN THEORY AND PRACTICE 77-81 (1962); ANTHONY KRONMAN, THE LOST LAWYER 231 (1993) 
is unfortunate because economics is a powerful complement to the law. Economists have also been myopic, still working mostly within a framework that routinely assumes that wealth transfers convert Potentially Pareto Superior policies into Pareto Superior policies, ${ }^{3}$ without paying much attention to whether, in fact, such transfers actually occur. ${ }^{4}$ Rather, the focus of most economic analysis is whether proposed policies maximize group utility or group wealth. ${ }^{5}$ This is the world of piebaking.

While du Pont's metaphor may have been intended to divide Democrats and Republicans, and perhaps "Liberals" and "Conservatives," it can serve a more constructive purpose: to highlight the necessity of having both economists and lawyers involved in policymaking. This is particularly true in environmental law where lawyers have held too much sway, paying too little attention to efficiency. Lawyers have created and perpetuated a system of environmental law that strives to accommodate competing notions of fairness. Regulated

(Practicing lawyers and judges and law professors who share their outlook see their work differently and in particular take a different view of the value of abstraction. In contrast to the lawyer-economist, a practitioner of law 'is not oriented toward finding a simple theoretical structure, economic or otherwise, beneath a 'complex and disorderly jumble of legal rules.' He may note and deplore logical inconsistencies within the jumble, but the idea that it might conceal an inner, and simple, economic logic is unlikely to occur or to appeal to him, and the proposal of such an idea may strike him as 'pretentious and immodest.')

see also Arthur Allen Leff, Economic Analysis of Law: Some Realism about Nominalism, 60 VA. L. REV. 451, 458 (1974) (critiquing Richard Posner's casebook, Economic Analysis of Law, as being normatively empty and circular: "if human desire is made definitionally identical with certain human acts, then those human acts are also beyond criticism in normative or efficiency terms; everyone is doing as best he can exactly what he set out to do which, by definition, is 'good' for him."); James Boyd White, Economics and Law: Two Cultures in Tension, 54 TENN. L. REV. 161, 164 (1986) ("[W]e should not accept the invitation to convert our legal culture-or at a more general level our political culture -into an economic one, as many urge, but vigorously resist it."); Michael A. Livingston, Reinventing Tax Scholarship: Lawyers, Economists, and the Role of the Legal Academy, 83 CORNELL L. REV. 365, 366-67 (1998) (arguing that legal scholars should avoid the adoption of nonlegal subjects in their scholarship).

3. A Pareto Superior policy (sometimes called Pareto optimal or Pareto efficient) is one in which at least one member of society is made better off, and none are made worse off. A Potentially Pareto Superior policy is one in which those that benefit from the policy"winners" - can compensate those that are worse off - "losers" - so that the end result is a Pareto Superior policy. The compensation scheme does not have to be implemented, however; Potential Pareto Superiority only requires that such a compensation scheme exist. See ANDREU Mas-COlell et AL., MiCroeconomic THEORY 311, 313 (1995).

4. Economist David Ricardo warned that even the modest redistributive effects of England's poor laws were destined to "change wealth and power into misery and weakness." Economics Focus: Taxing the Poor to Pay the Poor, ECONOMIST, Apr. 3, 2004, at 80.

5. Economic analysis obviously concerns itself with allocative decisions, but the criteria for making the decisions are still rooted in efficiency. For example, the notion of allocative efficiency is normative in the sense that some allocations are unambiguously superior to others This could be because the superior allocation is Pareto Superior to the inferior one. 
industries insist that environmental regulations are unfairly stringent, ${ }^{6}$ while environmental advocacy organizations insist that they are too weak, and therefore unfair to the general public.

These fairness disputes can never be truly resolved because the concept of fairness is too imprecise to serve as the sole basis for resolving environmental disputes. Consequently, environmental disputes are resolved by giving each interest group a concession. We thus settle for imposing upon polluters a token pound of flesh, requiring them to install some pollution control equipment or otherwise somehow "do their best," while allowing them to essentially carry on their business. We find what appear to be fair outcomes. But too often, we do not ask if the mandated pollution control equipment is the most effective way to reduce pollution, and we almost never ask the very hard question of whether this particular business should be in business at all. What fairness-thinking has wrought is a culture that requires a genuflection to each stakeholder, but fails to identify sensible solutions. In so failing, we have neglected the public interest. An efficiency orientation can help redirect attention towards the public interest, and towards future generatio:s, which are poorly represented in a fairness-dominated political process.

This fairness orientation has also created an enormously complicated maze of statutes and regulations that do not necessarily protect the public or our ecosystems as much as they protect a byzantine system of concessions. The Clean Air Act and Clean Water Act both require the EPA to establish pollution standards that are not only pollutant-specific, but also facility type-specific. ${ }^{7}$ Regulations under the Clean Air Act governing the emissions of nitrogen oxides from coal-fired power plants specify a different emissions standard for each of six different types of coal-fired power plants, from "tangentially-fired" to "vertically-fired" to "dry-bottom wall-fired" to "wet-bottom." This technology-specific

6. In 1990, as Congress marked up the Clean Air Act Amendments that would require the development of a reformulated and less-polluting gasoline, oil companies objected that is was unfair to require them to produce a gasoline product that was not yet technologically feasible. Days after Congress resisted the industry's entreaties to abstain from passing the new requirement, Amoco sold that new gasoline on Pennsylvania Avenue just blocks from the Capitol. Bush Signs Clean Air Act Amendments, Predicts Benefits For All U.S. Citizens, ENV'T REP., Nov. 23, 1990, at 1387.

7. Section 301(b)(2)(A) of the Clean Water Act provides that the EPA is to establish standards for effluent discharges for "point source" polluters that "shall require application of the best available technology economically achievable for such category or class." 33 U.S.C. $\S$ 1311(b)(2)(A) (2003). This meant the development of standards for over two hundred different types of point sources for different pollutants. ROBERT V. PERCIVAL, ET AL., ENVIRONMENTAL Regulation: Law, SCIEnCE, AND POlicy 682 (3d ed. 2000). Predictably, EPA's failure to develop standards at a sufficient pace prompted a lawsuit. Section 112(d)(1) of the Clean Air Act requires the EPA to establish emissions standards for a list of almost two hundred hazardous air pollutants, "for each category or subcategory of major sources and area sources," a similarly burdensome administrative task. See 42 U.S.C. $\$ 7412$ (b) \& (d)(1) (2003).

8. 40 C.F.R. $\$ \$ 76.5-76.7$ (1996). 
approach is the product of an attempt to treat each plant fairly, and to make each plant do its best in terms of emissions reduction. ${ }^{9}$ Nearly lost in the tortured effort, in the name of fairness, to tailor every regulation to every type of situation is the focus on the environment. Despite the traditional (and mistaken) typecasting of economists as enemies of the environment, ${ }^{10} \mathrm{I}$ argue that more economics and more efficiency-thinking can refocus environmental law on the environment.

9. The fairness orientation of this complicated set of regulations is discussed in the text accompanying note 235 , and the political wrangling described in note 235 .

10. See, e.g., DAVID BroWER, THE SERMON (1993) ("I quote Hazel Henderson: 'Economics is a form of brain damage.' .... Economists are in trouble because they leave out of their calculations two terribly important factors, which they name and do nothing about: the cost to the Earth and the cost to the future."). However much human energy and ingenuity we expend, if we don't have some natural resources to manipulate and fashion for our needs, then we are not only poor, but dead. Economists seem sometimes to doubt this, particularly the technological optimists who sometimes give the impression that the human mind can engineer infinite substitution as resources become scarce. HAZEL HENDERSON, CREATING ALTERNATIVE FUTURES: THE END OF ECONOMICS 93 (1996)

The debate now shaping up between economics versus long-term environmental ethics has been brewing for over a decade. Economists whose intellectual investments and clients are tied to the declining sector have been lobbying environmentalists and insisting that it is we who need to learn economics, rather than they that need to learn ecology and systems sciences.

HAZEL HENDERSON PARADIGMS IN PROGRESS: LIFE BEYOND ECONOMICS 97 (1995)

Let's assume, for the duration of this article, that to you trees are vertical stalks of fiber, that a forest carries no more spiritual or aesthetic value than a parking lot, that woodland creatures are uninteresting sacks of calories, and that the smell of sunbaked pine needles on a breezy June afternoon merely matches the scent that comes from those conifer-shaped air fresheners that dangle from your rearview mirror. Let's assume, in other words, that you've done something rotten and God has turned you into an economist.

Bill McKibben, What Good Is a Forest? AUDUBon, May/June, 1996, at 54 The widely-known Canadian environmental activist David Suzuki has also sounded off on the pernicious effects of the dismal science:

Perhaps the most destructive agent of our sense of interconnectedness is cconomics. Economists assume that when resources are exhausted, human intelligence and creativity will always enable us to exploit or create new materials. Thus, in conventional economics, the ozone layer, underground water aquifers, topsoil, or biodiversity are considered 'externalities' that are irrelevant within the economic construct, even though these are all finite and crucial to human survival and health.

David Suzuki, Time to Rediscover Our Place in Nature, CNEWS, Apr. 23, 2003, at http://www.canoe.ca /CNEWSScience0207/030423_suzuki-can.html. Also:

Well, I certainly think economics is at the heart of the current crisis affecting the planet. And I think the fact that every government on earth seems to have bought into the current idea of economics virtually assures that we will continue at the same destructive rate. The whole drive for GATT agreements, for greater free trade and globalization of the marketplace absolutely assures that we're going to destroy the planet. And the reason is because economics-the way it's been constructed-is not connected to the real world.

Interview by Nancho Ijin Butai with David Suzuki (1999), at http://www.nancho.net/advisors/ suzuki.html\#toc. 
In calling for more efficiency-thinking, I do not argue for an abandonment of fairness considerations, or even for supremacy of efficiency over fairness. ${ }^{11}$ Rather, I argue for a greater willingness to explicitly consider the tradeoffs inherent in environmental decision making, and a greater willingness to think of these tradeoffs in quantitative terms. The rough magnitude of societal gains and losses resulting from environmental proposals must be discussed, even if it seems crass to do so, and even if it is not the deciding factor for any given environmental proposal. Obsession with fairness and a refusal to expressly consider costs and benefits has blunted our sense of perspective, particularly since our model of legal advocacy rewards those who are most proficient at developing the most self-serving arguments.

Importantly, a call for more efficiency-thinking is not merely a call for more cost-benefit analysis. Fundamentally, a shift towards efficiencythinking means placing a greater emphasis on increasing total welfare than on upholding individual rights. This re-orientation of thinking might require difficult choices to be made, such as the choice of whether or not to impose a large welfare loss on a small group for the sake of conferring a small welfare gain on a large group. This is the kind of difficult decision that we must face if we consider, for example, whether we should impose logging restrictions for the sake of ecological preservation, even if doing so would deprive loggers of jobs. Avoiding these difficult decisions, however, has been a great failure of our environmental law and policymakers.

One might argue that efficiency has already become an important driver in environmental law and policy. ${ }^{12}$ Cost-benefit analyses, for

11. Daniel Farber is the architect of Eco-pragmatism, a philosophy of environmental decision making that similarly endorses taking into account cost-benefit analysis, but without making it determinative. Farber, however, builds in other principles, including an "environmental baseline" - a presumption in favor of environmental protection, the use of low discount rates in analysis, and generally a feasibility approach to regulation. DANIEL $A$. FARBER, ECO-PRAGMATISM: MAKING SENSIBLE ENVIRONMENTAL DECISIONS IN AN UNCERTAIN WORLD 9-12, 201-02 (2001).

12. David Driesen has argued this in his new book. DAVID M. DRIESEN, THE ECONOMIC DYNAMICS OF ENVIRONMENTAL LAW 1-3 (2003). Jonathan Wiener believes that there is a "virtual consensus" of legal scholars that favor efficiency-based approaches. Jonathan Baert Wiener, Global Environmental Regulation: Instrument Choice in Legal Context, 108 YALE L. J. 677,714 (1999). However, there remains a substantial number, and perhaps still a majority, of legal scholars that oppose efficiency-based or incentive-based environmental policy instruments. See, e.g., Sidney A. Shapiro \& Robert L. Glicksman, Risk Regulation AT Risk: Restoring a PRAGMATIC APPROACH (2003); David M. Driesen, Is Emissions Trading an Economic Incentive Program?: Replacing the Command and Control / Economic Incentive Dichotomy, 55 WASH. \& LEE L. REV. 289 (1998); Lisa Heinzerling, The Rights of Statistical People, 24 HARV. ENVTL. L. REV. 189 (2000); Thomas O. McGarity, Professor Sunstein's Fuzzy Math, 90 GEO. L.J. 2341 (2002). For an efficiency argument against efficiency-based approaches and for command and control schemes, see Daniel H. Cole \& Peter Z. Grossman, When Is 
example, have long been required for regulations that meet some threshold level of economic impact. ${ }^{13}$ The appointment of John Graham, an economist and advocate of cost-benefit analysis, to a key post in the Office of Management and Budget has led to the increased use of costbenefit analysis in risk and environmental regulation. ${ }^{14}$ But the increased use of cost-benefit analysis in rulemaking has not cured and cannot cure environmental law of its more fundamental problem: it is still a repository for self-serving arguments and for disputes over fairness, the resolution of which often cannot be rationally accomplished without resort to more objective means of analysis. For this to change, debates must be argued differently, disputes must be resolved differently, and statutes must be written differently. Administrative agencies, caught in the crossfire between regulated industries, environmental organizations, and dozens of other stakeholders, ${ }^{15}$ have increasingly recognized this. But political actors such as the United States Congress and the critical stakeholders that help to write the statutes have not. They remain stuck in fairnessthinking mode. Statutes remain fairly circumscribed in their reliance on cost-benefit analysis, ${ }^{16}$ and are carefully tailored to mollify as many special interests as possible. ${ }^{17}$

The most pragmatic justification for adopting more efficiencythinking may be that fairness-thinking has locked us into a legislative stalemate. Over the first twenty years of environmental law, the Clean Air Act, the Clean Water Act, and other statutes have produced

Command-and-Control Efficient? Institutions, Technology, and the Comparative Efficiency of Alternative Regulatory Regimes for Environmental Protection, 1999 WIS. L. REV. 887 (1999).

13. President Reagan first imposed a requirement that a cost-benefit analysis be performed for any proposed regulation that would have an economic impact greater than $\$ 100$ million. Exec. Order No. 12,291, 46 Fed. Reg. 13,193 (Feb. 17, 1981). This policy has been continued, up through the Clinton administration, which modified the requirement but did not abandon costbenefit analysis. Exec. Order No. 12,866, 58 Fed. Reg. 51,735 (Sept. 4, 1993).

14. Rena I. Steinzor, Pragmatic Regulation in Dangerous Times Risk, 20 YALE J. ON REG. 407,416 (2003).

15. It is perfectly rational for Congress to pass "symbolic" legislation to burnish its environmental credentials, while leaving to the administrative agencies the impossible task of carrying out the programs. John P. Dwyer, The Pathology of Symbolic Legislation, 17 ECOLOGY L.Q. 233, 233 (1990).

16. Congress on several occasions in the 1990s rejected cost-benefit requirements attached to environmental standard-setting statutes. See infra text accompanying note 410 . The proposed amendments would have established cost-benefit tests as a "decision rule" that would trump all other concerns. These proposals would have gone too far, but are indicative of Congress's suspicion of cost-benefit analysis. See also SHAPIRO \& GLICKSMAN, supra note 12, at 32-44 (noting that most risk regulation statutes contemplate a fairly modest role for cost-benefit analysis).

17. For example, although the Clean Air Act Amendments represented a breakthrough in efficiency-oriented environmental regulation, they still contained a variety of dispensations for special interests. See infra text accompanying notes $298-300$. 
enormous environmental benefits at relatively modest $\operatorname{cost},{ }^{18}$ making it possible to accommodate both regulated entities and environmental organizations and their views of fairness. In more recent years, however, with much of the low-hanging fruit already picked, environmental progress has reached a plateau, and neither side has been able to sustain a coalition sufficient to advance its own views of fairness. ${ }^{19}$ Fairnessthinking has sharply polarized environmental stakeholders and has obscured many of the possibilities for productive policy change. ${ }^{20}$ In the meantime, more than a decade has passed without any significant federal environmental legislation, ${ }^{21}$ pollution problems that have been with us for decades continue to claim human lives and harm human health

18. Since the passage of the Clean Air Act in 1970, emissions of the six primary air pollutants have been reduced by twenty-five percent, even as Gross Domestic Product, energy consumption, vehicle miles traveled, and U.S. population grew. Air Pollution: Testimony by EPA Administrator Whitman Clear Skies Legislation (S. 85) Before Senate Environment and Public Works Clean Air Subcommittee, 34 ENV'T REP., Apr. 11, 2003, at 843. Daniel Farber has noted that emissions of air pollutants have declined or remained constant even as economic growth and automobile usage have increased dramatically. Daniel A. Farber, Environmental Protection As A Learning Experience, 27 LOY. L.A. L. REV. 791, 793-94 (1994). Nationwide, emissions of toxic chemicals have declined from 10.4 billion pounds in 1987 to just under 2.6 billion pounds in 1997, a seventy-five percent decrease. See PERCIVAL, supra note 7, at 378. Waters that are safe for fishing or swimming in the U.S. have doubled since the passage of the Clean Water Act. EPA, WATER POLlution CoNTrol: 25 Years of Progress AND CHALLENGES FOR THE NEW MILLENIUM 1 (1998), available at http://cfpub1.epa.gov/npdes/ doctype.cfm?sort=name. In 1998, sixty to seventy percent of all waters met state water quality goals, as opposed to thirty to forty percent in 1972. CLEANWATER.GOV, CLEAN WATER ACTION Plan: CleAN WATER SUCCESSES AND CHALlenges, available at http://cleanwater.gov/action/cla.html (last updated Aug. 10, 1998). Notoriously polluted waterbodies such as Boston Harbor, Lake Erie, the Connecticut River, the Willamette River in Oregon, and the Cuyahoga River have experienced water quality improvements. See PERCIVAL, supra note 7 , at 625 . Nationwide emissions of sulfur dioxide, particulate matter, and volatile organic compounds have declined since the mid-1970s. EPA, NATIONAL AIR POLLUTANT EMISSION TRENDS, 1900-1998 ES-5 (2000), available at http://www.epa.gov/ttn/chief/ trends/trends98/trends98.pdf. Emissions of lead declined dramatically during that period, due mostly to a phase-out of leaded gasoline. See id.at 3-15 tbl.3-7; $c f$. Kenneth A. Manaster, Ten Paradoxes of Environmental Law, 27 LOY. L.A. L. REV. 917, 917-918, n.4 (1994).

19. An evenly divided Congress for the past decade has failed to either enact significant new environmental legislation or make significant amendments, for better or for worse. Joel A. Mintz, The Clean Water Act TMDL Program: Law, Policy and Implementation, by Oliver A. Houck, 26 Colum. J. EnVTL. L. 213, 217 (2001); Rena I. Steinzor, You Just Don't Understand!The Right and Left in Conversation, 32 ENVTL. L. ReP. 11109, 11109 n. 5 (2002); Ann R. Klee \& Ernie Rosenberg, The Moribund State of CERCLA Reauthorization, 13 NAT. RES. \& ENV'T 451, 451 (1999). Numerous amendments have been proposed to the controversial and troubled Endangered Species Act, but none have passed. Shi-Ling Hsu, The Potential and Pitfalls of Habitat Conservation Planning Under the Endangered Species Act, 29 ENVTL. L. REP. 10592, 10595, n.33-37 (Oct. 1999).

20. This polarization has been aptly likened to "tribalism." Douglas A. Kysar and James Salzman, Environmental Tribalism, 87 MINN. L. REV. 1099 (2003).

21. This author considers the last significant piece of environmental legislation to have been the 1990 Clean Air Act Amendments. In the thirteen years since its passage, Congress has tinkered little with environmental statutes. See supra note 19. 
needlessly, and quite possibly our most important new challenges-global climate change and species extinction - remain woefully unaddressed.

Louis Kaplow and Steven Shavell have taken up the question of fairness versus efficiency in more general terms in their book, Fairness Versus Welfare. In it, they argue that the concept of fairness is inherently susceptible to multiple interpretations, and that this renders fairness fatally flawed as a decisionmaking criterion. ${ }^{22}$ The only rational criterion for decisionmaking, they argue, is welfare maximization. ${ }^{23}$ Their quest to infuse the legal academy with efficiency-thinking has met with resistance, led by Daniel Farber and Richard Fallon, ${ }^{24}$ who have written on the shortcomings of the strong form of welfarism ${ }^{25}$ advocated by Kaplow and Shavell. ${ }^{26}$ I do not seek to participate in this heady debate. As noted above, I do not argue that efficiency should trump fairness concerns in all cases, nor do I need to in order to identify critically important improvements in environmental law that are efficiency-based.

Part I of this Article explores some conceptions of fairness as manifested in environmental law and policymaking. Part II of this Article discusses the problems with using fairness as a rhetorical tool for making environmental law and policy. Part III discusses the notion of efficiency, and how it both resembles and differs from notions of fairness. Part IV discusses ways in which efficiency-thinking may overcome some of the problems posed by fairness-thinking, and as well as some fairness-created pathologies seemingly embedded in environmental law and policy. This part lays out my normative argument for more efficiency-thinking and less fairness-thinking. Part $\mathrm{V}$ discusses several examples of fairnessdriven and efficiency-driven environmental law. I show how

22. LOUIS KAPLOW \& STEVEN SHAVELl, FAIRNESS VerSUS WELFARE 45-51 (2002).

23. Id. at 52-58. Kaplow and Shavell advocate a "welfare-based normative approach," using a broad definition of human welfare, which takes into account "not only individuals' levels of material comfort, but also their degree of aesthetic fulfillment, their feelings for others, and anything else they might value, however intangible." $I d$. at 3-4. This broad notion of welfare would even include individuals' preferences for having legal outcomes that are deemed "fair." Id. at 21 .

24. Daniel A. Farber, What (If Anything) Can Economics Say About Equity? 101 MICH. L. Rev. 1791 (2003); Daniel A. Farber, The Problematics of the Pareto Principle, U.C. Berkeley School of Law Public Law and Legal Theory Research Paper No. 114, 2003, at http://www.ssrn.com/

abstract_id=384142; Richard H. Fallon, Jr., Should We All Be Welfare Economists? 101 MICH. L. REV. 979 (2003).

25. Welfarism is generally considered a variant of utilitarianism which posits a social welfare function with social utility as its index. Howard F. Chang, A Liberal Theory of Social Welfare: Fairness, Utility, and the Pareto Principle, 110 YALE L.J. 173, 176 (2000).

26. Even Richard Posner does not adopt the strong welfarist approach that Kaplow and Shavell advocate. See RICHARD A. POSNER, ECONOMIC ANALYSIS OF LAw 397 (2003) ("But when cost-benefit analysis is merely an input into decision, there is no need to insist on its adequacy as a normative principle, provided that wealth is accepted to be $a$ social value, even if not the only one."). 
considerations of fairness or efficiency motivate provisions and discuss whether efficiency programs actually resulted in any environmental or economic benefits. In Part VI, I make two modest proposals: first, for the passage of legislation mandating cost-benefit analyses, without coupling the analyses to any substantive regulatory results; and second, for the use of per-unit pollution taxes, or "Pigouvian" taxes. Finally, Part VII concludes by appealing to pie-slicers to reconsider pie-baking as a way to help resolve the intractable disputes that presently characterize environmental law.

\section{WHAT IS FAIRNESS IN ENVIRONMENTAL LAW?}

With so much written throughout the history of humankind on notions of fairness, ${ }^{27}$ this Article can only touch upon those conceptions that have special relevance to environmental law. While Kaplow and Shavell attack fairness in more general terms, I seek to show that in its application to environmental law, fairness is subject to multiple definitions and is therefore incoherent as applied. This section briefly discusses some of the versions of fairness that have shaped environmental law. I do not intend the following discussion to be taken as an exposition on the general influence of fairness notions on the law.

\section{A. Fairness As The Equal Distribution Of Burdens And Benefits}

Perhaps the most familiar notion of fairness pertains to equality. ${ }^{28}$ In environmental law, it often takes the form of a sense that the burdens and benefits of environmental protection should be distributed equally among all polluters and all members of the public. ${ }^{29}$ This notion has been pervasive in environmental law, not so much as a tool for engineering social change, but for ensuring that the burdens of environmental problems are distributed equally.

The Environmental Justice movement has sought to vindicate the rights of socio-economically disadvantaged communities that bear a

27. "Justice" is a term often discussed along with fairness, although fairness and justice are not considered synonymous in the philosophy and political philosophy literature. John Chapman has argued that fairness is really an expression of the norm of reciprocity, and pertains to processes, while justice implies a finality or an outcome. Thus, we say that trials are fair or unfair, while we say that outcomes are just or unjust. John W. Chapman, Justice and Fairness, in JUSTICE 154-60 (Carl J. Friedrich \& John W. Chapman eds., 1963). But John Rawls has argued that justice is fairness, which can bc largely described as "right dealing between persons." John Rawls, Justice as Fairness, 67 PHIL. REV. 164, 178 (1958).

28. This version of fairness, as I conceive of its application in environmental law, is most like versions of "distributive justice" first attributed to Aristotle. See NiCOMACHEAN ETHICS OF ARISTOTLE: BOOK V 114-17 (Oxford Univ. Press 1975).

29. See Christopher Ake, Equality As Justice, 5 PHIL. \& PUBL. AfF. 69, 71 (1975) (arguing that justice is too malleable a concept to form a fundamental principle, and that it is thus best defined in terms of equality, in the sharing of overall burdens and benefits). 
disproportionate share of environmental risk. ${ }^{30}$ Widespread recognition of the need to address these inequities resulted in the promulgation of Executive Order $12,898,{ }^{31}$ which requires federal agencies to ensure that their actions do not disproportionately affect disadvantaged communities. What makes environmental justice concerns so compelling is the strong sense of unfairness that arises when certain communities systematically suffer a higher environmental risk than others. The idea that some of our citizens bear more than a "fair" share of risk has proven to be deeply offensive to our notions of equality.

This notion of fairness also animates concerns for how regulated parties are treated under environmental law. Environmental laws are dotted with provisions that ensure equal treatment for regulated parties that are similarly situated. For example, water pollution regulations under the Clean Water Act must treat facilities of a similar type similarly. ${ }^{32}$ It is also due to this notion of fairness that regulation specifically affecting or targeting a particular industry is met with stiff opposition, especially if the industry feels that it has been singled out. For example, tightening of automobile emissions standards and fuelefficiency standards have been consistently and vigorously opposed by American automakers on the grounds that automobiles represent only a portion of the air pollution problem (and thus should not shoulder a larger portion of the pollution reduction burden), ${ }^{33}$ and that the automotive industry has already done enough to reduce pollution. ${ }^{34}$ They

30. Tseming Yang, Melding Civil Rights and Environmentalism: Finding Environmental Justice's Place in Environmental Regulation, 26 HARV. ENVTL. L. REV. 1, 4-8 (2002); Vicki Been, What's Fairness Got To Do With It? Environmental Justice and the Siting of Locally Undesirable Land Uses, 78 CORNELL L. Rev. 1001, 1029 (1993); Alice Kaswan, Distributive Justice and the Environment, 81 N.C. L. REV. 1031, 1043-44 (2003).

31. 59 Fed. Reg. 7,629 (1994).

32. See infra text accompanying note 236. The Clean Water Act also provides facilities with an opportunity to show that they are "fundamentally different" from other facilities with which they are grouped. Clean Water Act $\$ 301(n), 33$ U.S.C. $\$ 1311(n)$ (2003).

33. The validity of this claim depends upon the pollutant. In 1998, fifty-three percent of the emissions of nitrogen oxides (NOx) was attributable to vehicles and non-road engines, twentyfiver percent to electricity generation; nineteen percent of the emissions of particulate matter was attributable to vehicles and non-road engines, eight percent to electricity generation; seven percent of sulfur dioxide emissions was attributable to vehicles and non-road engines, sixtyseven percent to electricity generation. EPA, NATIONAL AIR POLLUTANT EMISSION TRENDS, 1900-1998, supra note 18, at 2-10 fig.2-2, 2-12 fig.2-4, 2-13 fig.2-5.

34. Allan R. Gold, Senators to Offer Own Clean Air Bill, N.Y. TIMEs, Sept. 15, 1989, at A24 ("Among Mr. Dingell's constituents are auto makers in Detroit. Mr. Dingell said today that auto makers and other car-related industries should not be singled out in any new clean air legislation."); Gary Bryner, Blue Skies, Green Politics: The Clean Air ACt of 1990, at 98 (1993). At the same time, representatives from congressional districts that had coal-fired power plants were equally adamant that they had done their fair share in reducing pollution, and that any further restrictions would be unfair to them. See id. at 99. But see Paul D. Brown, Lofty Goals, Questioned Motives, and Proffered Justifications: Regional Transport of Ground-Level Ozone and the EPA's NOx SIP Call, 60 U. PITT. L. REV. 923, 963 (1999) ("The electric utility 
have found ready support from Michigan's Congressional delegation, even Democrats that have otherwise been viewed as environmentalists. ${ }^{35}$ This particular sense of fairness can even create divisions within an industry, creating rifts between electric utility companies that own highlypolluting coal-fired power plants and those that own less-polluting natural gas-fired power plants. Northeastern utilities that have already switched from coal-fired power plants to cleaner-burning natural gas feel that they have done their part to address the acid rain problem that coal combustion has created in the entire Eastern United States. These utilities resent the fact that their Midwestern counterparts have failed to follow suit, and in their view, have not done their part to reduce the regional acid rain problem. ${ }^{36}$ Again, it is a sense of equality that is offended when one group or region is asked to bear more than its fair share of an environmental burden.

This notion of fairness also applies to situations in which some parties feel they are competing on an uneven playing field. It is, in a sense, an unequal distribution of burdens and benefits to subject some parties to a disadvantage vis-à-vis others in a competitive market. American automakers, which have traditionally made less fuel-efficient cars, moan that tightening fuel-efficiency requirements would unfairly impose upon them a competitive disadvantage vis-à-vis Japanese automakers such as Honda and Toyota, that produce more fuel-efficient vehicles. $^{37}$

This conception of fairness is a powerful one, helping to create regional alliances among those not ordinarily in agreement with one

industry as a whole has not kept pace with pollution reductions by other industries that emit NOx and VOCs; within the electricity utility industry, the midwest has not pulled its weight when it comes to NOx reductions."); Utilities Not Doing Enough to Protect Public Health, EPA's Nichols Declares, UTIL. ENV'T. REP., Nov. 8, 1996, at 1 ("While mobile sources-such as cars, light-duty trucks and heavy-duty vehicles-have made 'major contributions' to the public health by achieving emissions reductions ranging from $70-90 \%$, stationary sources such as utility generating plants have only ratcheted emissions down some $30-40 \%$."); Electric utilities have sometimes pushed for the introduction of electric vehicles, much to the consternation of automakers. Michael Parrish, Driving Force Behind Electric Utilities Take on Detroit in Defending Green Rules, L.A. TIMES, Nov. 23, 1993, at D1.

35. Deborah Stabenow was elected to the Senate in 2000 with the help of the League of Conservation Voters (LCV), an advocacy organization that aids candidates running on environmental platforms. Generally hailed as a "pro-environment" senator (a $71 \%$ rating by LCV in $2002,100 \%$ in 2001 , LEAGUE OF CONSERVATION VOTERS, NATIONAL ENVIRONMENTAL SCORECARD (2002), available at $\mathrm{http}: / / 207.188 .212 .113 / \mathrm{scorecard} / \mathrm{scorecardList.cfm}$ ?c=25. Stabenow nevertheless helped defeat a Senate measure to raise automobile fuel efficiency standards. Stabenow was joined by her Democratic Michigan colleague Carl Levin (LCV rating 65\% for 2002, 88\% in 2001, id.). See Jeff Plungis, Plan to Raise Fuel Rules Fails, DETROIT NEWS, Mar. 13, 2002, at B1.

36. Acid rain precursors emitted by coal-fired power plants are transmitted over long distances, meaning that the Midwestern power plants are contributing to the acid rain problem in the Northeastern United States. See Brown, supra note 34, at 961-63.

37. See Plungis, supra note 35 . 
another ${ }^{38}$ uniting Republican and Democrat politicians on environmental issues when their shared constituency has been called upon to bear more burdens or enjoy fewer benefits than other regions or groups. ${ }^{39} \mathrm{I}$ refer to this version of fairness as a "distributive" sense of fairness.

\section{B. Fairness As Avoiding Retroactive Regulation}

There is a strong American legal instinct to avoid ex post regulation,,$^{40}$ especially when it affects expensive capital investments. ${ }^{41} \mathrm{We}$ believe it is unfair to impose regulatory burdens that could not have been reasonably foreseen at the time of the investment. This sense of fairness has had a great impact on environmental law, where polluting industries often invest in large, capital-intensive projects. However, scientific

38. Efforts to push through an air pollution reduction bill in the House of Representatives, for example, have created strong bonds between such strange bedfellows as liberal Democrat Henry Waxman and conservative Republican Jerry Lewis, both of whom represent smog-choked districts in the Los Angeles region. RICHARD E. COHEN, WASHINGTON AT WORK 30 (1995). At the same time, fellow Democrats Waxman and John Dingell of Michigan were fierce combatants over clean air legislation:

Dingell was troubled by ... Waxman's ...desire to push his aggressive environmental agenda; to Dingell, who sometimes exaggerated his case, Waxman represented the wealthy and trendy glitterati of Los Angeles's fashionable Rodeo Drive, who drove foreign cars and looked down upon their noses at Dingell's blue-collar voters. Dingell also believed that Waxman's views and his constituents, who thought nothing of driving an hour to work each day, had exacerbated southern California's pollution. Now, even worse, they wanted already distressed Detroit and the rest of the nation to pay the bill to clean up Los Angeles.

Id. at 34; see also Vicky Cahan \& Paula Dwyer, Can Bush, the Democrats, ecologists, and industry hammer out a deal? BUSINESS WEEK, Mar. 5, 1990, at 27 ("The debate is more heated than most business environmentalist contretemps. It pits Detroit carmakers against Texas oil barons, West Virginia coal miners against New England conservationists, and Florida's "clean" utilities against coal-burners in the Midwest.").

39. Republicans from New Hampshire, the "Live Free Or Die" state, have united with Democrats from their archrival state of Vermont, in petitioning the EPA to revisit Clean Air Act requirements for NOx controls under section 126, and to seek the imposition of pollution controls on Midwestern power plants transmitting pollution in the form of acid rain. See Brown, supra note 34, at 946, 957. New England senators have also united in challenging the Bush administration's environmental proposal to eliminate New Source Review. Steve Cook, Enforcement: Two Senators Object to Colleagues' Request to Suspend New Source Review Enforcement, 32 ENV'T REP. 752, Apr. 20, 2001.

40. The Ex Post Facto Clause provides that "No Bill of Attainder or ex post facto Law shall be passed." U.S. CONST., art. I, $\S 9$, cl. 3. Although this has historically been limited to criminal cases, some Supreme Court justices seem to be ready to extend it to more general cases. Eastern Enters. v. Apfel, 524 U.S. 498, 538-39 (1998) (Thomas, J., concurring); see also Daniel E. Troy, Symposium: When Does Retroactivity Cross the Line? Winstar, Eastern Enterprises and Beyond: Toward a Definition and Critique of Retroactivity, 51 ALA. L. REV. 1329, 1330 ("It is no more fair for a parent to impose a penalty to an offense after the offense is committed, than it is for a civil government to pass an ex post facto law, by which punishment is to be awarded for offenses committed before that law was passed.").

41. Justice Brennan's opinion in Penn Central Transportation Co. v. City of New York, 438 U.S. 104 (1978), is the origin of the "investment-backed expectations" line of inquiry in regulatory takings cases. See infra note 226. 
knowledge and environmental circumstances can change rapidly, often warranting some regulatory control over these investments. Instead of requiring changes when new scientific facts indicate that immediate and retroactive regulation is warranted, environmental law has typically grandfathered in existing uses $^{42}$ or provided for a phase-in period. ${ }^{43}$ Notable exceptions, such as the imposition on legally responsible parties of retroactive hazardous waste liability under the Superfund law, ${ }^{44}$ have been extremely controversial. ${ }^{45}$

It is important to note that "capital" is not limited to large, expensive physical assets such as power plants. The impact of regulation on human capital in many forms is also carefully considered when evaluating economic dislocation. For those industries in which human capital exists in the form of labor skills that do not transfer to other occupations-such as logging, mining, or ranching - the imposition of retroactive regulation adversely affecting the value of this human capital is undertaken with great political delicacy. ${ }^{46}$

Whether it is physical or human capital that we treat with such care, our reluctance to impose regulatory burdens is driven by a sense that government should not frustrate reasonable expectations. ${ }^{47} \mathrm{We}$ believe it

42. See Richard Stewart, Controlling Environmental Risks Through Economic Incentives, 13 COLuM. J. ENVTL. L. 153, 158 (1988). For examples of such "grandfathering," see infra text accompanying notes 221-226.

43. The prohibition of the use of lead in gasoline was accomplished by a lead permit trading program. Refiners were given two years to phase out the use of lead in gasoline, but could trade with each other the diminishing rights to include lead. See 40 C.F.R. $\$ 80.20$ (1988); 50 Fed. Reg. 13,116-01 (Apr. 2, 1985). In ratifying the Montreal Protocol to eliminate the use of ozone-depleting chemicals, the United States adopted a phase-out of the use of such chemicals. 53 Fed. Reg. 30,566 (Aug. 12, 1988).

44. Comprehensive Environmental Response, Compensation, and Liability Act of 1980, 42 U.S.C. $\$ \$ 9601-9675$ ("CERCLA"). Liability under CERCLA is retroactive. United States v. Olin Corp. 107 F.3d 1506, 1511-12 (11th Cir. 1997); Va. Prop., Inc. v. Home Ins. Co. 74 F.3d 1131, 1132 (11th Cir. 1996).

45. See PerCival, supra note 7 at 326-328.

46. Regulation that may result in the loss of jobs has often been coupled with special dispensations to aid displaced workers. The Clean Air Act Amendments introduced emissions trading for sulfur dioxide. See infra text accompanying notes 257-261. As a special dispensation for the coal mining industry, bonus emissions allowances were awarded to firms that installed expensive "scrubber" technology that would enable them to continue to use the high-sulfur coal mined in Senator Robert Byrd's West Virginia. The allowances amounted to a subsidy of those utilizing the higher-sulfur content coal. Even this was a compromise, resulting from an earlier attempt by Byrd to include a proposal in the amendments to guarantee coal miners losing their jobs to three years of more than half of their salary and benefits, at an estimated cost of half a billion dollars. COHEN, supra note 34 at 108-12. The battle was indicative of the fragility of coalitions built on fairness considerations, as environmental groups ordinarily sympathetic to labor interests found themselves split over the Byrd proposal ("What was a matter of fairness to the unions, however, seemed like a very bad idea to other parts of the clean-air coalition.").

47. While this version of fairness appears to present a tension with the distributive sense of fairness, it can be argued that the two versions are not different at all. Ronald Dworkin has argued for a conception of equality as an equality of resources, considered over a lifetime. Thus, Dworkin would allow someone who was diligent in earlier years to keep the spoils of her hard 
is unfair to change the rules of the game after one has undertaken some investment under one set of rules. I refer to this version of fairness as an "expectations" sense of fairness. ${ }^{48}$

\section{Fairness In The Retributive Sense}

Along with an increasing awareness and stronger scientific evidence of the public health effects of environmental problems has come a sense that polluting is wrongful or immoral behavior. ${ }^{49}$ From that notion, it is only a short step to the conclusion that some of the underpinnings of criminal law should also be applicable to environmental law, including the notion of "retributive justice," the notion that wrongdoers should be punished. ${ }^{51}$ Curiously enough, even though environmental law has its roots in tort law, ${ }^{52}$ it has not embraced the tort notion that compensation should be paid to victims of wrongful acts. ${ }^{53}$ Virtually every

work, even if it resulted in some inequality later. This notion of equality would thus protect investment expectations, and prevent a later redistribution that would frustrate such expectations. See Ronald Dworkin, What Is Equality? Part 2: Equality of Resources, 10 PHIL. \& PUBL. AFF. 283, 307 (1981).

It is also possible, however, to argue that our sense of expectations arises out of a Lockean sense of justice, which places the protection of property at the heart of an ordered society. Locke wrote: "The great and chief end ... of [government] is the preservation of their property." JOHN Locke, Second TReatise On Government 71 (Thomas P. Peardon ed., Liberal Arts Press 1952) ( $\$ 124$ ). Together with Locke's argument that one acquires property by mixing in one's labor, and given Locke's influence on the framers of the Constitution, one can make the argument for strong protection of investment-backed expectations. For discussions on the influence of the Lockean conception of property rights, see Myrl L. Duncan, Property As A Public Conversation, Not a Lockean Soliloquy: A Role for Intellectual and Legal History in Takings Analysis, 26 ENVTL. L. 1095 (1996), and Myrl L. Duncan, Reconceiving the Bundle of Sticks: Land As a Community-based Resource, 32 ENVTL. L. 773 (2002). The Supreme Court has even invoked Locke in finding that a land use regulation required compensation under the takings clause of the Fifth Amendment of the Constitution: "The State may not put so potent a Hobbesian stick into the Lockean bundle." Palazollo v. Rhode Island, 533 U.S. 606, 627 (2001).

48. See infra note 226.

49. David B. Spence, Paradox Lost: Logic, Morality, and the Foundations of Environmental Law in the 21st Century, 20 Colum. J. ENVTL. L. 145, 145-46 (1995). For an example of scholarship arguing for a morality-based environmental regulatory framework, see, for example, Thomas R. Mounteer, The Inherent Worthiness of the Struggle: the Emergence of Mandatory Environmental Planning as an Environmental Regulatory Ethic, 19 COLUM. J. ENVTL. L. 251 (1994).

50. Kaplow and Shavell use the phrase "retributive justice" to describe a widely-held social norm that people should be punished for acts deemed to be wrongful. KAPLOW \& SHAVELL, supra note 22 , at 9 .

51. The four goals of criminal law are retribution, deterrence, rehabilitation, and incapacitation. See WAYNE R. LAFAVE \& AUSTIN W. SCOTT, JR., SUBSTANTIVE CRIMINAL LAW 35-42 (1986); SANFORd H. KaDish \& STEPHEN J. SCHUlhofer, CRIMINAL LAW AND ITS PROCESSES 97-167 (6th ed. 1995).

52. See, e.g., Percival, supra note 7, at 72-77.

53. See, e.g., W. PAGE KeETON, ET AL., 1 Prosser AND KeEton AND THE LAw OF TORTS 20 (5th ed. 1984) ("It is sometimes said that compensation for losses is the primary function of tort law and the primary factor influencing its development."). The tort law concept that victims 
environmental statute contains retributive provisions that impose criminal and civil fines based on individual acts or a series of acts, ${ }^{54}$ while few contain compensatory provisions that contemplate the payment based upon the extent of damage..$^{55}$

The nature and structure of these penalty provisions reinforce the conclusion that much environmental law was written with retributive principles in mind, rather than compensatory principles, since the penalties are often keyed to the degree of fault, not to the amount of damage caused. For example, under the criminal provisions of the Clean Water Act, ${ }^{56}$ a negligent violation warrants fines of $\$ 2,500$ to $\$ 25,000$ per day of violation, or prison terms of up to one year, or both; $;{ }^{57}$ a "knowing" violation warrants fines of $\$ 5,000$ to $\$ 50,000$ per day, or prison terms of up to three years, or both..$^{58}$ Both of these sanctions double for a second such violation. ${ }^{59}$ Worst of all, however, a "knowing endangerment" of another of "imminent danger of death or serious bodily injury" warrants fines of up to $\$ 250,000$, or a prison term of up to fifteen years, or both. ${ }^{60}$ Other statutes contain similar penalty structures. ${ }^{61}$ It is possible that the

should be compensated is a fairness notion. But compensation and the criminal law concept of retribution are really two halves of Aristotle's notion of "corrective justice." See NICOMACHEAN ETHICS, supra note 28, at 114-17; KAPLOW \& SHAVELL, supra note 22, at 86-90; Jules Coleman, The Practice of Corrective Justice, 37 ARIZ. L. REV. 15, 15 (1995). Corrective justice requires not only that the victim be compensated, but also that the wrongdoer, or "assailant," be disgorged of the fruits of her wrongdoing. See NICOMACHEAN ETHICS, supra note 28, at 114-17

54. Criminal and administrative penalties are contained in Endangered Species Act $\S$ 11(b), 16 U.S.C. $\$ 1540$ (b) (2003); Federal Water Pollution Control Act $\$ 309$ (c), 33 U.S.C. \& 1319(c) (2003); Clean Air Act $\$ 205$ (c), 42 U.S.C. $\$ 7524$ (c) (2003) (pertaining to violations of emissions standards for moving sources); Solid Waste Disposal Act $\S 3008(\mathrm{~d}), 42$ U.S.C. $\S$ 6928(d) (2003); Toxic Substances Control Act § 16(b), 15 U.S.C. § 2615(b) (2003); Federal Insecticide, Fungicide and Rodenticide Act $\S 14(\mathrm{a})$ \& (b), 7 U.S.C. $\$ 136$ (a) \& (b) (2003); Emergency Planning and Community Right-to-Know Act of $1986 \S 325(b)(4), 42$ U.S.C. $\S$ 11045(b)(4) (2003). Civil penalties are provided for in Endangered Species Act $\S 11(\mathrm{a}), 16$ U.S.C. \& 1540(a); Clean Water Act $\S 309$ (b), 33 U.S.C. $\$ 1319(\mathrm{~b})$, and $\S 309(\mathrm{~g})$, 33 U.S.C. $\S$ $1319(\mathrm{~g})$; Clean Air Act $\$ 205(\mathrm{~b}), 42$ U.S.C. \& 7524(b); Solid Waste Disposal Act \& 3008(g), 42 U.S.C. $\$ 6928(\mathrm{~g})$; Toxic Substances Control Act $\$ 16(\mathrm{a}), 15$ U.S.C. $\$ 2615(\mathrm{a})$; Federal Insecticide, Fungicide and Rodenticide Act $\$ 14(a), 7$ U.S.C. $\$ 136 /(a)$; Emergency Planning and Community Right-to-Know Act § 325(a), 42 U.S.C. § 11045(a); Surface Mining Control and Reclamation Act $\S 518,30$ U.S.C. $1268(2003)$.

55. The Superfund law, or "CERCLA," provides for strict, joint, and several liability for the "release" of hazardous substances into the environment. 42 U.S.C. $\$ \$ 9601-9675$ (2003). Also, the Oil Pollution Act of 1990,33 U.S.C. $\$ \S 2701-2761$ (2003), passed in the wake of the disastrous Exxon Valdez spill, is written in a manner similar to CERCLA, providing for liability for the costs of removal and damages to natural resources. See 33 U.S.C. $\$ 2702$.

56. Also known as the Federal Water Pollution Control Act.

57. 33 U.S.C. $\$ 1319(\mathrm{c})(1)$.

58. Id. $\$ 1319(\mathrm{c})(2)$.

59. Id. $\$ 1319(\mathrm{c})(1) \&(2)$.

60. Id. $\S 1319(\mathrm{c})(3)(\mathrm{A})$.

61. See, e.g., Solid Waste Disposal Act $\S 3008$ (d) \& (e), 42 U.S.C. $\S 6928($ d) \& (e) (2003); Emergency Planning and Community Right-to-Know Act $\S 325(b)(2),(3), \&(4), 42$ U.S.C. $\S$ 11045(b)(2), (3), \& (4) (2003). But see Federal Insecticide, Fungicide and Rodenticide Act § 
wide range of penalties could accommodate the differing degrees of harm imposed, but it is curious that the structure of the criminal penalty provisions do not reflect a graduated scale of penalties keyed to the extent of harm.

Thus, environmental initiatives that adopt labels such as "polluter pays"62 reflect a principle that polluters might see as retributive in nature, ${ }^{63}$ rather than compensatory ${ }^{64}$ I refer to this version of fairness as a "retributive" sense of fairness. ${ }^{65}$ This version of fairness has a strong appeal to a legal profession and a society that seem to have a stronger grasp of notions of criminal law and notions of culpability, than it does of notions of efficiency.

By themselves, these notions of fairness seem appropriate. But an examination of the way in which fairness has distorted environmental laws and policies reveals the problems with relying excessively upon these types of fairness considerations. Again, I argue not for an abandonment of fairness considerations, but for an honest look at the pathologies that a fairness orientation has wrought.

\section{WHAT IS WRONG WITH FAIRNESS?}

The fundamental problem with relying upon fairness to guide environmental law and policy is that there is no widely agreed-upon and principled basis on which to choose from among competing assertions or competing versions of fairness. Fairness is thus not one coherent concept, but many different concepts. While still important and useful, it cannot serve as the sole decision criteria in environmental law and policy.

14(a)(4), 7 U.S.C. $\$ 136 /(a)(4)$ ("Whenever the Administrator finds that the violation occurred despite the exercise of due care or did not cause significant harm to health or the environment, the Administrator may issue a warning in lieu of assessing a penalty.") (emphasis added).

62. The Clinton administration used the "polluter pays" principle as a rhetorical tool to push for reform of the Comprehensive Environmental Response, Cleanup and Liability Act (the "Superfund" law). Superfund: Browner to Try Administrative Fixes Before Seeking Legislative Action, 24 ENVTL. REP. 39, May 14, 1993; Richard M. Gold \& Kris. L. North, "Moderation" is Watchword for Upcoming Congress, 7 FLA. ENVTL. COMPLIANCE UPDATE, Jan. 1997, at 1.

63. Jonathan Remy Nash, Too Much Market? Conflict Between Tradable Pollution Allowances and the "Polluter Pays" Principle, 24 HARv. ENVTL. L. REv. 465, 466 (2000) ("The polluter pays principle is a normative doctrine of environmental law. Although its precise legal definition remains elusive, the core of this principle stems from the fundamental, logical, and fair proposition that those who generate pollution, not the government, should bear pollution costs."). Nash notes that the "weak" form of the principle is economic in nature, merely requiring that externalities be internalized, $i d$. at $473-74$, while the "strong" form of the principle requires that the additional costs of pollution abatement be borne by the polluter. id. at 476-77. See also William J. Baumol \& Wallace E. OAtes, The Theory of Environmental Policy 180-81 (2d ed. 1988).

64. A "polluter pays" principle could also be designed in such a way as to reflect the efficiency-oriented notion that monetary penalties should be levied to internalize externalities. See infra notes $156-157$.

65. As noted in note 50 , this phrase is attributable to Kaplow and Shavell. 
It is perhaps a naïve view of lawmaking that this problem is of such importance, and that persuasion and rhetoric are used at all to resolve conflicts between competing stakeholders. This would certainly be the objection posed by public choice theory, which posits that political arenas emulate markets, with political favor being purchased by rent-seekers and sold by political actors, making debate somewhat irrelevant. ${ }^{66}$ However, not even strong adherents of public choice theory would say that public choice theory explains all legislative and administrative decisions, ${ }^{67}$ or that it is completely pointless to pay attention to persuasion and rhetoric. There is clearly some role, and often a very important role, to be played by the task of persuading others on the merits of policy positions. The prominence of a "civic republicanism" literature is a counterpoint to public choice theory, suggesting that democratic decision-making is just as dependent upon political deliberation and the notion of shared interests, as it is on economic power and the notion of individual interests. ${ }^{68}$ Thus, in the positive debate between public choice theory on the one hand, and the civic republicans on the other hand, I plant myself firmly in the middle. I certainly disagree with the extreme position that market forces in political arenas are so strong that there is no point to studying our modes of debate, but I also acknowledge that public choice theory explains many legislative and administrative decisions and presents a parsimonious and powerful

66. Daniel Farber \& Philip Frickey, The Jurisprudence of Public Choice, 65 TEX. L. REV. 873, 878 (1987); Jonathan Macey, Promoting Public-Regarding Legislation Through Statutory Interpretation: An Interest Group Model, 86 ColuM. L. REv. 223, 223-24 (1986).

67. See, e.g., Jonathan R. Macey, Cynicism and Trust in Politics and Constitutional Theory, 87 CORNELl L. REV. 280, 283 (2002)

(Some governments use their power to correct market failures, supply public goods, and enforce contracts. Other governments use their power to help businesses. Still other governments use their power to enrich themselves and their friends at the expense of the public interest.... I argue that particular governments can, and often do, use their power in all three ways simultaneously.)

Michael E. DeBow \& Dwight R. Lee, Understanding (and Misunderstanding) Public Choice: $A$ Response to Farber and Frickey, 66 TEX. L. REV. 993, 996 (1988)

(The analytical power of public choice theory ... lies in the analyst's willingness to proceed from a simplifying set of assumptions. But public choice theory does not depend on the assumption that individuals make decisions solely to promote their narrowly defined economic interests. People obviously place positive value on a wide range of things, and acknowledging this fact in no way handicaps public choice theory.)

Saul Levmore, From Cynicism to Positive Theory in Public Choice, 87 CORNELl L. REv. 375, 376 (2002) ("Public choice might explain or inform a good many things, even as there are matters better explained or even only explained with some other tool ....").

68. Civic republicanism is characterized by four "central commitments." They are: (1) deliberation in politics, (2) political equality, (3) "universalism," or a notion of shared or common interests, and (4) participation in political life. Cass R. Sunstein, Beyond the Republican Revival, 97 Yale L.J. 1539, 1548-58 (1988). See also Mark Seidenfeld, A Civic Republican Justification for the Bureaucratic State, 105 HARV. L. REV. 1511, 1528-29 (1992). 
explanation of environmental law and policymaking. Indeed, the need to curb rent-seeking is one motivation for my suggestion to seek out more efficiency-thinking and less fairness-thinking.

Public choice theory and pluralism also hint at a normative agenda. While some view public choice theory as primarily positive in nature, ${ }^{69}$ some variants of public choice theory, such as the notion of regulatory capture ${ }^{70}$ strongly suggest a need to shrink government bureaucracies. ${ }^{71}$ To the extent that there is a normative debate between the public choice camp and civic republicans, I place myself firmly in the civic republican camp. My thesis is that a public interest exists, and that we should choose a mode of persuasion and a form of rhetoric that most effectively illuminates and serves that public interest. In other words, my thesis that we should persuade in the language of efficiency instead of fairness necessarily assumes that we should have public debate that influences government, and not simply a government that furthers purely private interests.

Taking as given the pertinence of political debate and persuasion and the desirability of pursuing the public interest, we must continue refining our dialogue and modes of persuasion. In that vein, I argue that debate over environmental laws and policy can be conducted more effectively with less fairness rhetoric and more efficiency rhetoric. I aim to show that fulfillment of the public interest, the objective of a civic republican government, is better accomplished by a debate that pays more attention to efficiency than has been the case. This section discusses four reasons why more efficiency-thinking and less fairness-thinking would help.

First, to the extent that public choice theory is useful as a positive theory-in modeling political decisions as simple market transactions-

69. Farber \& Frickey, supra note 66, at 878-79; Levmore, supra note 67, at 375; David B. Spence \& Frank Cross, A Public Choice Case for the Administrative State, 89 GEO. L. J. 97, 100 (2000) ("[A]t its core, public choice scholarship is more of a 'how' than a 'what,' more of an analytical method than a particular set of conclusions.").

70. The notion of regulatory capture is that regulatory agencies respond to the regulated entities rather than act in the public interest. Theories abound as to the exact mechanism of how this might take place. One is that repeated regulatory encounters between regulators and regulated entities, where both have some means of punishing or rewarding the other, will give rise to implicit cooperation. See IAN AYRES \& JOHN BRAITHWAITE, RESPONSIVE REGULATION: TRANSCENDING THE DEREgULATION DEBATE, 54-56 (1992). Another theory of capture stems from George J. Stigler's The Theory of Economic Regulation, 2 BELL J. ECON. \& MGMT. 3, 3 (1971), which demonstrated how industries may lobby for and acquire regulation when it serves to insulate them from competition. Finally, a "revolving door" system of regulation in which regulators are employed by the regulated entities after the regulator leaves the government is one in which the potential for capture is obvious. Jeffrey J. Rachlinski \& Cynthia R. Farina, Cognitive Psychology and Optimal Government Design, 87 CORNELL L. REV. 549, 568 (2002).

71. See, e.g., WILlaM A. NISKANEN, BUREAUCRACY AND REPRESENTATIVE Government (1971); Stigler, supra note 70. But see Spence \& Cross, supra note 69; David B. Spence, A Public Choice Progressivism, Continued, 87 CORNELl L. REV. 397 (2002). 
fairness cloaks the subversion of the public interest by focusing on the benefits to the rent-seeker, rather than the harm to the public. Second, fairness-thinking makes identifying opportunities to reduce pollution in the future more difficult, because by insisting on honoring every stakeholder's rights, fairness-thinkingcreates a multitude of potential vetoes. Third, fairness skews environmental law in favor of regulated industries because the costs of pollution reduction fall on identifiable parties, while the benefits inure to unidentifiable persons-future and otherwise anonymous victims of pollution. Outcomes are skewed because fairness always seems more compelling when associated with identifiable persons. Finally, fairness exacerbates the bias created by scientific uncertainty surrounding environmental problems. Because of human tendencies towards optimism, when uncertainty comes up against fairness, fairness wins, with a resulting bias against pollution reduction.

\section{A. A Public Choice Perspective}

Even where legislative and administrative decisions appear to be the result of a political transaction explainable by public choice theory, fairness is often invoked to justify the decision. Fellow legislators and the general public apparently need to be reassured that there is a moral justification for a proposal that coincidentally benefits a generous constituent of the sponsor. The invocation of fairness is itself evidence that persuasion and debate are not obsolete. To the extent that persuasion and moral justification are still an integral part of our public policy-making process, then, do we want debates to be couched in fairness terms or efficiency terms? Both, but I argue that a greater emphasis on efficiency will better reveal the degree to which the public interest is being thwarted by private interests.

For example, massive farm subsidies have been continuously justified by fairness arguments. Legislators with farming constituents have repeatedly invoked a distributive sense of fairness to justify subsidies, citing a need to help American farmers survive competition from foreign agricultural interests that they deem to be unfairly subsidized..$^{2}$ An expectations sense of fairness has also been invoked on

72. For example, section 338 of the Concurrent Resolution 290, Concurrent Resolution on the Budget, Fiscal Year 2001, reads as follows:

SEC. 338 SENSE OF THE SENATE REGARDING FAIR MARKETS FOR AMERICAN FARMERS. It is the sense of the Senate that the levels in this resolution assume that-(1) the United States should take steps to increase support for American farmers in order to level the playing field for United States agricultural producers and increase the leverage of the United States in World Trade Organization negotiations on agriculture as long as such support is not trade distorting, and does not otherwise exceed or impair existing Uruguay Round obligations; and 2) such actions 
behalf of farmers, on the theory that their investments were based upon an expectation that subsidies would continue. ${ }^{73}$ In terms of efficiency, farm subsidies are a travesty. Subsidization produces benefits to farmers, but the benefits are far less than the cost of the subsidy and the cost of administering it. For example, a 1995 General Accounting Office report estimated that the cost of the federal subsidy program for cotton averaged $\$ 1.5$ billion annually from 1986 to 1993 , and yielded only $\$ 754$ million annually in benefits to cotton farmers. ${ }^{74}$ Agricultural subsidies are also, incidentally, grossly unfair to most American taxpayers. Ironically, since the subsidies inure mostly to the benefit of large corporate farmers, they are manifestly unfair to smaller farmers struggling to stay in business $^{75}$ and low-income consumers hurt by price support mechanisms. ${ }^{76}$

should improve United States farm income and restore the prosperity of rural communities.

H.R. Con. Res. 290, 106th Cong. (2000).

Also:

[T] he US has already more than achieved these reductions [required by international trade agreements], by reducing spending by over 70 percent from the 1986 base year. On the other hand, in this same time-frame the European Union (EU) has increased spending by over 200 percent. To require the US is to make further reductions in such programs without requiring similar corresponding reduction by the EU and other foreign competitors would be unfair to US farmers. US agriculture currently faces a farm program disadvantage. Further cuts in US agriculture spending-as proposed in this budget resolution-will worsen the situation. Not only will our farmers be disadvantaged, but American consumers will share in their loss.

H.R. REP. 104-120, reprinted in 1995 WL 302263 at $* 191$ (statement of Rep. Earl Pomeroy) (emphasis added).

73. For example:

I thank the Chair. Madam President, I thank the Senator from Arkansas for her excellent statement in opposition to this amendment. I rise in strong opposition.... [Farmers have] provided this country a cheap, affordable, reliable, safe, and environmentally protected food supply. And what the proponents of this amendment are seeking to do is to absolutely pull the rug out from under the producers who have provided this great condition in this country. In Arkansas, agriculture is 25 percent of the State's economy, but that does not even tell the story because it does not account for the thousands of jobs that are related to agricultural production, such as bankers, car dealers, implement dealers, schools, restaurants, and may I say even churches that are dependent upon the survival of the farm economy.

148 CONG. REC. S441-07, S449-S450 (2002) (statement of Sen. Hutchinson).

74. U.S. GEN. ACCOUNTING OFFICE, COTTON PROGRAM: COSTLY AND COMPLEX GOVERNMENT PROGRAM NEEDS TO BE REASSESSED 1, 47 (1995).

75. A study sponsored by the Environmental Working Group showed that federal farm payments from 1996 through 1998 under the 1996 Freedom to Farm Act provided minimal financial assistance for the large majority of farmers, mostly small and medium-sized operations, while large farming operations received the lion's share. From 1996 through 1998 nearly sixtyone percent of all Freedom to Farm subsidies were paid to 144,000 individuals, corporations and farm partnerships among the top ten percent of subsidy recipients in terms of income. These recipients were paid an average of $\$ 95,875$ per year, not including income from agricultural commodity sales or from payments under other farm programs, such as federal conservation, disaster or crop insurance programs. Meanwhile, the 700,000 farmers constituting the lower half of subsidy recipients (in terms of income) were paid an average of about $\$ 1,200$ per year, ClARK 
Worst of all, farm subsidies that depress market prices undermine the ability of developing countries to compete in the world marketplace, depriving them of the opportunity to export goods and crawl out of poverty. ${ }^{77}$ These fairness arguments have failed to persuade legislators to even reduce, let alone abandon, agricultural subsidies.

Public choice theorists also have some easy pickings in environmental law. The American electricity-generating industry has consistently and successfully defended its capital investments in coal-fired power plants from new pollution regulations, on the grounds that tighter regulation would render plants less profitable and perhaps obsolete, leaving the industry with unexpected "stranded costs." The obsolescence of these dinosaurs of the modern industrial age stems not only from their relative inefficiency, ${ }^{79}$ but also from the increasing evidence of the harmfulness of plant emissions to human health ${ }^{80}$ and

WILLIAMS-DERRY \& KEN COOK, ENVTL. WORKING GROUP, GREEN ACRE\$: HOW TAXPA YERS ARE SUBSIDIZING THE DEMISE OF THE FAMILY FARM 3 (2000).

76. INT'L MONETARY FUND \& THE WORLD BANK, MARKET ACCESS FOR DEVELOPING COUNTRY EXPORTS - SELECTED ISSUES 24 (2002).

77. Subsidized farming in developed nations suppresses the price of subsidized agricultural commodities, making it more difficult for farmers in developing countries to compete, since their cash-strapped governments cannot afford to match the subsidies paid by the governments of developed nations. See id. at 33; Elizabeth Becker, Western Farmers Fear Third-World Challenge to Subsidies, N.Y. TIMES, Sept. 9, 2003, at A1; Amadou Toumani Toure \& Blaise Compaore, Your Farm Subsidies Are Strangling Us, N.Y. TIMES, July 11, 2003, at A17. Developing nations hurt by agricultural subsidies withdrew in protest from the most recent round of World Trade Organization negotiations over trade policy. Elizabeth Becker, Poorer Countries Pull Out of Talks Over World Trade, N.Y. TimES, Sept. 15, 2003, at A1.

78. See John Burritt McArthur, Cost Responsibility or Regulatory Indulgence for Electricity's Stranded Costs? 47 AMER. U. L. REV. 775, 776-77 (1998). The term "stranded costs" has been used more frequently in conjunction with concerns about the effects on electricity deregulation on capital investments, but the effect of environmental controls would similarly make some plants unprofitable. See text accompanying notes 184-185.

79. It should come as no surprise that the electricity generating industry has been one of the most stagnant in the dynamic U.S. economy-research and development expenditures in recent years have generally been about $0.2 \%$ of profits, as compared with $3.6 \%$ in other manufacturing industries. NORTHEAST-MIDWEST INST., THE CLEAN AIR-INNOVATIVE TECHNOLOGY LINK: ENHANCING EFFICIENCY IN THE ELECTRICITY INDUSTRY 13 (1999). From about 1920 to the present, the efficiency of the electricity generation process, on average, has increased from about twenty percent to thirty-three percent. $J d$. at 29 fig.5. Compare that with the semiconductor industry, which has doubled computing speeds every eighteen months for the last two decades. John Markoff, Time to Repeal Moore's Law? INT'L HeRALD TRIB., Apr. 11, 2003 , at 1 .

80. An epidemiological study released last year by the Rockefeller Foundation found that particulate matter pollution from coal-fired power plants owned by just eight firms caused the premature deaths of about 5,900 persons per year. ABT ASSOCIATES, PARTICULATE-RELATED HEALTH IMPACTS OF EIGHT ELECTRIC UTILITY SYSTEMS 4-2 (2002), available at http://www.rffund.org/abt\%20report

\%20FINAL.pdf. The study was the latest in a growing literature on the statistical link between coal-fired power plant pollution and a variety of health effects, such as premature death due to lung cancer and cardio-pulmonary disease, asthma, chronic bronchitis, and other respiratory ailments. See id. at 3-6 to 3-14; $c f$. BYRON SWIFT, ClEANER POWER: THE BENEFITS AND COSTS 
ecological systems. ${ }^{81}$ Yet the industry has eschewed retooling in favor of seeking federal subsidies to reduce the pollution generated by coal combustion. Various forms of "clean coal technology" have been proposed, and from time to time, funded by taxpayers, ${ }^{82}$ and legislation is currently pending on a proposal to provide an additional $\$ 2.2$ billion. ${ }^{33}$

Logging companies that depend upon federal lands for their timber have also been effective rent-seekers. A network of taxpayer-funded logging roads to help these logging companies harvest trees on federal lands that is eight times as long as the interstate highway system ${ }^{84}$ has sustained logging companies that are too inefficient to operate in a competitive environment, and promoted logging practices that wreak environmental havoc. ${ }^{85}$ And Western hard rock mining interests may be

of Moving from Coal to Natural Gas Power Generation 14 (2000), available at http:/www.eli.org/; David R. Wooley, Environmental Comparability, 12 NAT. RES. \& ENV'T 276, 276 (1998); Peter Huber, Electricity and the Environment: In Search of Regulatory Authority, 10 HARV. L. REv. 1002, 1046 (1987); Coal, Environmental Enemy No. 1, ECONOMIST, July 6th, 2002, at 11 (noting the various environmental problems caused by coal combustion for energy production, including carbon dioxide emissions).

81. Sulfur dioxide emissions from coal-fired power plants mix with moisture to produce sulfuric acid that falls as acid rain, making lakes and rivers more acidic. This makes lakes and rivers inhospitable to many native organisms and interferes with many ecological functions of aquatic ecosystems. See EPA, EFFECTS OF ACID RAIN: LAKES \& STREAMS, at http://www.epa.gov/airmarkets/acidrain/

effects/surfacewater.html\#ecosystems (last updated Nov. 12, 2003). Acid rain has also had documented effects on terrestrial life, injuring or slowing the growth of forests unaccustomed to highly acidic soil. See EPA, EFFECTS OF ACID RAIN: Foresis, http://www.epa.gov/airmarkets/acidrain/effects/forests.html (last updated Nov. 12, 2003).

82. For example, $\$ 575$ million was appropriated for clean coal technology demonstration projects. Pub. L. No. $100-446,102$ Stat. 1774,1810 (1988). This was later increased to $\$ 1.2$ billion. Pub. L. No. 101-121, 103 Stat. 701, 728 (1989).

83. Legislation Introduced in Both Houses to Promote Research Into 'Clean Coal', ENV'T ReP., Mar. 21, 2003, at 637.

84. There are 377,810 miles of roads in the National Forest System. U.S. FOREST SERV., REPORT OF THE FOREST SERVICE, FISCAL YEAR 1995, at 129. Washington, DC: June 1996. There are 46,748 miles of interstate highways in the United States. FED. HIGHWAY ADMIN., U.S. DEP'T OF TRANSP., PUBLIC ROAD LENGTH (2002), at http://www.fhwa.dot.gov/policy/ohim/hs02/hm16.htm.

85. Past road-building and logging practices, in particular, have been blamed for severe disruptions to forest ecosystems. See, e.g., U.S. GEN. ACCOUNTING OFFICE, OREGoN WATERSHEDS: MANY ACTIVITIES CONTRIBUTE TO INCREASED TURBIDITY DURING LARGE STORMS 4-7 (1998); U.S. GEN. ACCOUNTING OFFICE, FOREST SERVICE ROADLESS AREAS: POTENTIAL IMPACTS OF PROPOSED REgulations ON ECOlogical Sustainability 13-15 (2000). Former Senator Richard Bryan noted in a floor speech in support of a bill to reduce logging subsidies that according to the GAO, the below-cost timber sales program cost taxpayers at least $\$ 1.5$ billion from 1992 to 1997 , while providing only four percent of the nation's timber supply. The poor construction of logging roads has led to numerous environmental problems such as soil erosion, fragmentation of intact forest ecosystems, the spread of noxious weeds and invasive species, reduction of forest habitat for wildlife, stream siltation, lower water quality and degraded fish habitat. The timber industry's responsibility for maintaining logging roads ends with the end of the timber sale, leaving all future maintenance costs to the taxpayer. 145 CONG. REC. S10,754-03 (1999) (statement of Sen. Richard Bryan). 
the most effective rent-seekers of all, resisting significant amendment to the Mining Law of 1872 that permits them to patent mining claims on federal public land for the pitiful amount of $\$ 2.50$ to $\$ 5$ per acre, ${ }^{86}$ and to avoid paying any royalties on extracted materials to the U.S. Treasury ${ }^{87}$ Meanwhile, U.S. taxpayers face a cleanup bill of $\$ 32$ to $\$ 72$ billion for reclamation of abandoned mines. ${ }^{88}$

Why have we continued to subsidize and perpetuate such environmentally harmful industries? Clearly, the rent-seeking explanation favored by public choice theorists is powerful, but it does not explain why such appropriations gain the support of those whose constituents might be harmed by the subsidies. These programs consistently pass, even though they are detrimental to a majority of Americans whose congressional representatives constitute a majority of votes in both chambers. The answer to this puzzle might be political logrolling ${ }^{89}$ in which other members of Congress get their own sweets in these appropriations bills or are rewarded in other ways. But even this explanation is not completely satisfying. How do we justify such pork barrel subsidies at all? Lawmakers do not introduce legislation and simply declare, "this will benefit my constituents and help me get reelected." The answer lies in how we view such subsidies. These subsidy programs are almost always expressed as government programs to help downtrodden people, to insulate them from the unfair vicissitudes of markets and weather, unfair trade practices of other countries, or other sources of misfortune. We justify these subsidy programs by playing on sympathy, and invoking fairness.

An examination of the congressional floor statements made by proponents reveals that some invocation of fairness is almost always used to justify these measures. An expectations version of fairness has been invoked to maintain an exemption for old, coal-fired power plants from new pollution control standards..$^{90}$ In addition to serving the investment

86. 30 U.S.C. $\$ 37(1872)$.

87. Id.

88. EARTHWORKS. H.R. 2141, THE Mineral EXPloration AND DEVELOPMENT ACT OF 2003, at http://www.mineralpolicy.org/publications/ pdf/LastAmericanDinosaur.pdf (last visited Mar. 10, 2004).

89. Logrolling is the practice of legislative vote trading for projects favored by individual lawmakers. See, e.g., John F. Manning, The Absurdity Doctrine, 116 HARV. L. REV. 2,387, 2,417 (2003).

90. Power plants built before 1972 enjoy "grandfathered" status, exempting them from stringent emissions standards that apply to sources built since 1972. This exemption disappears once the company attempts to upgrade the plant. Recently, the House Committee on Government Reform scolded the EPA for bringing suit against some coal-fired power plants for making plant modifications that might have triggered New Source Review, robbing them of their grandfathered benefit. The Subcommittee on National Economic Growth, Natural Resources, and Regulatory Affairs stated that "[its] major concerns are that EPA's retroactive change in its rules is unfair and may force utilities to delay or forgo important maintenance projects, risking 
expectations of utilities, fairness concerns for employees-power plant workers and coal miners-have also animated discussion of clean coal technology subsidies. ${ }^{91}$ An expectations sense of fairness that pays homage to the reliance of logging companies on the continuance of such subsidies has figured prominently in the rhetoric justifying continuation of the subsidies, ${ }^{92}$ as has concern for the welfare of workers. ${ }^{93} \mathrm{~A}$ distributive sense of fairness has been used to justify subsidizing a timber industry that faces competition from Canadian imports. ${ }^{94}$ And the hard

worker safety and electricity reliability at these units, to the detriment of the public." H.R. REP. No. 106-1053, at 356-57 (2001).

Examples of congressional concern for the investments of electric utilities are acute: "We must honor past regulatory schemes and commitments and allow recovery of stranded investments. Electric utilities incurred 'stranded costs' under a regulatory scheme not of their choosing. These utilities made long-term decisions based upon decades of regulation. To deny industry the recovery of these costs would go against the fairness that I spoke of earlier." 145 CONG. REC. H2309-02, 2310 (1999) (statement of Rep. Stearns).

91. For example: "K-fuel is an important program. It's important to Beloit. It's important to my constituents. And it's most important to thousands of workers across the Midwest who work at coal-burning factories. This grant needs to be funded." 137 CONG. REC. E3745-03 (1991) (statement of Rep. Aspin). And:

With continuing concern expressed over both acid rain and the need to further control emissions from coal burning powerplants; with more than a half of our electricity generation derived from the combustion of coal-and that percentage is projected to increase; with a staggering foreign trade deficit contributed to in substantial measure by the billions of dollars in oil and petroleum product imports paid each year; and with unemployment still plaguing the coal producing regions of this country, I believe there is every reason to support the development of clean coal technologies that will allow the use of coal in an environmentally acceptable manner.

133 Cong. Rec. S5950-01 (1987) (statement of Sen. Ford). Ironically, a sense of fairness to Eastern coal workers, who mine higher-sulfur coal, helped the EPA justify imposing a "scrubber" technology requirement on new power plants, a technology that would remove sulfur dioxide pollution from power plant emissions so thoroughly (see infra text accompanying note 403) that power plants could continue to use high-sulfur eastern coal, instead of low-sulfur western coal. This odd coalition of environmentalists and coal miners helped preserve Eastern coal mining jobs. See BrUCE A. ACKERMAN \& WILliam T. HASSLER, ClEAN COAL/DirTY Air $31(1981)$.

92. Senator Gorton, arguing for legislation reversing administrative decisions to curtail subsidized logging and road construction on federal lands, said

$[\mathrm{M}$ |any people lose their jobs every day and life goes on. The truth is that timber communities exist because the Federal Government made a promise decades ago that if these workers would move there they could harvest a sustainable amount of Federal timber forever. These are towns with practically no other economic options. Timber workers laid off in a timber town whose houses have lost virtually all of their values, are not like most laid-off workers. They have no other realistic options, and the Federal promise of job retraining is a national scandal that does not work.

140 Cong. Rec. S11326-05 (1994) (statement of Sen. Gorton).

93. Representative Taylor said, "What have we done to 191 million acres of U.S. forestlands that were heretofore reserved for timber, one of the prime, part of the multiple-use purpose? We have reduced that to about 25 percent ... This amendment will cost us another 45,000 jobs." 141 CONG. REC. H7102-02, 7129 (1996) (statement of Rep. Taylor).

94.For example: 
rock mining industry has used fairness arguments to successfully resist the imposition of any royalties for mining on federal lands. ${ }^{95}$ Meanwhile, fairness arguments made on behalf of environmental values or taxpayers have been famously unsuccessful. For example, fairness arguments to impose royalties and to force the hard rock mining industry to pay for the $\$ 32$-to- $\$ 72$ billion cleanup on federal lands have proven futile. ${ }^{96}$

\begin{abstract}
U.S. producers are suffering as lumber prices remain terribly depressed. From 1977 to 1984,629 U.S. lumber mills were forced to close their doors. In the same period of time the number of Canadian softwood lumber mills actually increased by a number of 85 . From 1977 to 1984 over 30,000 U.S. workers employed directly by softwood lumber mills lost their jobs as U.S. mill employment dropped over 25 percent from 119,553 to 89,133 .
\end{abstract}

132 Cong. Rec. H843-01 (1986) (statement of Rep. Craig).

95. Senator Burns said:

The point I am making, if we change the rules now, let us go back and change all the land that has been granted by this Government and put into private hands. And let us say: OK; now we want to start charging a royalty on what you produce on your farm. Is that fair? That is kind of changing the rules, is it not, here in the middle of the game? Is that not a violation of private property rights?

138 CONG. REC. S11,556-02, 11,568 (1992) (statement of Sen. Burns).

96. On a proposal by Sen. Bumpers to levy royalties under legislation proposed in 1997:

The hardrock mining companies contend that they would be forced to shut down operations if they were required to pay royalties to the Federal Government. However, these same companies find themselves able to pay royalties for mining operations on State and private lands. In fact, the Newmont Mining Co. pays an 18 percent royalty on land acquired from private interests on a portion of its gold quarry mine in Nevada's Carlin Trend. Ironically, a hardrock miner operating on acquired Federal lands pays a royalty to the Federal Government while his counterpart on lands subject to the mining law pays nothing. There is no justifiable reason for this difference.

Billions of dollars' worth of hardrock minerals are extracted from the public lands. It is absolutely unfair to the taxpayers of this country to permit hardrock companies to enjoy the same tax breaks as others, while failing to adequately compensate the public landowners. The legislation I am introducing today seeks to remedy this result.

143 Cong. Rec. S1383-01, 1394 (1997) (statement of Sen. Bumpers). On a proposal to levy royalties under legislation proposed in 1993:

Madam Chairman, once again this body must make a choice. Will we choose special deals for the few or a better deal for all Americans? Just like grazing, the question here today is not whether a way of life is endangered but whether the U.S. taxpayers will get fair market value for the resources which belong to all of us. And just like grazing, some of the biggest beneficiaries of the hardrock mining program are large corporations, many of which are foreign-owned. Yet, each year they take billions of dollars' worth of gold, silver, uranium, copper, lead, cobalt, platinum, and palladium from the public lands and don't pay one red cent of royalties to the taxpayers.

139 Cong. Rec. H9739-02, H9765 (1993) (statement of Rep. Synar). On a proposal to levy royalties under legislation proposed in 1992:

Under existing law, the hardrock industry is the only major extractive industry on federal lands that does not pay a royalty to the fedcral government for the privilege of mining on our public lands. The oil and gas industry and the coal industry all pay a royalty of $12.5 \%$ of the value of minerals extracted on federal lands. The National 
Would subversions of the public interest be possible without fairness arguments? Almost certainly, but a little efficiency analysis would make much clearer the fact that the subsidies are a naked wealth transfer from taxpayers to a small group, with little public interest justification. ${ }^{97}$ It might then be more politically costly for a congressional member to support a subsidy that does not benefit her constituents. Fairness rhetoric and fairness-thinking, I submit, have played an important role in promoting and permitting these subversions of the public interest. If efficiency rhetoric and efficiency-thinking were invoked with greater emphasis and frequency, the public interest would receive greater recognition and consideration. Possibly, just possibly, efficiency thinking would render rent-seeking subsidies just slightly more difficult to obtain.

\section{B. Egocentrism and the Narrowing Windows of Opportunity}

Even without painting a cynical political picture, however, it is easy to see how the vagaries of these notions of fairness might be problematic. Buzz Thompson has written about the widely-studied propensity of humans to indulge in "egocentric interpretations of fairness." That is, given multiple conceptions of what is fair, it is human nature to choose the most self-serving one. ${ }^{99}$ This prevalent pathology has proven to be an insurmountable barrier to the solution of many environmental problems that could be solved by cooperation. ${ }^{100}$ In the cases discussed by

Taxpayers Union believes that a fair return to the federal government for the private profit gained from the public's mineral resources is warranted. At a minimum, we support H.R. 918's 8\% royalty for hardrock minerals. However, we also support Rep. DeFazio"s (D-OR) expected floor amendment that will raise the royalty rate H.R. 918 to the standardized and justifiable level of $12.5 \%$.

138 Cong. Rec. H11,047-02, 11,050 (1992) (statement of Jill Lancelot, Director of Congressional Affairs, Washington Taxpayers Union).

On a proposal to force mining interests to contribute to the cost of cleanup: [O]ver the course of these past 130 years... the mining industry has caused tremendous environmental damage throughout the West. Mining waste dumps are responsible for poisoning streams, lakes, and ground water with toxic minerals such as lead, cadmium, and arsenic. Mining in the United States has left a legacy of 12,000 miles of polluted streams and 180,000 acres of polluted lakes. There are 500,000-plus abandoned mines in this country. Guess who pays for the cleanup. The taxpayers. That bill is estimated to be between $\$ 32$ and $\$ 72$ billion.

145 CONG. REC. S9348, 9351,(1999) (statement of Sen. Murray).

97. Farm subsidies have been justified on a food security basis, but food security can be accomplished by subsidies considerably smaller than the present ones.

98. Barton Thompson, Tragically Difficult: Obstacles to Governing the Commons, 30 ENVTL. L. 241, 260 (2000).

99. See id.

100. Thompson, in his article, discusses some common pool resource problems, and how solutions to resource overuse problems have been elusive, in part because of the egocentric interpretations of fairness. Examples include groundwater overdrafting, global warming, and overfishing. See id. at 246-55. 
Thompson, competing egocentric interpretations of fairness produced stalemates that thwarted cooperative solutions. A political stalemate of a similar sort has developed at the national level. National environmental policy has been held captive by multiple competing conceptions of fairness, and this condition has rendered it much more difficult to identify acceptable pollution reduction strategies.

The egocentrism problem manifests itself now because many of the least expensive and most beneficial pollution reduction measures have already been undertaken in the first twenty years of environmental law. ${ }^{101}$ In economic terms, the marginal costs of abatement tend to increase with greater abatement, because in general the least expensive reductions are undertaken first. ${ }^{122}$ At the same time, marginal benefits tend to decrease with greater abatement, because as a general matter the pollution reductions first undertaken tend to be the most important and the most beneficial. Thus, the first steps of pollution abatement exploited an enormous gap between the marginal cost and marginal benefit of abatement and made it possible to enact environmental legislation that accommodated both the environmental side and the regulated side in terms of their egocentric views of fairness. With fewer remaining opportunities to reduce pollution at relatively low cost, egocentrism will make it difficult for environmental solutions to accommodate competing notions of fairness.

Of course, not all of our opportunities to reduce pollution at relatively low cost have been exhausted. But coalitions of interest groups can cumulate their egocentrism, and defeat even cost-effective proposals to reduce pollution. In 1994, as part of a plan to reduce what was then considered a dangerously high deficit, President Clinton proposed a "BTU tax" to be levied on consumer energy bills. ${ }^{103}$ While supported by environmentalists ${ }^{104}$ and by some economists, ${ }^{105}$ the BTU tax fell victim to

101. Supra note 18; see also Richard A. Epstein, Too Pragmatic By Half, 109 YALE L. J. 1639, 1657-58 (2000); Francis S. Blake, The Economic Impact of Environmental Regulation, 5 NAT. RES. \& ENV'T. 23, 56 (1990); Walter G. Wright, Jr. \& Mary Ellen Henry, The Arkansas Air Pollution Program, Past, Present and Future, 51 ARK. L. REV. 227, 241 (1998).

102. See Water Pollution Control Legislation: Hearing on H.R. 11896 and H.R. 11895 Before the House Comm. on Public Works, 92d Cong. 213 (1971) (testimony of CEQ, CEA, and EPA) [hereinafter "CWA Legislative History"]. Or, as Krier might argue, the most politically inexpensive pollution measures are undertaken first, levied against the most politically vulnerable targets. See James E. Krier, The End of the World News, 27 LOY. L.A. L. REV. 851, 853 (1994).

103. See 139 Cong. Rec. H2997, 3002-03 (1993) (statement of Rep. Coyne).

104. See, e.g., Dawn Erlandson, The BTU Tax Experience: What Happened and Why it Happened, 12 PACE ENVTL. L. REV. 173, 175 (1994) ("describing the BTU tax as "brilliantly conceived in every way."); Daniel A. Lashof, The BTU Tax: A Revenue Source That Fights Pollution, 59 TAX NOTES 1271 (1993).

105. Henry Lee, The Political Economy of Energy Taxes: An Assessment of the Opportunities and Obstacles, 12 PACE ENVTL. L. REV. 77, 77 (1994). 
a coalition of energy providers, energy consumers, ${ }^{106}$ and legislatorsconcerned about the regressive nature of the tax ${ }^{107}$ Bundling a BTU tax with sugar pills for those adversely affected proved to be unexpectedly difficult. ${ }^{108}$ As Thompson noted, egocentric interpretations of fairness can even blind stakeholders to solutions that would inure to their benefit. ${ }^{109}$ The BTU tax was presented as a revenue-raising alternative to a gasoline tax, which is considered to be unfair toward automobile-dependent rural populations, ${ }^{110}$ and a carbon tax, which is considered to be unfair to coal-miners and coal-mining interests, ${ }^{111}$ and yet the BTU tax failed. Despite the view of many economists that energy taxes would be an effective method of raising revenues ${ }^{112}$ and reducing environmental harms associated with fossil fuel extraction and combustion, ${ }^{113}$ the BTU tax failed because it was unfair to too many stakeholders. Thus, while relatively low-cost ways to raise revenue and reduce pollution may exist, they may suffer from political realities that render them infeasible. Part of the infeasibility stems from our overwrought desire to be fair and avoid harming anyone's interests when changing policy, a propensity that is made necessary by egocentrism.

One need not look far to find other examples of egocentrism in politics. Egocentrism makes it harder to identify and implement low-cost opportunities to reduce pollution. Fairness-thinking indulges egocentrism, and tends to make the possible impossible.

\section{Identifiability And The Focus On The Polluter}

The focus on fairness has ill-served the environmental side, dragging the debate and policy analysis toward a focus on the polluter, where the

106. See id. at 78.

107. See Editorial, The Bouncing Tax Burden, WASH. POST, June 14, 1993, at A18; Jackie Calmes, Doing the Deal: The Deficit-Reduction Conference: White House, Democrats Seek to Boost Support for Compromise Economic Plan, THE WALL ST. J., July 16, 1993, at A10.

108. Calmes, supra note 107 (noting Rep. Charles Rangel's price for supporting the President's BTU tax).

109. See Thompson, supra note 99, at 244.

110. White House Budget Director Leon Panetta remarked that the President was attempting to introduce a "broad-based" energy tax, "in contrast to a gasoline tax that would tend to hit rural areas harder." Sam Fulwood, Budget Bill May Bypass Panel, Bentson Says, L.A. TIMES, June 7, 1993, at 1.

111. Amy C. Christian, Designing a Carbon Tax: the Introduction of a Carbon-Burned Tax, 10 U.C.L.A. J. ENVTL. L. \& POL'Y 221, 277 (1992).

112. John E. Chapoton, The Clinton Tax Plan: The Tax Policy Pendulum Swings Back, 50 WASH. \& LEe L. REV. 449, 454 (1993); Robert W. Hahn, United States Environmental Policy: Past, Present and Future, 34 NAT. Res. J. 305, 344 (1994); Alan S. Miller, Energy Policy From Nixon to Clinton: From Grand Provider to Great Facilitator, 25 ENVTL. L. 715, 724-25 (1995); Lee, supra note 105 , at 77.

113. Douglas A. Kysar, Law, Environment, and Vision, 97 Nw. U.L. REV. 675, 678 (2003); William L. Buzbee, Urban Sprawl, Federalism, and the Problem of Institutional Complexity, 68 FORDHAM L. REV. 57, 84 n.119 (1999). 
polluter enjoys a vast advantage in information over environmental advocacy groups. When arguing over what may be fairly required of regulated industries, information on marginal pollution abatement costs and the availability of substitutes is almost exclusively controlled by the regulated industries. ${ }^{114}$ Calls for more stringent regulation are thus invariably met with irrefutable assertions by regulated industries of infeasibility and unfairness. As well, the preponderance of resources lies on the regulated entity side, as most environmental lawyers represent regulated entities, not enforcement agencies or environmental organizations. ${ }^{115}$

But more fundamentally, a fairness orientation inevitably biases environmental policymaking against the environmental side. The costs of pollution control measures fall on identifiable persons-identifiable coal miners, loggers, and factory workers who will ostensibly lose their jobs because of pollution control measures. These sacrifices are difficult to make, especially when the benefits of pollution control measures inure to the benefit of unidentifiable persons-future generations, persons sickened by pollution or persons whose illnesses would be aided or cured by as-yet undiscovered natural medicines. Political actors respond more readily to the needs of identifiable persons, especially when they are constituents. Consider this missive from former Sen. Slade Gorton of Washington:

That preservation [of northern spotted owls by law] has wreaked incomprehensible havoc on timber families who have had to live with prolonged uncertainty about their futures. All indices of human despair have gone through the roof in these communities: child abuse, spousal abuse, alcohol and substance abuse, divorce, adolescent depression and suicide attempts, bankruptcies, and illness. All of these have been exacerbated by the terrible and unintended consequences of the Endangered Species Act of 1973. ${ }^{116}$

Gorton's attack on the Endangered Species Act strikes a familiar theme. Politicians whose constituencies have been disadvantaged by regulation under the Act have always sought to personalize the costs in a way that has disadvantaged proponents of species protection. It is impossible to personalize the benefits of protecting endangered species,

114. For examplc, Census Bureau data on industry compliance costs are derived from surveys administered to the regulated industries themselves. James C. Robinson, The Impact of Environmental and Occupational Health Regulation on Productivity Growth in U.S. Manufacturing, 12 YALE J. ON REG. 387 (1995); see also David M. Driesen, The Societal Cost of Environmental Regulation: Beyond Administrative Cost-Benefit Analysis, 25 ECOLOGY L. Q. 545 (1997), Lynn E. Blais, Beyond Cost/Benefit: The Maturation of Economic Analysis of the Law and its Consequences for Environmental Policymaking, 2000 U. ILL. L. REV. 237 (2000).

115. Manaster, supra note 18, at 922.

116. 138 CONG. REC. S16,941 (1992) (statement of Sen. Gorton). 
because the benefits are so poorly understood and widespread. Nothing that proponents of environmental regulation have come up with so far seems to trump the sympathy that people feel for their identifiable fellow citizens that purportedly lose their jobs due to environmental regulation. The same rhetorical strategy of personalizing job loss due to environmental regulation has been used with great success by the automobile industry, ${ }^{117}$ the coal mining industry, ${ }^{118}$ and of course, the farm industry. ${ }^{119}$

Consider also the 1978 Love Canal toxic waste disaster that galvanized not only environmental activists, but the United States Congress. Widespread news coverage of the incident was followed by swift passage of the Comprehensive Environmental Response, Compensation and Liability Act of 1980 ("CERCLA"), or the "Superfund" law, ${ }^{120}$ which provides a strong liability scheme and remedial relief for hazardous waste problems. In the ensuing years, the moral imperative behind CERCLA has weakened. Stories of contaminated hazardous waste disposal sites have lost their newsworthiness, and the identifiability of the hazardous waste disposal problem to specific communities has been lost. Occasionally, a story as compelling as the Erin Brockovich story ${ }^{121}$ and the Woburn, Massachusetts story ${ }^{122}$ (both of which were made into successful movies) arise, and the identifiability problem is temporarily overcome-specific individuals face environmental risk and death. And yet, the interest in such stories eventually fades, and it becomes easy to forget that these cases are only the tip of an iceberg of less identifiable victims that receive considerably less attention.

Lisa Heinzerling argues that the identifiability of prospective victims does not increase the level of sacrifice that we, as a society, are willing to undertake to avoid harming the prospective victims. ${ }^{123}$ As evidence for this claim, Heinzerling cites the example of the extraordinary measures

117. See, e.g., Joe Miller \& Jeff Plungis, CAFE Fight Unites Carmakers, UAW, DETROIT NEwS, Feb. 26, 2002, at A1 ("The grass-roots campaign, held in cooperation with the United Auto Workers union, reached GM's pickup truck plant in Pontiac Monday morning. Speakers at the rally included top GM executives, UAW leaders and Sen. Carl Levin, D-Mich. 'The stage is set in Washington, D.C., for (union) jobs to be legislated away,' UAW Vice-President Richard Shoemaker told hundreds of GM workers at the Pontiac rally.").

118. BRYNER, supra note 34, at 105 ([During the floor debates over the Clean Air Act Amendments,] "Byrd held the floor during much of the week of March 19, describing in detail the lives and deaths of coal miners.").

119. See supra note 73.

120. 42 U.S.C. $\$ \S 9601-9675$ (2003).

121. The popular 2000 movie that chronicled the lawsuit over the release of a carcinogen that led to a cluster of illnesses and deaths near Hinkley, California.

122. Chronicled in the book $A$ Civil Action, by Jonathan Harr (1996).

123. Lisa Heinzerling, The Rights of Statistical People, 24 HARV. ENVTL. L. REV. 189, 196$97(2000)$. 
that we undertook in response to a spate of Tylenol poisonings in the early $1980 \mathrm{~s} .{ }^{124}$ Heinzerling also cites the extraordinary measures that we seem to be willing to undertake to minimize the risk of terrorism. ${ }^{125}$ It seems more likely, however, that the populace is reacting to the extraordinary newsworthiness of such events. Then-judge Stephen Breyer observed in his provocative book, Breaking the Vicious Circle, that "[p]eople react more strongly, and give greater importance to events that stand out from the background.... We more likely notice the (low-risk) nuclear waste disposal truck driving past the school than the (much higher-risk) gasoline delivery trucks on their way to local service stations." 126 That this seems true today vindicates Justice Holmes's observation decades ago that people tend to think "dramatically, not quantitatively." 127 The problem for environmental law is that death by pollution is pedestrian and unworthy of news coverage.

The hypothesis that greater victim identifiability leads to a greater willingness to avoid harm is consistent with research in the psychology and decision science field. A recent study found that subjects in a controlled experiment were much more willing to aid identified victims than unidentified victims. Subjects were given $\$ 10$ to begin a chance game, in which $\$ 10$ was taken away randomly from half of them. The subjects that were allowed to keep their $\$ 10$ were given the option of sharing their $\$ 10$ with someone who had lost hers. The study found that subjects were much more likely to share their $\$ 10$ with an identified subject that had lost her $\$ 10$, than with an unidentified one. ${ }^{128}$

The identifiability problem highlights one of the biggest problems with our fairness-oriented way of thinking about environmental law, because this way of thinking begets the question, "fairness to whom?" Those on the environmental-protection side have never been able to answer that question as convincingly as those on the regulated side.

\section{Uncertainty}

Calls for scientific certainty have often been the bane of environmental protection. The causal link between environmentally harmful activities and harm to humankind has never been perceived to be as certain as the connection between environmental protection and economic harm to regulated industries. Regulated industries have been

124. Id.

125. Id.

126. STEPHEN BREYER, BREAKING THE VICIOUS CIRCLE 35 (1993).

127. Id. at 37.

128. Deborah A. Small \& George Loewenstein, Helping " $A$ " Victim or Helping "THE" Victim: Altruism and Identifiability, 26 J. OF RISK \& UNCERTAINTY 5 (2003); see also Karen E. Jenni \& Geoge F. Loewenstein, Explaining the Identifiable Victim Effect, 14 J. OF RISK \& UNCERTAINTY 235 (1997). 
much more successful than environmental organizations at mixing science and advocacy and at arguing their case to political actors. Consequently, political actors have focused upon the purportedly certain economic harms rather than the purportedly less certain environmental harms, with the result that fairness to the more diffuse public interest has been shortchanged. Even if the magnitude of the harm is large, the lower probabilities seem to have a greater influence on how the possibility of that harm is treated.

Again, a more fundamental human nature mechanism is at work: issues involving scientific uncertainty will always be resolved in a way that is biased against environmental regulation. In the face of scientific uncertainty regarding future environmental problems, behavioral research has shown that people will engage in wishful thinking. ${ }^{129}$ Thompson has noted that this form of cognitive bias has hindered solutions to common-pool resource problems for lack of recognition that there is even a problem that needs to be solved, even by resource users completely dependent upon the resource. ${ }^{130}$ This should surprise few who are familiar with the response of denial in the face of troubling realities. If anything, this bias is even stronger in the broader context of environmental law; a general populace that feels only an indirect dependence upon environmental integrity will tend to pay even less attention to an environmental problem than a group of resource users completely dependent upon a troubled resource.

How do we introduce some consistency into the way that we deal with different types of risks? How do we ferret out spurious claims of fairness? What about fairness to the general public and to future generations, which benefit from environmental protection, or to American taxpayers, who subsidize some of the most environmentally damaging activities? How is the cause of environmentalism to be argued if the cause of fairness has not adequately represented the public interest? The answer is that another mode of argument and analysis is needed. When choosing from among competing versions of fairness, we have often made bad choices. American taxpayers and environmental organizations seeking to protect ecological values have generally not been as successful at invoking fairness as have regulated industries. A change in the nature of the debate is needed to illuminate the magnitude of the public interest. More and richer criteria are needed to make environmental law debates more meaningful and effective.

129. See Thompson, supra note 99 , at 258-59.

130. See id. 


\section{WHAT IS EFFICIENCY IN ENVIRONMENTAL LAW?}

It is easy to overstate the practical differences between fairness and efficiency, as these notions often address the same ethical problems and often prescribe the same outcomes. ${ }^{131}$ Efficiency and fairness concepts share some of the same moral underpinnings. ${ }^{132}$ It has been observed by no less an authority than Rawls that utilitarianism - the forerunner of efficiency-combined with an assumption that people generally have a declining marginal utility of wealth, ${ }^{133}$ provides a "prima facie case for equality," since in a world of identical persons, inequalities would yield something less than the maximum amount of utility. ${ }^{134}$ Indeed, utilitarianism and efficiency concepts are sometimes expressed as versions of fairness. ${ }^{135}$

But classic utilitarians ${ }^{136}$ saw utilitarianism not as an alternative to fairness, but as the basis of fairness, ${ }^{137}$ while non-utilitarians have argued

131. Rawls has acknowledged his commonalities with utilitarians, noting that "[j]ustice is a kind of efficiency." See Rawls, supra note 27 , at 184 . Dworkin has acknowledged the critical role of markets in achieving an "equality of resources" that takes account of individual preferences. See Dworkin, supra note 47 , at 284 . In a market economy, and assuming an equal starting endowment of talents and wealth, allocative efficiency "simply is fairness." See id. at 305 (emphasis added).

132. For example, Posner has argued that consent is the basis for Paretian concepts. Consent can be readily implied in Pareto Superior transactions, since no one is made worse off. Richard A. Posner, The Ethical and Political Bases of the Efficiency Norm in Common Law Adjudication, 8 HOFSTRA L. REV. 487, 488-90 (1980). Consent must be implied in Kaldor-Hicks efficient transactions because of the possibility that some parties may be made worse off. Posner solves this problem by imputing consent from "ex ante compensation," in the form of higher ex ante welfare due to the more efficient social arrangements induced by efficient rules. Thus, even if a party is worse off ex post, consent can be implied from an individual's greater ex ante expected utility. Id. at 491-97. But see Jules L. Coleman, The Normative Basis of Economic Analysis: A Critical Review of Richard Posner's The Economics of Justice, 34 STAN. L. REV. 1105, 1117-30 (1982) (denying that compensation, ex ante or ex post, even if it exists, constitutes consent).

133. Declining marginal utility of wealth means that as wealth increases, each increment of wealth provides less of an increase in utility. MARK SEIDENFELD, MiCROECONOMIC PREDICATES TO LAW AND ECONOMICS 72 (1996).

134. See Rawls, supra note 27 , at 185 . In a zero-sum world in which one person's greater wealth is at the expense of at least one other person, and in a world in which everyone has a declining marginal utility of wealth, inequalities would be inefficient because a rich person's greater wealth provides a smaller increase in utility than a poor person's the decrement of utility. Economists have long sought to find quantitative measures of inequality. See, e.g., Corrado Gini, Measurement of Inequality of Incomes, 31 ECONOMIC JOURNAL 124 (1921) (discussing the author's famed "Gini coefficient" that measures inequality of incomes); Kenneth L. Wertz, The Measurement of Inequality: Comment, 69 AM. ECON. REV. 670 (1979) (describing the "Gini coefficient" of income inequality); Amartya Sen, Poverty: An Ordinal Approach to Measurement, 44 ECONOMETRICA 219 (1976).

135. Posner states that utilitarianism is a "theory of both personal morality and social justice." Richard A. POSNER, THE ECONOMICS OF JUSTICE 51-52 (1981); $c f$. Hugo A. Bedau, Justice and Classical Utilitarianism, in JUSTICE 284-85 (Carl J. Friedrich \& John W. Chapman eds., 1963).

136. Among the classical utilitarians, who believed utility to be a more fundamental concept than fairness or justice, were Hume, Bentham, Mill and Sidgwick. See Bedau, supra note 135, at 284-88. 
that fairness is the more fundamental concept, and that the concept of utility is incomplete. ${ }^{138}$ And modern efficiency advocates have, if anything, emphasized differences rather than similarities between efficiency and fairness. Kaplow and Shavell have noted that fairness concepts tend to be non-consequentialist in nature-that application of fairness principles can be correct even in light of adverse consequences ${ }^{139}$-and that fairness rules tend to be ex post in nature, while efficiency rules are determined ex ante. ${ }^{140}$

For a policymaker, the difference is not just academic. Efficiency is more susceptible of elucidation than notions of justice and fairness, ${ }^{141}$ because there are only two accepted indices of efficiency: utility and wealth. The reduction of decision criteria down to a single index is what students of government find so appealing, and what ethicists find so appalling. ${ }^{142}$ Reducing decisions down to an index may understate or overstate some of the possible considerations, but it allows one to make principled choices between policy proposals. Debate about policy proposals focuses upon the more answerable questions of the appropriateness and accuracy of analysis, rather than the unanswerable questions that are posed when competing arguments of fairness are raised. Again, like most advocates of efficiency analysis, I argue not for an exclusion of fairness considerations, but for a greater emphasis on efficiency analysis to help sharpen and clarify issues.

Utility concepts include Pareto Superiority and Potential Pareto Superiority or Kaldor-Hicks Efficiency. Pareto Superiority describes a state in which there is unambiguously higher social utility than another state, and hence greater efficiency. One state of the world-call it A-is said to be Pareto Superior to a second state of the world-call it B-if, from state $\mathrm{B}$, a series of exchanges can take place, each of which makes at least one party better off while not making any party worse off, until the

137. Id. at 288; see also John Stuart Mill, On Utiliarianism, in 43 GREAT Books OF THE WESTERN WORLD 445-76 (William Benton, Robert Maynard Hutchins, ed., 1952).

138. Non-utilitarians charge that utilitarianism fails to account for the fundamental "moral relations" among people. See Chapman, supra note 27 , at 149 . To sharpen this point, nonutilitarians have repeatedly raised the question of whether nefarious preferences such as bigotry are allowed to count in utility functions. For example, Dworkin and others have asked if, under utilitarianism, the preferences of bigots should be taken into account in evaluating social policy. See Ronald Dworkin, What Is Equality? Part 1: Equality of Welfare, 10 PHIL. \& PUBL. AFF. 185, 198 (1981). Dworkin has also posed the question of whether those with frivolously expensive tastes should receive more. See id. at 189.

139. KAPLOW \& SHAVELL, supra note 22 , at 47.

140. Id. at 48-49. A notable exception is Rawls's theory of justice, which posits decisions made by individuals behind a veil of ignorance. JOHN RAWLS, A THEORY OF JUSTICE 19 (1971).

141. Utilitarians argue that because of the vague and indeterminate nature of fairness and justice, these concepts were prone to misuse by legislators for self-serving "sympathy and antipathy." See Jeremy BenTham, THE Theory OF Legislation 14 (C.K. Ogden ed., Harcourt, Brace 1931).

142. See, e.g., MARK SAGOFF, THE ECONOMY OF THE EARTH 8-9 (1988). 
parties have reached state $A .{ }^{143}$ The problem with Pareto Superiority is that policy measures are never such that no one is made worse off - there are always losers in any policy proposal, some of which we nevertheless must carry out. A more practical efficiency notion is thus Potential Pareto Superiority, or Kaldor-Hicks Efficiency, ${ }^{144}$ which posits that a policy is worth carrying out if, after the policy is implemented, a series of transfers could take place so that no one is made worse off, regardless of whether the transfers are actually made. However, even this efficiency concept is unworkable, since like Pareto Superiority, it is based upon individual utilities, which are unmeasurable ${ }^{145}$ Economists, led by Richard Posner, have thus turned to Wealth Maximization. ${ }^{146}$ Individual policy proposals are evaluated typically by means of a cost-benefit analysis, which determines whether the policy will increase monetized benefits more than costs. ${ }^{147}$ Somewhat related to all of these notions is the broader and more abstract notion of welfarism, which seeks to maximize social utility, by positing the existence of a social welfare function or utility function. ${ }^{148}$

Because utilities are unmeasurable, efficiency in environmental law must as a practical matter amount to a general policy of wealth maximization. As noted above, I do not advocate replacing fairness concerns with efficiency concerns. ${ }^{149}$ I thus do not propose that wealth maximization be the sole basis on which environmental decisions are made. My proposal is only that we use wealth maximization as a way to elevate efficiency considerations, so that they play a greater role in environmental decision-making.

Wealth can be construed broadly, and involves the quantification of many environmental goods that are not priced. In addition to tangible and measurable costs, such as the costs of human sickness brought on by pollution and lost work productivity, loss of wealth encompasses less measurable losses, such as risk of loss of life, a considerably more controversial topic. ${ }^{150}$ Beyond human health concerns, losses of wealth also include losses of natural resources and the ecosystem services they provide. Wetlands provide flood control and water filtration services, which are measurable by considering the cost of constructing equivalent

143. POSNER, supra note 26 , at 13 (2003).

144. Id.

145. Others add the objection that the Kaldor-Hicks notion violates the basic economic assumption of transitivity. Jules L. Coleman, Efficiency, Utility, and Wealth Maximization, 8 HOFSTRA L. REV. 509, 518-20 (1980).

146. POSNER, supra note 135 , at vii.

147. POSNER, supra note 26 at 396-97.

148. See supra note 25. Welfarism is distinguishable from Kaldor-Hicks efficiency in that the latter is predicated on individual utility functions.

149. See supra text accompanying note 11.

150. See, e.g., Frank Ackerman \& Lisa Heinzerling, Pricing the Priceless: Cost-Benefit Analysis of Environmental Protection, 150 U. PENN. L. REV. 1553 (2002). 
facilities that could perform these services. But wetlands provide wealth in a number of other ways that are more difficult to measure: as habitat for fish and wildlife, as buffers for transitions between different ecosystems, as sites for a variety of recreational activities, as aesthetic amenities, and simply as important parts of a diverse land and seascape. ${ }^{151}$ There are a number of ways of estimating these non-use values, of which the survey-based contingent valuation methodology is the most common. ${ }^{152}$ Environmentalists and environmental law scholars often object to the methodological problems with contingent valuation, or simply reject outright the idea of valuing natural resources. ${ }^{153}$ Yet, it would be uncontroversial to say that humankind would be "impoverished" if a dam were constructed that would flood the Grand Canyon, as was planned in the $1960 \mathrm{~s} .{ }^{154}$ It seems reasonable to confront the question of exactly how impoverished we would be by such a foolish plan.

Cost-benefit analysis is clearly an important tool for accomplishing efficiency, but the efficiency agenda in environmental law is much broader. Efficiency in environmental law also calls for programs that achieve economic or environmental gains, often by trading. This would include programs that issue transferable rights to pollute, fish, or develop land. ${ }^{155}$ Greater efficiency is believed to be accomplished by the free exchange of these rights, which economists believe will flow to their highest and best use, ensuring that the amount of pollution, fishing, extraction or development permitted is undertaken with a minimum of cost. Efficiency programs might also involve trading between a regulatory agency and a regulated entity. In theory, an appropriate trade could allow the regulated entity to achieve an economic gain and the regulated agency to achieve an environmental gain. Greater efficiency could also be achieved by taxation of polluting, fishing, extracting, or land development. Economists have long advocated the use of "Pigouvian" taxes, which are levied upon a quantity of pollutant or a unit of

151. Such intangible values are sometimes referred to by economists as passive use values, referring to the fact that while these resources may not be directly "used," they are nevertheless valuable to persons who deem their mere existence important. See Shi-Ling Hsu \& John Loomis, A Defense of Cost-Benefit Analysis for Natural Resource Policy, 32 ENVTL. L. REP. 10,239, $10,241(2002)$.

152. Dale B. Thompson, Valuing the Environment: Courts' Struggles With Natural Resource Damages, 32 ENVTL. L. 57, 58 (2002).

153. See, e.g., Brian R. Binger et al, The Use of Contingent Valuation Methodology in Natural Resource Damage Assessments: Legal Fact and Economic Fiction, 89 Nw. U. L. REV. 1029, 1030 (1995); James L. Nicoll, The Irrationality of Economic Rationality in the Restoration of Natural Resources, 42 ARIZ. L. REV. 463, 481 (2000); SAGOFF, supra note 142, at 24-49.

154. Alexander Cockburn, The Militant Legacy of Nature's Warrior, SEATTLE TIMES, Nov. 9,2000 , at B9.

155. See infra § V.B. 
environmental harm. ${ }^{156}$ Like a system of transferable rights, Pigouvian taxes are meant to internalize "externalities," side-effects such as the environmental harm generated by these activities, that are not properly taken into account by the polluter, fisher, miner, or developer. ${ }^{157} \mathrm{By}$ internalizing these harms, it is hoped that we can obtain an efficient (and socially desirable) decrease in the amount of production and pollution in that industry.

It is important to note what efficiency is not. Regulated industries have often made claims that resemble efficiency claims by emphasizing the costs of regulation. In many cases they are justified in doing so. However, efficiency-thinking is not a one-sided analysis of how to minimize the costs of environmental compliance. The costs of environmental compliance constitute only half of the inquiry; the benefits side of environmental compliance, though more difficult to measure than the costs, is the other and equally important half. It is thus not efficiencythinking at all to consider only the costs of regulation, as some statutes seem to mandate. "Feasibility-limited" regulation, which requires regulation up to the point that is deemed economically or technologically feasible, considers only the cost side of compliance. ${ }^{158}$ True efficiencythinking considers both the costs and the benefits of pollution abatement techniques.

156. French economist Alfred Pigou pioneered the idea that through taxes and subsidies, government could introduce incentives to encourage fewer activities that generated negative externalities, and more activities that generated positive externalities. In other words, through taxes and subsidies, the government could equate the private marginal cost and the social marginal cost of an activity, and the private marginal benefit and social marginal benefit of an activity. See A.C. Pigou, The Economics of Welfare 131-137 (3d ed. 1929). Taxes that reflected the extent of negative externality thus became known as "Pigouvian" taxes. BAUMOL \& OATES, supra note 63, at 21-23; Jonathan Baert Wiener, Global Environmental Regulation: Instrument Choice in Legal Context, 108 YALE L. J. 677, 707-708 (1999). Calabresi has restated this Pigouvian notion by developing a theory of "enterprise liability," in which enterprises should "bear the costs that they engender." Guido Calabresi, Some Thoughts on Risk Distribution and the Law of Torts, 70 YALE. L. J. 499, 500 (1961).

157. An externality is an effect of a decision, on a party other than the decisionmaker, that the decisionmaker does not take into account. POSNER, supra note 26 , at 71 .

158. See PERCIVAL, supra note 7, at 476-477. One example is the regulation of hazardous air pollutants, which requires the promulgation of standards reflecting the "maximum degree of reduction in emissions of the hazardous air pollutants ... taking into consideration the cost of achieving such emission reduction, and any non-air quality health and environmental impacts and energy requirements." 42 U.S.C. $\$ 7412$ (d)(2) (2003). Another is the Safe Drinking Water Act, which requires EPA to establish Maximum Contaminant Levels, and Maximum Contaminant Level Goals, the former of which are actually the binding regulations, and are "as close to the maximum contaminant level goal as is feasible," 42 U.S.C. $\$ 300 \mathrm{~g}-1$ (b)(4)(B) (2003), although the statute also directs EPA to consider "quantifiable and non-quantifiable health risk reduction benefits." Id. §300g-1(b)(3)(C). 


\section{HOW MIGHT EFFICIENCY HELP?}

The public interest in environmental law has often been ill-served because it butts up against private interests that are quite large and intensely concentrated in a small group of people, such as regulated or subsidized industries. Fairness-thinking, especially by lawyers, has protected these minority values. So ingrained is this mode of politics that it has generated assumptions about the value of these programs. Efficiency-thinking is frightening, because it challenges assumptions we have made about the merits of these minority values, but it should make us think seriously about the gains that we are passing up.

\section{A. Efficiency Can Help Remedy the Problems Posed By Fairness- Thinking}

The public interest in environmental law has been ill-served for the reasons discussed above in Section II: rent seeking, the difficulty of finding low-cost ways to reduce pollution, and problems with identifiability of victims and uncertainty of science. Fairness rhetoric has been unsuccessful in overcoming these problems, and efficiency rhetoric and efficiency-thinking offer at least a promising alternative.

Fairness-thinking has at least facilitated, if not encouraged, the disguise of rent-seeking in the cloak of fairness. More efficiency-thinking and less fairness-thinking may not eliminate the market for political favor, but it may at least move the debate in a direction that is more oriented towards the public interest. A number of cost-benefit analyses of the Clean Air Act have indicated that the costs of regulation are dwarfed by the monetized benefits of regulation. ${ }^{159}$ What do we have to show for

159. A 1997 cost-benefit analysis of the Clean Air Act estimated that while compliance costs over the years 1970 to 1990 totaled $\$ 523$ billion, the benefits totaled $\$ 22.2$ trillion. EPA, FINAL REPORT TO CONGRESS ON BENEFITS AND COSTS OF THE ClEAN AIR ACT, 1970 TO 1990, ES-2 to ES-8 (1997), available at http:/www.epa.gov/air/sect812/812exec2.pdf [hereinafter 1997 Report]. A follow-up report estimated that from 1990 to 2010 , total compliance costs would be $\$ 27$ billion per year, and total benefits $\$ 110$ billion per year. EPA, FINAL REPORT TO CONGRESS ON BENEFITS AND COSTS OF THE CLEAN AIR ACT, 1990 TO 2010, iii tbl.ES-1 (1999), available at http:/www.epa.gov/air/sect812/1990-2010/fullrept.pdf [hereinafter 1999 Report]. An analysis of Title IV of the Clean Air Act, the acid rain program, estimated that human health benefits alone ranged from $\$ 12$ billion to $\$ 78$ billion in the United States, and from $\$ 290$ million to $\$ 1.9$ billion in Canada. Lauraine G. CHestnut, Human Health BENEFITS From Sulfate Reduction UNDER TITLE IV OF THE 1990 ClEAN AIR ACT AMENDMENTS S-4 tbl.S-2, S-5 tbl.S-3 (1995), available at http:/www.epa.gov/airmarkets/articles/healtheffects/index.html. This benefit estimate does not even include the ecological benefits of reduced $\mathrm{SO}_{2}$ emissions, which have wreaked havoc on Northeastern lakes and rivers. Estimates of the cost of the program, in the meantime, have been on the order of $\$ 800$ million. A. DENNY ELLERMAN, ET AL., MARKETS FOR CLEAN AIR 228-31 (2000) (\$726 million for 1995); Curtis Carlson et al., Sulfur Dioxide Control by Electric Utilities: What are the Gains From Trade? 108 J. POL. ECON. 1292, 1318 (2000) (estimating cost of $\$ 832$ million for 1995) [hereinafter RFF Report]; see also ENERGY Info. Admin., U.S. DeP'T Of ENERGy, The EFFEcts of Title IV OF THE CleAn Air ACT 
these analyses? Quite possibly, these analyses have contributed to a bipartisan recognition for the need to reduce emissions further. Three competing proposals currently before the United States Senate, including President Bush's "Clear Skies" proposal, call for a reduction in permitted pollutant levels. ${ }^{160}$ While there is considerable wrangling over which of these proposals will ultimately be the adopted pollution reduction bill, it seems incredible that there should be such a broad recognition of the need for a bill, even if it means the imposition of very large costs upon dozens of industries, such as the powerful automobile industry and the electricity generating industry. ${ }^{161}$ A pessimist might object that there is no evidence that the bipartisan recognition of more stringent pollution regulation is attributable to cost-benefit analyses. But what else has emerged in the last twelve years that warrants more stringent regulation? In the wake of the 1990 Clean Air Act Amendments that mandated a fifty percent reduction in sulfur dioxide emissions, how is it that the electricity generation industry seems willing to accept a further reduction in sulfur dioxide emissions and further controls on other pollutants emitted by power plants? ${ }^{162}$

This Clean Air Act example also illustrates how efficiency analysis can help identify additional low-cost ways to reduce pollution. The legislative and political stalemate seems to suggest that environmental problems are more intractable now than they were in the 1970s, when Congress passed most of the environmental statutes. Efficiency analysis may be the magnifying glass needed to identify hidden efficiencies in the form of pollution reduction. In the case of the Clean Air Act, the opportunities are quite large. But we only know this because cost-benefit analyses have highlighted the huge gaps by which benefits outstrip costs in terms of air pollution regulation.

More explicit considerations of efficiency can also overcome identifiability problems that plague environmental regulation. Whenever the Robert Byrds and the Slade Gortons of the Congress appeal to American sympathies for constituents that would lose their jobs, it is

AMENDMENTS OF 1990 ON UTILITIES: AN UPDATE, available at http://www.eia.doe.gov/cneaf/electricity/clean_air_upd97/exec_sum.html.

160. Sen. Jeffords (I-VT) is the lead sponsor on S. 366, to limit emissions of sulfur dioxide, nitrogen oxide, mercury and carbon dioxide. Clean Power Act of 2003, S. 366, 108th Cong. (2003). President Bush's proposal imposes limits on three of the four pollutants (excluding carbon dioxide). Clear Skies Act of 2003, S. 485, 108th Cong. (2003). Sen. Carper (D-DE) is the lead sponsor on a compromise bill that also limits emission on four pollutants, but at less stringent levels and on a less stringent timetable. Clean Air Planning Act of 2003, S. 843, 108th Cong. (2003).

161. The four pollutants addressed by the Jeffords bill and the Carper bill are pollutants emitted by coal-fired power plants. See S. 366; S. 843.

162. Most of the electricity generation industry is supporting the Clear Skies initiative. Steve Cook, Industry Endorsements for 'Clear Skies' Increase After Briefing by White House, 34 ENVTL. REP. 1711, Aug. 1, 2002. 
necessary to remind the public of the asthmatic children and premature mortalities caused by coal combustion, ${ }^{163}$ or the benefits yielded by the nearly-extinct Pacific Yew tree that has produced the breast and ovarian cancer treatment taxol, ${ }^{164}$ or the benefits provided by the rosy periwinkle, which produces a treatment for Leukemia and Hodgkin's disease. ${ }^{165}$ Yet this is not enough. Such comparisons do not address the slippery slope problem that arises when opponents of environmental regulation ask: how much is enough? Should we ban logging altogether in the hope that some obscure tree, plant, fly, or lizard may hold the cure to some rare disease? Are environmentalists prepared to put thousands of identifiable people out of work for such vain hopes? Cost-benefit analysis provides an answer to the question of how much is enough. Perhaps more importantly, it helps to overcome the identifiability problem by expressing identifiable costs and unidentifiable benefits in the same metric.

The process of conducting cost-benefit analysis also forces policymakers to identify and catalog all of the consequences of pollution, and bundle them together under the category of "benefits of regulation." The momentous task of performing cost-benefit analyses under the Clean Air Act has caused researchers to inventory the numerous ways in which air pollution imposes costs upon society. The costs of air pollution include premature mortality, disability inducement, and illness; loss of recreation due to impaired air quality and acid deposition; impaired visibility; ecological effects due to acid deposition, impaired air quality, and stratospheric ozone layer depletion; damage to fish and wildlife habitat; and other effects. ${ }^{166}$ While this cataloging of effects could certainly occur without cost-benefit analysis, the bringing together of all of these effects highlights the manifold ways in which air pollution harms us, and combines them into a single number. It might seem distasteful to express all of the human pains and losses as a number. Some take issue with the accuracy with which these pains and losses are quantified. But how else are we to aggregate all of the different harms from pollution? Monetization may not be ideal, but it provides a metric that can be applied to a variety of valued goods.

Some find the idea of monetization distasteful. Heinzerling argues that the very notion of a "statistical life" downplays the reality that

163. See supra note 80 .

164. See UnIV. OF MD. MEd., BREASt CANCER: ABout TAXOL, at http://www.umm.edu/breast/

taxol.htm (last updated May 14, 2003).

165. Erin Streff, Curing Lessons Learned From Plants, NAT'L GeOGRAPHIC NEWS, Mar. 14, 2001, at http://news.nationalgeographic.com/news/2001/03/0314_plantsheal.html.

166. See 1999 Report, supra note 159 , at vii to xiv (showing Table of Contents listing some of the studied effects). 
people die from environmental risks. ${ }^{167}$ The opposite is true. Cost-benefit analysis ameliorates the identifiability problem by focusing our attention on the fact that people actually die from pollution. Cost-benefit analysis focuses us on the decisions we implicitly make - how much risk should we tolerate, and how much wealth are we willing to forego to reduce the risk of loss of life? The answer is not, as some would like to believe, infinity. But by failing to acknowledge the existence of tradeoffs, we allow the identifiability problem to poison our implicit decisionmaking by biasing our valuation downwards, toward zero.

Finally, while issues of scientific uncertainty will always make environmental protection seem less compelling than the certain loss of jobs from a fairness-based point of view, cost-benefit analysis can put these uncertainties in perspective. While we may not be able to offer certainty, if we can say with an eight-five percent, seventy-five percent or even a lower level of certainty that specific environmental consequences will occur, it may spur us to act. Thus, for example, although the present loss of jobs to greenhouse gas emissions regulation may seem economically painful, and the benefits of avoiding climate change uncertain, a cost-benefit analysis may place the even more daunting consequences of inaction into perspective.

\section{B. Efficiency Encompasses Values Expressed By Fairness}

Some resistance to efficiency-thinking stems from the failure to recognize that efficiency-thinking captures many values also important to fairness-thinking. As Posner reminds us, many conceptions of fairness in the common law have efficiency underpinnings. Learned Hand's formula for negligence, expressed in the case United States v. Carroll Towing Co.,${ }^{168}$ involves essentially a cost-benefit analysis for determining whether a tort defendant's conduct was reasonable. ${ }^{169}$ According to Posner, the fundamental purpose of contract law is to encourage the "optimal timing of economic activity," in part by creating concepts such as good faith. ${ }^{170}$ And the contract doctrine of duress deals with instances of "situational" monopoly, which is both inefficient and also something that most would consider unfair. ${ }^{171}$ This overlap between familiar concepts of fairness and

167. See Heinzerling, supra note 123 , at $189-92$.

168. 159 F.2d 169 ( $2 \mathrm{~d}$ Cir. 1947). Hand's formula was that if the probability of injury times the extent of injury exceeded the cost of taking precaution against the accident, then failure to undertake the precaution would be unreasonable, and the defendant found liable. Id. at 173.

169. Richard A. Posner, The Learned Hand Formula for Determining Liability, in TORT LAW: CASES AND ECONOMIC ANALYSIS 1-9 (Little Brown 1982).

170. See POSNER, supra, 26, at 94-95.

171. See id. at 115 . 
efficiency should not be surprising, since as noted above, ${ }^{172}$ notions of efficiency and notions of fairness overlap in many ways.

The overlap is notable in environmental law. Fairness arguments in environmental law often reveal efficiency-based underpinnings. For example, Sidney Shapiro and Thomas McGarity have made the argument that a technology-based approach reflects

a considered normative choice about the proper balance between lives and monetary costs. Acknowledging that society cannot vest workers with an unqualified right to an absolutely safe workplace, one may rationally assert that workers do have a right to insist that employers 'do the best they can' to protect human health. ${ }^{173}$

This statement seems eminently reasonable, and an articulate statement of a familiar principle of fairness. However, their next sentence is revealing:

In other words, society might justifiably decide to reduce risky behavior beyond the point indicated by a cost-benefit test. Indeed, society may choose to limit its protection of workers only at the point where the protection would cause industry substantial economic dislocation. ${ }^{174}$

Although Shapiro and McGarity are disavowing cost-benefit analysis as the means for determining a level of worker protection, they are implicitly making a judgment that worker protections more stringent than an employer's "best" are not worth the additional worker protections. That might seem to be a fair result, although we also have very deep reservations about compensating people according to effort. ${ }^{175}$ Making industry do its best, and making the worker assume the remainder of the risk, smacks of a distributive sense of fairness. But what is the basis for that judgment? Shapiro and McGarity are applying their own balancing test. Although one need not accept the monetization of life in order to perform a balancing test, one must ultimately address the question of what considerations are being balanced. Making choices necessarily involves expressing the consequences of the choices in some kind of metric. Balancing tests that tortuously avoid monetization beg the question: how does one know if the risks are worth the benefits? How does one weight the risks and benefits? We are told that we cannot compare apples and oranges. But if we have to, we can find a way of

172. See supra text accompanying notes $131-135$.

173. Sidney A. Shapiro \& Thomas O. McGarity, Not So Paradoxical: The Rationale for Technology-Based Regulation, 1991 DUKE L.J. 729, $743-44$.

174. Shapiro \& McGarity, supra note 173 at 744.

175. Christopher Ake poses the example of compensating a mediocre but earnest violinist who tries as hard to be great as the great violinist Yehudi Menuhin, and in fact believes himself to be as great. It would certainly not be fair to indulge such a delusion. Christopher Ake, supra note 29 , at 80 (1975). 
choosing one. Somehow, we subconsciously develop an index that weights their taste, vitamin $C$ content, caloric value, or any other criteria we choose. Cost-benefit analysis is merely one of several ways of making this process explicit.

What if a cost-benefit analysis reveals that the risks are so high and the solutions so costly that protecting workers may drive the employer out of business? We seem to wish to strenuously avoid this outcome. Behind our reluctance to drive employers out of business (taking at face value employers' claims that closure would be necessary) lies the reluctance to displace workers. This is driven by an expectations sense of fairness to workers. But consideration of the suffering of unemployed workers is not precluded by efficiency-thinking. On the contrary, lost jobs are among the more measurable, identifiable and visible costs we face. Retraining and aid for displaced workers are hardly ideal salves, but efficiency-thinking forces us to confront the difficult question of how valuable the enterprise is when its true costs are assessed.

What if the costs of unemployment and the suffering of the unemployed still fail to outweigh the benefits of ceasing a dangerous enterprise? Such a bleak finding would be discouraging for those affected, but could tell us the uncomfortable truth that the costs of this enterprise, in terms of human health and lives, may just be too high. In fairness terms, labor advocates might argue that it is simply unfair that some are sacrificing their lives so that this enterprise may continue. In efficiency terms, economists might say that the benefits of the enterprise no longer outweigh the high cost of human health and lives. The outcome would be the same. For example, is it plausible to think that we might find a way to keep a manual typewriter factory running and the workers therein employed if it were imposing significant costs in terms of pollution and human risk? This is not such a fanciful question-Senator Gorton's impassioned plea to spare the Pacific Northwest from more lost timber jobs came at a time when even timber companies recognized that the current pace of logging was unsustainable. ${ }^{176}$ While considerations of fairness to loggers created a reluctance to slow the pace of logging, efficiency considerations would have highlighted the increased environmental harm created by logging and how it outweighed the temporary avoidance of job loss. Efficiency-thinking simply requires that the pain of unemployment be considered along with many other factors,

176. The chief economist for timber giant Weyerhaeuser and a timber analyst with Prudential Securities agreed that excess mill capacity was holding lumber prices down during the 1980s. John M. Berry, The Owl's Golden Egg: Environmentalism Could Boost Lumber Profits and Prices, WASH. POST, Aug. 4, 1991, at H1. Weyerhaeuser CEO John Creighton admitted that a shortage of large logs from Weyerhaeuser tree farms has been the leading cause of its Northwest mill closures in the last several years. Weyerhaeuser to Sell Mills, Forests, Columbian, Nov. 29, 1995. 
and not necessarily trump all other factors, as we seem to have been inclined to do in the past.

Finally, requiring regulated entities to do their "best" raises moral hazard problems. Historically, determining whether an employer is doing its "best" has been extremely difficult, particularly when the employer has more information about possible safety improvements than regulators and worker advocacy groups do. EPA, OSHA, and other regulatory agencies and advocacy groups have proven hopelessly inept at overcoming this information asymmetry. We are thus never sure if the alternatives truly are, as regulated industries claim, either to regulate and drive the firm out of business, or not to regulate and allow the firm to continue operating. ${ }^{177}$ Basing regulation upon an employer's best efforts is not only unfair to those who are truly skilled and valuable, but this form of fairness-thinking also cultivates a culture of self-serving excusemaking for not doing what is doable.

An efficiency emphasis may also highlight unfairness suffered by the American public. Farm subsidies, for instance, are unfair to the American taxpayer, to smaller American farmers, and to poverty-stricken farmers in developing countries. ${ }^{178}$ Subsidies to the electricity generation industry, the hardrock mining industry, and the logging industry are similarly unfair to taxpayers, the air-breathing public, as well as Americans with a variety of other values for unspoiled land. ${ }^{179}$ As noted above, ${ }^{180}$ these fairness arguments have not prevailed. It is possible that efficiency arguments would be similarly futile. But the orientation of efficiency arguments guarantees greater attention to these versions of fairness that have historically been bullied aside.

Efficiency-thinking also aptly captures that version of fairness most frequently invoked by the regulated side: the expectations sense of fairness that we should avoid ex post regulation. In conjunction with the voluminous literature on regulatory takings, a number of efficiency arguments have been developed on how and when to regulate private property and potentially frustrate property expectations. Despite decades of a sustained scholarly and judicial effort to develop a coherent and operational takings jurisprudence, the literature and the case law remain muddled. ${ }^{181}$ One formula that has stood the test of time, however, belongs

177. Consider, for example, the oil industry example described in supra note 6.

178. See supra text accompanying notes $73-77$.

179. See supra text accompanying notes 78-85.

180. See supra note 96 .

181. See, e.g., Richard A. EpStein, Takings: Private Property AND the POWER of EMINENT DOMAIN 95-96 (1985) (arguing that virtually every diminution in value caused by governmental intervention should be compensated); WILLIAM A. FISCHEL, REGULATORY TAKINGS 11-12 (1995) (arguing that when land uses deviate too far from "normal" practices, regulation be non-compensable); Lawrence Blume, et al., The Taking of Land: When Should Compensation Be Paid?, 99 Q. J. OF ECON. 71 (1984) (noting that government may suffer from 
to Frank Michelman, who is generally credited with initiating the debate on the efficiency of regulatory takings. ${ }^{182}$ Michelman's utilitarian formula takes explicit account of the "demoralization costs" suffered by uncompensated losers and their sympathizers who fear a similar fate. ${ }^{183}$

Although not easily measurable, the concept of demoralization costs has been influential in environmental and economic policymaking. For example, in policy debates leading up to the planned deregulation of the electricity industry, much discussion took place regarding what should be done with utility stranded costs, capital investments that would be rendered obsolete by the advent of the newer, more efficient facilities that competitive electricity markets would produce. An influential white paper written by three prominent economists warned that indeed, it would not only be unfair to foist competition upon previously regulated utilities and saddle them with stranded costs, ${ }^{184}$ but it would also be inefficient. The paper warned that harsh treatment of utility investments would impose an economic cost upon society by chilling future investment. ${ }^{185}$

It is illuminating that in this white paper on deregulation issues, fairness and efficiency were dual justifications for dealing with the stranded cost problem. Fairness-thinking has focused our attention on regulated parties with expectation interests. Efficiency-thinking can not only capture the fairness concerns that underlie the expectations version of fairness, but capture them in a way that balances these concerns with

the "fiscal illusion" that uncompensated takings do not impose any costs); Steven J. Eagle, The Rise and Rise of "Investment-Backed Expectations," 32 URB. LAW. 437 (2000) (lamenting the intrusion of the economic concept of expectations into property law); Louis Kaplow, $A n$ Economic Analysis of Legal Transitions, 99 HARV. L. REV. 509 (1986) (arguing that risk of changes in legal rules is not substantially different from other types of business risks, and thus should not be generally compensable).

182. See Frank I. Michelman, Property, Utility, and Fairness: Comments on the Ethical Foundations of "Just Compensation" Law, 80 HARV. L. REV. 1165 (1967). Michelman's analysis also highlights the overlap between efficiency and fairness.

183. Defined as the

total of (1) the dollar value necessary to offset disutilities which accrue to losers and their sympathizers specifically from the realization that no compensation is offered, and (2) the present capitalized dollar value of lost future production (reflecting either impaired incentives or social unrest) caused by demoralization of uncompensated losers, their sympathizers, and other observers disturbed by the thought that they themselves may be subjected to similar treatment on some other occasion.

Id. at 1214 .

184. See William J. Baumol et al., Edison Electric Inst., The Challenge for FEDERAL AND STATE REgUlators: TRANSITION FROM REgUlation TO EFFICIENT COMPETITION IN ELECTRIC POWER 33 (1994) (on file with author).

185. Id. at $40-41$. The authors warned of the consequences of prospective investors seeing "legislators or regulators retroactively changing the rules of the game.... Unless government keeps its promises, future investments that rely on regulatory commitments will become more costly or will not be forthcoming." 
other, more public concerns. Efficiency-thinking can accomplish this by determining the appropriate length of a phase-in period for new standards, which would be preferable in any case to the indefinite grandfathering that is currently prevalent in environmental law.

\section{Efficiency Analysis is More Transparent Than Fairness}

Critics of economic analysis argue that cost-benefit analysis is just as easily manipulated as arguments invoking fairness. ${ }^{186} \mathrm{I}$ believe this charge is mistaken. Lisa Heinzerling has devoted much of her distinguished scholarship to identifying what appear to be improprieties and questionable assumptions made in various cost-benefit analyses and other such efficiency-oriented analyses. ${ }^{187}$ But the fact that Heinzerling has been able to challenge these analyses is precisely why efficiency analysis should play a more prominent role in environmental policymaking than at present. According to Heinzerling, OMB official John Graham is often wrong in his analysis. But the nature of efficiency analysis is such that she has been able to identify what she thinks is wrong with his analysis.

Environmental law and policy have certainly been witness to specious uses of economics and of efficiency analysis. When the Clean Air Act was being considered for an amendment in the late 1980's to limit sulfur dioxide emissions from coal-fired power plants, the industry trade group Edison Electric Institute estimated that the cost of compliance with proposed legislation would be $\$ 7.4$ billion per year; ${ }^{188}$ the actual figure turned out to be roughly one-tenth that amount. ${ }^{189}$ When struggling salmon populations induced the U.S. Army Corps of Engineers to consider breaching four dams on the Lower Snake River, a cost-benefit analysis was commissioned to study the economic and environmental costs and benefits of the proposed breaching. Senator Slade Gorton, likely concerned for his agricultural constituents that depended upon the dams, intervened. The Senator managed to convince the chief of the Corps that the benefits of breaching the dams would be overstated, and that he should overrule the consulting economist, who used a widely-

186. See, e.g., David M. Driesen, The Societal Cost of Environmental Regulation: Beyond Administrative Cost-Benefit Analysis, 24 ECOLOGY L. Q. 545 (1997) (questioning the assumption that cost-benefit criteria has a theoretically coherent and compelling economic rationale); Blais, supra note 114.

187. See Heinzerling, Regulatory Costs, supra note 12; Ackerman \& Heinzerling, supra note 150, Lisa Heinzerling, Five Hundred Life-Saving Interventions and Their Misuse in the Debate Over Regulatory Reform, 13 RiSK: HEALTH, SAFETY \& ENV'T 151 (2002); Lisa Heinzerling \& Frank Ackerman, The Humbugs of the Anti-Regulatory Movement, 87 CORNELL L. REV. 648 (2002).

188. EPA, Progress Report on THE EPA ACID Rain Program 4 (1999), at http://www.epa.gov/airmarkets/ progress/arpreport/acidrainprogress.pdf.

189. The actual compliance cost, calculated ex post, totaled a mere $\$ 726$ million for 1995. Supra note 159. 
accepted economic technique of measuring the value of benefits such as recreation, ecological services, and aesthetic importance. ${ }^{190}$ On the nonenvironmental front, cost estimates of President Bush's recent tax cuts have been widely criticized by many because of the disingenuous assumption that they would expire, rather than be renewed upon expiration, as is more likely..$^{191}$

Nor is the misuse of economics limited to such sophisticated chicanery. Businesses large and small bemoan the costs of federal, state, and local regulation. Yet, a bemoaning of the costs of regulation, even if not intended to mislead, should not be confused with sound economic analysis or any meaningful expression of the concept of efficiency. Sound economic analysis and efficiency-thinking take account of both sides of the ledger, cataloging and measuring as accurately as possible all of the effects of a proposed regulation or policy change. This is not controversial among economists, but the presentation to the lay public of a variety of mistaken or misleading arguments sounding in economics has created an impression that efficiency is as malleable a concept as fairness. It is not. While there may be considerable disagreement over whether an analysis is "complete" or "accurate," economics provides a set of widelyaccepted rules for conducting the analysis. Even if these rules are not always followed perfectly, they provide a method to challenge a finding in a way that may actually be resolved, in a way that fairness arguments cannot.

These rules limit the extent to which manipulation can twist economic analysis. In 1999, the Army Corp of Engineers asked economist Donald Sweeney to perform a cost-benefit analysis on a project to expand a system of dams and locks on the Mississippi River between Minneapolis, Minnesota and Cairo, Illinois. Sweeney's analysis concluded that the $\$ 1$ billion price tag for the project could not possibly be justified by the benefits of alleviating relatively minor delays in barge traffic. The Corps leadership, wishing to please its congressional patrons, attempted to convince Sweeney to alter his analysis. When Sweeney refused, the Corps replaced him with a more pliable panel of economists. Sweeney responded by contacting the Office of Special Counsel, and an embarrassing investigation ensued. The Corps wound up suspending its

190. See Shi-Ling Hsu \& John Loomis, A Defense of Cost-Benefit Analysis for Natural Resource Policy, 32 ENVTL. L. REP. 10,239, 10,240, n.12 (2002).

191. Jackie Calmes, Weekly Report: Red Sunsets, WALL ST. J., May 30, 2003, at A4 (reporting that the business-backed Concord Coalition estimates the actual cost of the President's tax cut to be $\$ 3.3$ trillion through 2013, much more than the President's estimate of $\$ 1.3$ trillion); Editorial, Bush's Budget: Keep Your Eye On Social Security, MINNEAPOLIS STARTRIB., Feb. 6, 2002, at 14A; Editorial, Red Ink: Realistic Look At Federal Spending Shows a Huge Deficit, Buffalo News, July 10, 2003 at B12; Editorial, Bush's Tax Cuts, Cincinnati POST, May 26, 2003 at A10; Editorial, Gimmicks at Center of Tax Cuts, LAS VEGAS SUN, May 30, 2003, at 18. 
own economic work on the project, farming out the analysis to the National Research Council, and implementing reforms to prevent reoccurrences of such interference. ${ }^{192}$ The Corps and EPA have now both implemented whistleblower protections and established outside panel review boards to review commissioned analyses. ${ }^{193}$ The Corps review board reversed Slade Gorton's intervention in the Lower Snake River dam breaching analysis and recommended revisions to the analysis to reflect the ecological and recreational values originally included by Sweeney. ${ }^{194}$

Not all cases will be so clear-cut. The most controversial application of cost-benefit analysis in recent memory pertained to the standard for arsenic under the Safe Drinking Water Act, which was set at ten parts per billion (ppb) in the last days of the Clinton administration. ${ }^{195}$ The costbenefit analysis completed by the EPA found that the benefits of a ten ppb standard ranged from $\$ 140$ to $\$ 198$ million, while the costs were estimated to be $\$ 180$ million or $\$ 206$ million, depending upon whether a discount rate of three percent or seven percent was used. ${ }^{196}$ While the cost estimates slightly exceeded the benefit estimates at the ten ppb level, the EPA justified its decision by noting that the cost-benefit analysis excluded a number of unquantifiable risks, such as non-cancer effects, ${ }^{197}$ and determined that the ten ppb billion level best met the statutory requirement that the standard "maximizes health risk reduction benefits at a cost that is justified by the benefits." 198

The arsenic case presents a problem for advocates of cost-benefit analysis because the benefits and costs of the proposed policy are so close, and the uncertainties so great, that the cost-benefit analysis itself does not tell the policymaker clearly what to do. Sunstein, an advocate of cost-benefit analysis, acknowledges the difficulty of the arsenic case, but argues that it would be the "wrong lesson" to conclude that cost-benefit analysis is utterly useless. ${ }^{199}$ Sunstein argues that the cost-benefit analysis provided important information on what we know and do not know about the appropriate level of regulation of arsenic, and highlighted the

192. Shi-Ling Hsu \& John Loomis, supra note 190.

193. Id.

194. Id.

195. Arsenic and Clarifications to Compliance and New Source Contaminants Monitoring, 66 Fed. Reg. 6,976 (Jan. 22, 2001).

196. See id. at 7010-11.

197. Because of the lack of available data, the cost-benefit analysis considered only the cases of bladder cancer and lung cancer caused by arsenic in drinking water. See id. at 6980 . Various other harmful non-cancer effects were excluded from the analysis, thereby biasing downward the benefit estimates. Id. at 7001 . The study also did not consider other cancers that may be caused by arsenic exposure, such as kidney, liver and colon cancers. $I d$. at 7002.

198. See id.; 42 U.S.C. \& 300g-1(b)(6)(A) (2003).

199. Cass Sunstein, The Arithmetic of Arsenic, 90 GEO. L.J. 2255, 2302 (2002). 
fact that this was a difficult decision. ${ }^{200}$ Professor McGarity takes Sunstein to task for his continued optimism despite the lack of help that costbenefit analysis provided in this case, arguing that cost-benefit analysis is "occasionally comprehensible, but frequently preposterous and always manipulable number spinning." ${ }^{201}$ Heinzerling similarly contends that the uncertainty such as that in the arsenic case "gives agencies plenty of reasons to do the wrong thing." ${ }^{202}$ For example, Heinzerling has long been critical of the way discount rates are misused to render less important the lives that will be lost in the future to latent cancer threats, ${ }^{203}$ and she believes that the arsenic study was similarly flawed. ${ }^{204} \mathrm{I}$ find quite persuasive Heinzerling's argument that cost-benefit analyses tend to fail to account for the "dread" of waiting for cancer to appear. ${ }^{205}$ However, this is quite different from saying that cost-benefit analyses are purposefully manipulated to achieve a particular result.

Moreover, I return to an argument made earlier-that the fact that Heinzerling was able to make her critiques is precisely the point of utilizing cost-benefit analysis and other efficiency-oriented criteria. These criticisms are the product of the transparency that cost-benefit analysis provides. Both sides made numerous criticisms regarding EPA's costbenefit analysis. Some criticized the EPA's assumption that the doseresponse curve for arsenic was linear, arguing that it should be "sublinear," or less risky at low levels. ${ }^{206}$ EPA's response was that using the best available data, which drew upon studies of arsenic responses in Taiwan and Chile, there was no reason to assume that arsenic's doseresponse curve was anything but linear. ${ }^{207}$ Others attacked the use of samples from Taiwan and Chile, countries poorer than the United States with different dietary habits that may create greater susceptibilities to bladder and lung cancer. ${ }^{208}$ EPA defended its decision by noting that the use of human subjects makes the data considerably more reliable than the animal assay studies that have served as the basis for other EPA rulings. ${ }^{209}$ But this conversation is evidence that cost-benefit analysis is not so easily gerrymandered as Heinzerling and McGarity fear.

200. Id.

201. McGarity, supra note 12 , at 2366 .

202. Lisa Heinzerling, Markets for Arsenic, 90 GEO. L.J. 2311, 2338 (2002).

203. Lisa Heinzerling, Discounting Our Future, 34 LAND \& WATER L. REV. 39 (1999); Lisa Heinzerling, The Temporal Dimension in Environmental Law, 31 Envtl. L. Rep. 11055 (2001).

204. Heinzerling, supra note 202, at 2318.

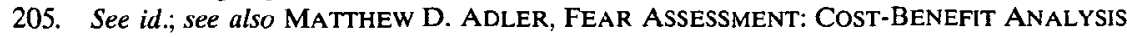
AND THE PRICING OF FEAR AND ANXIETY, at http://papers.ssrn.com/sol3/papers.cfm?abstract_id=466720 (2003).

206. 66 Fed. Reg. at 7003.

207. 66 Fed. Reg. at 7004-05.

208. 66 Fed. Reg. at 7003 .

209. Id. 
Heinzerling also attacks the transparency argument itself. She cites a passage from the EPA's original rulemaking that provided the statutory justification for setting the level at ten $\mathrm{ppb}$, and translates the passage into "plainer English."110 EPA did indeed have a wishy-washy justification for settling on the ten ppb standard, but Heinzerling's point can't be that cost-benefit analysis is to blame for that confusing passage. The rulemaking process has certainly produced an enormous amount of confusion without the aid of cost-benefit analysis. And surely this debate-about the quality of the data and about the appropriateness of assumptions - was more worthwhile than an ultimately unresolvable shoving match between fairness arguments. This discussion was more transparent, in the sense that the EPA was forced to focus on health effects and economic effects and be explicit about them. These health effects and economic effects that are part of the cost-benefit analysis are the same factors that we sit down to think about when we decide what is

210. The original language in the regulation read as follows:

Conclusion. Strict parity of monetized costs and monetized benefits is not required to find that the benefits of a particular MCL option are justified under the statutory provisions of section 1412(b)(6) of SDWA. However, EPA believes that, based on comparisons of cost and benefits (using the various benefit-cost comparison tools discussed), the monetized benefits of a regulatory level of $10 \mathrm{MUg} / \mathrm{L}$ best justify the costs. In addition, as discussed in section III.D. and elsewhere in today's preamble, our further qualitative consideration of the various sources of uncertainty in our understanding of arsenic since the proposal (e.g., such as that surrounding the mode of action), has led us to conclude that our estimate of risk (for the risks we have quantified) is most likely an upper bound of risks and that the higher MCL of 10 $\mathrm{MUg} / \mathrm{L}$ is appropriate. Finally, as discussed in section III.E. of this preamble EPA believes that there are a number of not yet quantified adverse health effects and potentially substantial non-monetized benefits at $10 \mathrm{MUg} / \mathrm{L}$ that increase the overall benefits at this level. In summary, based on our reanalysis of costs, benefits, and health risk reduction, and factoring in the uncertainties in these analyses and the degree and nature of risk, EPA believes the final $\mathrm{MCL}$ of $10 \mathrm{MUg} / \mathrm{L}$ represents the level that best maximizes health risk reduction benefits at a cost that is justified by the benefits and that the other regulatory options considered in the proposed rule do not satisfy the statutory requirements of section 1412(b)(6) of SDWA. We are therefore exercising our discretionary authority under the statute to establish an MCL at a level higher than the feasible level and setting that level at $10 \mathrm{MUg} / \mathrm{L}$.

66 Fed. Reg. at 7022-23. Heinzerling translates this into the following:

it seems fair to say that the EPA chose the standard of $10 \mathrm{ppb}$ because: (1) the quantified costs of this standard were lower than the costs of stricter standards; (2) the quantified benefits of this standard were lower than the benefits of stricter standards, but not as much lower as the costs of stricter standards were higher; (3) the individual risk allowed by the new standard was acceptable, and it was at once important to the decision yet not considered by the agency; (4) the quantified benefits stated in terms of lives saved were not likely to be higher than the agency had estimated; (5) the existence of unquantified benefits from regulating arsenic in drinking water may have meant that the agency's quantified estimate of benefits was too low; and (6) the agency was meeting statutory requirements in setting the standard.

Heinzerling, supra note 202, at 2337. 
fair. Cost-benefit analysis simply requires that we explain how they factor in.

At bottom, detractors of cost-benefit analysis may be disturbed by an elitist notion that agency decision-making will become less transparent and less accountable to the general public if cost-benefit analysis is used, all because of a "contempt" that technocratic elitists have for the way that the "simple-minded" public" ${ }^{211}$ makes choices about risk. People do indeed make poor choices with respect to risk. But in an informationoverloaded world, that does not make the general populace simpleminded. Rather, poor choices stem from a market failure in information about risk. ${ }^{212}$ The market failure exists because special interest groups have been repeatedly able to exploit the lack of accurate and complete risk information to their advantage. Cost-benefit analysis, and more generally efficiency-thinking, provides a forum and a set of rules under which a more open competition of information can be waged. It is true that information will continue to be manipulated, with or without costbenefit analysis. But as long as we can agree to a set of rules under which this war is waged, there is hope that environmental policy analysis will not be a futile exercise.

Responding to critics of the practice of consulting legislative history in interpreting statutes, Justice Breyer has argued that its occasional unhelpfulness is not an argument for abandonment of the practice. ${ }^{213} \mathrm{We}$ should adopt a similar attitude towards cost-benefit analysis and efficiency considerations in environmental law. Like legislative history, it will not always be controlling, but it is folly to make a point of ignoring or avoiding it. One need not believe that cost-benefit analysis is a panacea; it is enough to believe that it can at times do better than the alternatives, and that it can play an important role in decisionmaking and standard setting.

211. McGarity, supra note 12, at 2341.

212. See, e.g., Daniel Kahneman \& Amos Tversky, Prospect Theory: An Analysis of Decision Under Risk, 47 ECONOMETRICA 263 (1979); Richard H. Thaler, et al., The Effect of Myopia and Loss Aversion On Risk-taking: An Experimental Test, 112 Q. J. ECONOMICs 647 (1997); Amos Tversky, et al., The Causes of Preference Reversal, 80 AM. ECON. REV. 204, 211 (1990); Paul Slovic, et al., Preference for Insuring Against Probable Small Losses: Insurance Implications, 44 J. RISK \& INSURANCE 237 (1977).

213. Stephen G. Breyer, On the Uses of Legislative History in Interpreting Statutes, 65 S. CAL. L. REV. 845, 861-62 (1992). 


\section{Efficiency Can Better Protect The Public Interest}

The public interest ${ }^{214}$ in environmental law typically involves a relatively small gain (in environmental economic terms, a small increment in wealth) for a large number of people (the general public, often including those not yet born). By contrast, private interests in environmental law are typically small and intensely concentrated. Where an industry is fairly large, such as the electricity generating industry or the hardrock mining industry, the resistance to unfavorable changes in regulation is intense. The intensity of the interest makes up for the disadvantage of being a minority interest, as the members of the organization in effect become single-issue voters.

The effect of emphasizing efficiency and wealth maximization in environmental law would generally be to favor policies that slightly increase the wealth of many persons over policies that greatly increase the wealth of a few persons, provided the sum of the former is greater than the sum of the latter. ${ }^{215}$ Taking efficiency into account would tend to highlight policies that have gains (economic or environmental) that inure to a large number of people, present and future, even if the gain for each individual is small. Policies that have high costs but even higher gains would tend to be foiled in a fairness-oriented system, because of the difficulty of imposing the costs on the losing stakeholders. Under an efficiency-oriented system, such policies might have a better chance. In this sense, efficiency can provide the necessary political cover for politicians to not only represent their constituents, but the public interest as well.

Of course, economic analysis has overlooked some interests and interest groups in the past, and will no doubt continue to do so. However, our current fairness orientation in environmental law has worked systematically to undermine the public interest. Some on the environmental side have been complicit in this subversion. Unwilling to accept monetization of the public interest, the environmental side is stuck

214. While most of us have a sense of the meaning of "public interest," the term may be used too cavalierly. James Huffman has been critical of environmental organizations for pursuing essentially self-interested goals while "assum[ing] the comfortable mantle of public interest." James L. Huffman, The Public Interest in Private Property Rights, 50 OKLA. L. REV. 377,378 (1997).

215. If one were to adopt a utilitarian notion of efficiency, as opposed to a wealth maximization notion, it is conceivable that a regulation unfavorable to an industry in terms of economic losses, but favorable to a broader public in terms of environmental gains, would not be efficient after all. It could be that the loss in utility of the losers is so severe that the winners could not compensate them. It is thus possible that a wealth maximizing policy move would not be Kaldor-Hicks efficient. 
arguing that it has a "right"216 to: a well-maintained and ecologically healthy network of public lands; the protection of species from extinction; cleanup of hazardous wastes by those involved with the production of the hazardous waste; a world free of harmful air and water pollutants. In effect, the environmental side continues to argue that it has a "property rule" entitlement rather than a "liability rule" entitlement. ${ }^{217}$ In truth, if one takes an honest look at how much progress we have made on environmental law and policy in the past decade, it becomes clear that the environmental side has only a weak entitlement.

\section{E. Efficiency Can Produce a More Dynamic Economy}

Properly-designed efficiency-oriented environmental regulation will create conditions more conducive to innovation both in terms of environmental protection and compliance cost savings. While detractors of efficiency-based environmental regulation may be willing to concede the latter, they have generally not accepted the former, and still subscribe to the notion that there is a tension between environmental protection and economic health. This comes from adopting too narrow a view of economic health, a charge that can be leveled at many economists as well. Properly framed, environmental health is one vitally important aspect of economic health. Environmental health helps maintain human health and productivity, physically and spiritually, and insures the continued production of ecosystem services necessary for civilization: cleanliness and abundance of air, water, food, and medicinal resources.

Efficiency-oriented regulation can reduce the cost of ensuring environmental health, in addition to determining how much of it is desirable. More importantly, efficiency-oriented regulation can redirect entrepreneurial energies towards finding ways of reducing pollution more cheaply and effectively, rather than ways of complying with complicated and heavily rules-based regimes. By "a more dynamic economy," I thus mean one in which the compliance and transaction costs of environmental protection are minimized, leaving more resources available for more productive tasks, some of which can be devoted to more environmental protection.

216. This seems to be the tack taken in, for example, Frank Ackerman \& Lisa Heinzerling, Pricing the Priceless: Cost-Benefit Analysis of Environmental Protection, 150 U. PENN. L. REV. 1553,1564 (2002) (arguing that we "cannot buy the right to kill someone for $\$ 6.3$ million.").

217. A "liability rule" is one in which a party with an entitlement can be deprived of the entitlement if a payment is made; a "property rule" is one in which consent of a party with an entitlement must be obtained as a condition to transfer of the entitlement. Guido Calabresi \& A. Douglas Melamed, Property Rules, Liability Rules, and Inalienability: One View of the Cathedral, 85 HARV. L. REV. 1089 (1972). 


\section{FAIRNESS VERSUS EFFICIENCY IN PRACTICE}

The discussion up to this point has been of a philosophical nature in that the debate has been shaped both by attitudes towards the environment and economics and by general views on utilitarianism. The actual implementation of efficiency-oriented programs, however, not only has laid bare philosophical differences between advocates and detractors of efficiency-oriented regulation, but also has revealed an entirely new set of implementation issues to argue about. These issues would benefit from discussion of a more empirical nature, since fairness advocates and efficiency advocates are likely to agree on a wide range of desirable and undesirable effects of fairness-based and efficiency-based regulation. Toward this end, I examine some specific programs that I identify as fairness-based and efficiency-based and discuss the positive and negative results that have accrued from these programs.

\section{A. Fairness-based Programs}

While efficiency-thinking has crept into environmental law in some areas, the general structure of environmental law has remained one that is oriented toward fairness. As between the three versions of fairness described in the first section-distributive, expectations, and retributive-the distributive and expectations versions have been particularly influential and prevalent. Occasionally, a retributive sense of fairness expresses itself as an environmental organization seeking to impose some financial cost upon polluters, even if doing so will produce no environmental benefits, and possibly even a net harm to the environment. ${ }^{218}$ But by and large, fairness has manifested itself in the form of statutory and regulatory structures that are distributively fair (that attempt to equalize burdens and benefits) or are fair in the expectations sense (that avoid ex post regulation). As lawyers, our instinct to think in fairness terms is so ingrained that most proposed solutions to environmental problems are subconsciously fairnessoriented. ${ }^{219}$

\section{New Source Review And Grandfathering Under The Clean Air Act}

One of the most prominent manifestations of the expectations version of fairness involves the differential treatment of new sources and existing sources of pollution. Construction of new stationary sources of

218. See infra text accompanying note 404 (discussing Greenpeace's opposition to Individual Transferable Quotas).

219. Interestingly, Driesen has the contrary view that "[i]n the environmental area, efficiency-based analysis has dominated," and that "[m]ost legal scholars have assimilated [economics] almost unconsciously." DRIESEN, supra note 12, at 2-3. 
air pollution in "non-attainment" areas-areas that have persistent problems with certain air pollutants ${ }^{220}$-must achieve the Lowest Achievable Emissions Rate (LAER), meaning that new sources must have an emissions rate as low as any achieved by any facility in the same or similar industry. ${ }^{221}$ By contrast, existing sources in such areas must comply with the considerably less onerous Reasonably Available Control Technology (RACT) standard. ${ }^{222}$ In "attainment" areas-areas that do not have the persistent air pollution problems that non-attainment areas do-new sources must install Best Available Control Technology ${ }^{223}$ (BACT) - a standard somewhere in between the first two in terms of stringency - while existing sources in such areas need not undertake any new pollution reduction measures at all. The LAER standard and the BACT standard constitute the "New Source Review" program that subjects new stationary sources of pollution to more stringent emissions control requirements than existing sources. Similarly, the Clean Water Act provides for more stringent performance standards for new sources of water pollution, standards that are achievable using "best available demonstrated control technology."224 The fact that existing facilitics are grandfathered into weaker standards is clearly a reflection of our reluctance to impose stringent new regulations on existing sources. ${ }^{225}$ The rationale behind this reluctance is clearly an expectations sense of fairness, and something of an "expectations" theory of property: retroactive regulation on such expensive capital investments is something that would frustrate the reasonable expectations of the owner. ${ }^{226}$

220. Non-attainment status is defined with respect to attainment of standards established for the permissible concentrations of "criteria" air pollutants, pollutants determined by the EPA to be of special health concern. Clean Air Act $\$ 108(a)(1), 42$ U.S.C. $\$ 7408(a)(1)(2003)$.

221. See id \$173(a)(2)/

222. Id. $\$ 172(\mathrm{c})(1)$. This differential treatment is a form of grandfathering that is "fair" in a narrow sense-to those with existing pollution sources - but is unfair to those who may wish to construct new plants in the future.

223. Id. § $165(\mathrm{a})(4)$.

224. Id. $\$ 306(\mathrm{a})(1)$.

225. Heidi Gorovitz Robertson, If Your Grandfather Could Pollute, So Can You: Environmental "Grandfather Clauses" and Their Role in Environmental Inequity, 45 CATH. U.L. REV. 131, 160-63 (1995); see also H.R. REP. No. 95-294 (1977) ("[T]o prevent disruption of present or planned sources, the committee has authorized extensive 'grandfathering' of both existing and planned sources.").

226. The expectations theory of property is developed in Craig Anthony Arnold, The Reconstitution of Property: Property as a Web of Interests, 26 HARV. ENVTL. L. REV. 281, 327-31 (2002). According to Arnold, the origin of the expectations theory of property can be traced all the way back to Bentham, but its modern-day applications have been drawn from Frank I. Michelman. See Michelman, supra note 182. For analyses of the influence of this theory on takings jurisprudence, see Daniel Mandelker, Investment-Backed Expectations in Takings Law, 27 URB. LAW. 215 (1995), and Eagle, supra note 181. 


\section{Emissions Rate Standards Under The Clean Air Act}

The Clean Air Act also imposes different emissions standards for different types of coal-fired power plants. Under Title IV of the Clean Air Act, ${ }^{227}$ standards for emissions of oxides of nitrogen (NOx), a criteria air pollutant, depend upon the coal combustion technology used:

From 1995 to 2000 , the permissible emissions rate of NOx for tangentially-fired boilers was $0.45 \mathrm{lb} / \mathrm{mmBTU}^{228}$ (mmBTU is millions of British Thermal Units, a measure of the heat content of the coal being burned). After 2000, the rate dropped down to 0.40 $\mathrm{lb} / \mathrm{mmBTU}^{229}$

From 1995 to 2000 , the permissible emissions rate of NOx for dry bottom wall-fired boilers was $0.50 \mathrm{lb} / \mathrm{mmBTU}$. After 2000 , the rate dropped down to $0.46 \mathrm{lb} / \mathrm{mmBTU}^{230}$

After 2000 , the permissible emissions rate of NOx for wet bottom boilers was $0.84 \mathrm{lb} / \mathrm{mmBTU}$. $^{231}$

After 2000, the permissible emissions rate of NOx for cyclone boilers was $0.86 \mathrm{lb} / \mathrm{mmBTU} .^{232}$

227. Other provisions of the Clean Air Act affect NOx emissions. A twelve-state interstate agency mandated by section 184 of the Clean Air Act, the Ozone Transport Commission, has established an emissions trading system for emissions of NOx. See infra text accompanying notes 325-326. Also, the Clean Air Act requires EPA to require [SH-requires the EPA to require? Is there another word you could use here...mandate?- EICl states to revise their State Implementation Plans to reduce criteria-air pollutants if the existing plans are inadequate for achieving the required reduction of pollution. [ $\mathrm{SH}$ - deletion suggested to reduce words in a long and complex sentence - EIC]Clean Air Act $\S 110(\mathrm{k})(5), 42$ U.S.C. $\$ 7410(\mathrm{k})(5)$ (2003). In 1998, the EPA issued the NOx SIP call, a call to twenty-two states to revise and resubmit State Implementation Plans that would do a better job of reducing emissions of NOx. Finding of Significant Contribution and Rulemaking for Certain States in the Ozone Transport Assessment Group Region for Purposes of Reducing Regional Transport of Ozone, 63 Fed. Reg. 57,356 (Oct. 27, 1998). For a general discussion of the NOx SIP Call and the problem of interstate transport of air pollution, see Arnold W. Reitze, State and Federal Command-and-Control Regulation of Emissions from Fossil-Fuel Electric Power Generating Plants, 32 ENVTL. L. 369, 412-16 (2002), and Craig N. Oren, Clean Air and Interstate Transport: Seeing the Big Picture, 10 N.Y.U. ENVTL. L.J. 196 (2002). Finally, EPA considered requiring states to revise their State Implementation Plans under section 126 of the Clean Air Act, which requires EPA to address pollution problems of an interstate nature. See Kate M. Joyce, Who'll Stop the Rain? 7 ALBANY L. ENVTL. OUtLooK J. 94, 121-22 (2002). Both the NOx SIP Call and the section 126 requirements will include NOx emissions trading. See EPA, OVERVIEW OF NOX TRADING PROGRAMS, at http://www.epa.gov/airmarkets/progsregs/noxview.html (last updated Oct. 29, 2002). More recently, EPA has proposed incorporating such NOx emissions requirements under the NOx SIP Call, harmonizing NOx emissions reductions requirements. Air Quality Standards: EPA Proposes to Streamline Requirements for Cutting NOx Emissions in Eastern States, 32 ENV'T REP. 799, Apr. 11, 2003.

228. 40 C.F.R. \& 76.5 (1997).

229. Id. \& 76.7 .

230. Id. $\S \S 76.5,76.7$.

231. Id. $\$ 76.6$.

232. Id. 
After 2000, the permissible emissions rate of NOx for boilers using cell burner technology was $0.68 \mathrm{lb} / \mathrm{mmBTU}^{233}$

After 2000 , the permissible emissions rate of NOx for vertically-fired boilers was $0.80 \mathrm{lb} / \mathrm{mmBTU}^{234}$

Why such detailed differentiation among different types of coal-fired power plants? This schedule was established so that all coal-fired power plants could comply with the regulation by installing the same end-ofpipe technology. ${ }^{235}$ In effect, all coal-fired power plants were expected to do the best with what they had. The fact that different coal-fired power plants could emit NOx at different rates, but spend roughly the same amount of effort reducing NOx emissions is clearly a fairness-driven mode of regulation. In my parlance, this is a distributive sense of fairness, requiring from everyone equal efforts, regardless of effectuality. It was important that no particular type of coal-fired boiler should be disadvantaged by being required to undertake more expensive retrofits than others.

\section{Nationally Uniform Effluent Standards Under The Clean Water Act}

Section 301 of the Clean Water Act mandates the promulgation of nationally uniform effluent limitations for point source water polluters. ${ }^{236}$ Effluent limitations are technology-based, and are specific to every type of point source polluter. ${ }^{237}$ So, all pulp and paper mills, whether they are located in Maine or Oregon, face the same burden in cleaning up the nation's waters. An important reason for establishing uniform technology-based effluent limitations was to solve enforcement problems that had earlier plagued the Federal Water Pollution Control Act. ${ }^{238}$ Yet

233. Id.

234. Id.

235. Senator Trent Lott inserted this complex rate standard schedule who explained that under this amendment, "utilities will not be forced to install unreasonably expensive equipment [and].. .the application of low-NOx burner technology, a much more reasonable and costeffective method proven to successfully achieve significant NOx reductions" will provide the basis for NOx emission limits. Byron Swift, How Environmental Laws Work: An Analysis of the Utility Sector's Response to Regulation of Nitrogen Oxides and Sulfur Dioxide Under the Clean Air Act, 14 TULANE ENVTL. L.J. 309, 355-56, n.231 (2001). Sidney Shapiro and Tom McGarity have also made this fairness argument. They argue that technology-based approaches that tell polluters to "do the best they can" in reducing pollution and health risk may lead polluters to "justifiably decide to reduce risky behavior beyond the point indicated by a cost-benefit test." Shapiro \& McGarity, supra note 173, at 744; see also Thomas O. McGarity \& Sidney A. Shapiro, OSHA's Critics and Regulatory Reform, 31 WAKE FOREST L. REV. 587, 631-32 (1996).

236. See 33 U.S.C. § 1311(b) (2004); see also Richard B. Stewart, A New Generation of Environmental Regulation? 29 CAP. UNIV. L. REV. 21, 57-58 (2001).

237. See 33 U.S.C. \& 1311(b) (requiring the establishment of effluent limitations for "categories and classes of point sources").

238. See William J. Andreen, The Evolution of Water Pollution Control in the United States-State, Local and Federal Efforts, 1789-1972: Part II, 22 STAN. ENVTL. L.J. 215, 270 (2003). 
Congress was clearly very concerned with achieving uniformity in abatement technology for equality's sake, and with preventing industries from migrating to places with less stringent standards. ${ }^{239}$ Location-specific environmental impacts were ignored, ${ }^{240}$ even as testimony emphasized the differing circumstances that might call for differing levels of stringency. ${ }^{241}$

At the same time, these pulp and paper mills face discharge standards different from those imposed upon other facilities that discharge the same pollutants, in the same place. ${ }^{242}$ Facility type-specific effluent discharge standards create situations in which, for example, a pulp and paper mill on the banks of the Willamette River in Oregon discharging dioxin would face the same dioxin discharge regulation as a pulp and paper mill on the banks of the Penobscot River in Maine, but would face a different discharge regulation from a dioxin-discharging chemical manufacturer just upriver on the Willamette..$^{243}$

This scheme seems fair in the distributive sense, in that effluent discharge standards could be tailored to specific polluting technologies and could be calibrated so that the economic burden is roughly equal across different industries. The desire to regulate by normalizing effort across industries is palpable, as the standards are based upon the "best available technology economically achievable," 244 or the "best

239. See 117 CONG. REC. 38,797, 38,861 (1971) (statement of Sen. Muskie) ("[U]nless there is uniformity of regulation, polluters will seek to escape stringent requirements of one area, and they will go to other areas where there are less stringent requirements.").

240. See S. REP. No. 92.1236, at 126 (1972) (emphasis added):

Except as provided in section 301(c) of this Act, the intent of the Conferees is that effluent limitations applicable to individual point sources within a given category or class be as uniform as possible. The Administrator is expected to be as precise in his guidelines ... so as to assure that similar point sources with similar characteristics, regardless of their location or the nature of the water into which the discharge is made, will meet similar effluent limitations.

241. See CWA Legislative History, supra note 102, at 202 (testimony of Russell E. Train, Chairman, Council on Environmental Quality):

The across-the-board treatment approach has been advanced on the grounds that water-quality objectives often cannot be translated into individual effluent limitations. Accordingly, it is argued that such limitations should be based upon elimination of all discharges of across the board use of the best available control technology. I do not agree with this conclusion for a number of reasons. In cases where efforts have been made to relate effluent limitations to water-quality objectives, ... the results have been sufficiently promising to indicate that we are pursuing the correct course.

242. CWA Legislative History, supra note 102 , at 169 . ("It is the intention that ... the Administrator will interpret the term 'best practicable' when applied to various categories of industries as a basis for specifying clear and precise effluent limitations.").

243. There is some flexibility built into Clean Water Act. Point source dischargers may apply for variances on the grounds that they are "fundamentally different" from the class of polluters in which they are grouped. Federal Water Pollution Control Act, $\S 301(n), 33$ U.S.C. $\S$ 1311(n) (2004). Point source discharge limits may also be modified if the prescribed discharges would "interfere with the attainment or maintenance of ... water quality." $\S 302(a)$.

244. This standard applies to sources discharging toxic or non-conventional pollutants. $\S$ 301(b)(2)(A). 
conventional pollutant control technology, ${ }^{245}$ which are established by considering the capacity of plants to abate pollution. ${ }^{246}$

\section{Greenhouse Gas Emissions Under The Kyoto Protocol}

Perhaps the most important manifestation of fairness has played itself out in the international environmental law arena. The first international attempt to implement the 1992 Framework Convention on Global Climate Change, ${ }^{247}$ the Kyoto Protocol, ${ }^{248}$ calls for the group of developed countries, or the "Annex I" nations, to reduce greenhouse gas emissions reductions which are believed to be leading to global climate change. The parties to the Kyoto Protocol negotiated an agreement that required the reduction of emissions only from Annex I nations, but required nothing of developing countries. ${ }^{249}$

The argument put forth by developing countries for their exemption from Kyoto requirements is that the greenhouse gas emissions problem was created by the developed countries. A strong retributive sense of fairness dictates that the developed countries at least take the initial steps toward addressing the greenhouse gas problem. ${ }^{250}$ The Annex I nations,

245. This standard applies to sources of conventional pollutants. $\S 301(\mathrm{~b})(2)(\mathrm{E})$.

246. CWA Legislative History, supra note 102, at 1222.

The factors relating to the assessment of the best available technology shall take into account the age of equipment and facilities involved, the process employed, the engineering aspects of the application of various types of control techniques, process changes, the cost of achieving such effluent reduction, and other factors as the Administrator deems appropriate.

(statement of Mr. Grover).

247. United Nations Framework Convention on Global Climate Change, May 9, 1992, 31 I.L.M. 849.

248. Kyoto Protocol to the United Nations Framework Convention on Climate Change, Dec. 10, 1997, 37 I.L.M. 22 (1998).

249. See id. at Annex B.

250. United Nations Framework Convention on Global Climate Change Report of the Conference of the Parties on its Third Session, Dec. 1-11, 1997, at 5, available at http:/unfccc.int/resource/docs/cop3/07.pdf (statement by the President of the Conference at its second session):

It was the responsibility of the industrialized nations that had indirectly placed burdens on the rest of the world to take the lead in meeting existing commitments, in reducing emissions and in alleviating human suffering caused by climate change.... In the interests of equity, binding commitments for non-Annex I Parties could not even be envisaged until agreement had been reached on a fair system of apportionment of emission limits, a globally agreed reduction pathway and a projected sustainable future emission level on an equitable basis, and until there was reliable and predictable financial provision for the acquisition and adaptation of sound technologies, know-how and production systems in developing countries.

The preamble to the Framework Convention on Climate Change includes the following language:

Noting that the largest share of historical and current global emissions of greenhouse gases has originated in developed countries, that per capita emissions in developing 
however, were concerned about projections of greenhouse gas emissions that indicated rapid growth of emissions from developing countries. ${ }^{251}$ Exempting developing countries from any restrictions at all, it was feared, could undermine the emissions reductions achieved by the Annex I nations. ${ }^{252}$

The fairness argument, however, prevailed, and developing countries were excused from any obligations under the Kyoto Protocol. It is still unclear as to whether the required supermajority of the Annex I countries (notably excluding the largest emitter, the United States ${ }^{253}$ ) will ratify the Kyoto Protocol, agreeing to the mandated percentage emissions reductions. ${ }^{254}$

\section{B. Efficiency-based Programs}

By "efficiency-based" regulatory programs, I mean programs that are designed in such a way as to achieve efficiency gains from trading rights. Under these programs, rights must be defined in a way that permits greater flexibility for the regulated party. In a Hohfeldian sense, ${ }^{255}$ the regulator seeks to endow a regulated party with a more complete property right by adding a right of alienability to the regulated party's "bundle" of rights. Fundamentally, efficiency-based programs encourage trading to accomplish two objectives: (i) reduce compliance costs by giving the regulated party greater flexibility in achieving what is

countries are still relatively low and that the share of global emissions originating from developing countries will grow to meet their social and developing needs ....

United Nations Framework Convention on Climate Change (1992), at http://unfccc.int/resource/docs/

convkp/conveng.pdf.

251. See William D. NORDHAUS \& JOSEPH BOYER, WARMING THE WORLD: ECONOMICS MODELS OF GLOBAL WARMING 8-8 to 8-10, at http://www.econ.yale.edu/ nordhaus/homepage/ web\%20table\%20of\%20contents\%20102599.htm (1999).

252. Economic logic indicates that as Annex I nations seek to reduce greenhouse gas emissions by reducing the use of fossil fuels, fossil fuel prices will drop. Developing countries could take advantage of the lower fossil fuels prices and undo the good done by Annex I countries by consuming more fossil fuels. SCOTT BARRETT, ENVIRONMENT AND STATECRAFT 383 (2003).

253. The United States emitted 6.568 billion metric tons of carbon equivalent in 2001, nearly twice that emitted by the world's second-largest emitter. U.S. Leads World in Carbon Emissions From Fossil Fuels, Followed by China, Russia, ENV'T REP., Mar. 28, 2003, at 687.

254. As matters currently stand, the anticipated ratification by Russia would bring the Kyoto Protocol into effect. The treaty requires the ratification of nations representing $55 \%$ of the world's greenhouse gas emissions, and the total share of countries currently that have ratified the treaty stands at $43.9 \%$. Russia's share is $17.4 \%$, so its ratification would bring the treaty into binding effect on the signatory nations. Joe Kirwin, Moscow Yet to Set Time Frame for Ratifying Kyoto Pact; EU Representatives Disappointed, 26 INT'L ENV'T, Mar. 12, 2003, at 261-62.

255. The rights as a bundle of sticks concept is attributed to Hohfeld, although Hohfeld was cognizant of the problems that would result from overuse of this conception. See Wesley Newcomb Hohfeld, Some Fundamental Legal Conceptions as Applied in Judicial Reasoning, 23 YALE L.J. 16 (1913). 
considered compliance, and (ii) align the regulated party's incentives with societal objectives of greater environmental protection. ${ }^{256}$ As discussed below, such programs do not necessarily achieve these objectives. But the goal is to engineer efficiency gains in a polluting sector without creating disturbances outside the sector.

Because an efficiency orientation has not traditionally been influential in the development of environmental law, efficiency-based programs are relatively few. I classify them into two types: decentralized trading programs and regulatory bargaining programs.

\section{Decentralized Trading Programs}

Decentralized trading programs currently in effect include emissions trading programs for air pollution, individual transferable quota programs for fishing, and transferable development rights programs for land development. These programs typically involve a governmentallyimposed limit, or "cap," on a polluting activity, and the freedom to trade rights to engage in the polluting activity. The programs are decentralized in the sense that the regulatory authority imposes few restrictions on the trading of rights. Once the overall limit is determined and rules established, the transaction costs due to governmental interference are minimized.

By far the best known emissions trading program arises under Title IV of the 1990 Clean Air Act Amendments, which implemented an emissions cap and allowance trading program for emissions of sulfur dioxide $\left(\mathrm{SO}_{2}\right)$. Under the program (the $\mathrm{SO}_{2}$ emissions trading program), total nationwide emissions of $\mathrm{SO}_{2}$ emitted from power plants were capped, and allowances to emit that sum total were distributed among the largest and dirtiest power plants. Each allowance entitles the holder to emit one ton of $\mathrm{SO}_{2}$ and can be used to emit, banked for future use, or sold to a willing buyer. The EPA, which administers the program, imposes very few restrictions upon trading. ${ }^{257}$ Enforcement is accomplished by a requirement that continuous emissions monitors be installed in all smokestacks to record and report the quantity of $\mathrm{SO}_{2}$ actually emitted. ${ }^{258}$ Penalties for exceeding the amount of emissions are quite severe $-\$ 2,000$ per excess ton ${ }^{259}$ - when compared with prices for allowances themselves, which have ranged between a low of $\$ 65$ per ton in $1996^{260}$ to a high of $\$ 326$ in $1992 .{ }^{261}$ This differential has enabled firms

256. Critics of efficiency-based programs often argue that efficiency-based programs do too much of the former and too little of the latter.

257. Swift, supra note 235, at 401.

258. See Clean Air Act $\S 412$ (a), 42 U.S.C. $\$ 7651 k(a)$ (2003).

259. Id. $\$ 7651 \mathrm{j}(\mathrm{a})$.

260. ELLERMAN, supra note 159, at 172-73 (1995 dollars). 
to buy a margin of error in order to avoid a costly penalty. Other emissions trading programs are in place, most of them modeled after the $\mathrm{SO}_{2}$ emissions trading program. ${ }^{262}$

A decentralized trading concept has also been applied to the problem of overfishing. Some chronically overharvested fisheries have been subjected to regulation under individual transferable quota programs (ITQ programs), which entitle quota holders to catch a specific amount of fish per season. ${ }^{263}$ As opposed to emissions trading programs, the cap on total fishing permitted is usually not static, but is typically administratively determined every year as a "total allowable catch." 264 The individual fishing rights under ITQ programs are typically expressed as a percentage of the total allowable catch. As with emissions trading, ITQ programs impose few restrictions on trading, although fears of overconcentrating quota shares and market power have led to limits in most ITQ programs on how much quota any individual entity or its affiliates can hold. ${ }^{265}$

A third similar program contemplates a cap on the amount of land development allowed, and allows the transfer of development rights (TDR). As in emissions trading and ITQ programs, some overall cap on development in a defined area is imposed, and rights to develop are allocated on the basis of land ownership. ${ }^{266}$ Unlike most ITQ programs and emissions trading programs, TDR programs often impose restrictions as to where development rights can be exercised. ${ }^{267}$ Land parcels of greater environmental sensitivity, requiring more stringent restrictions on development, may not be eligible for development, regardless of the number of TDRs possessed by the owner of the parcel. ${ }^{268}$

Fundamentally, each of these programs involves the governmental establishment of a broad environmental goal, and allows regulated parties to trade pollution rights with each other. In effect, the regulated

261. Id. at 174 (1995 dollars).

262. See supra note 227.

263. SuZANNE IUdicello, ET AL., Fish, MARKETS, AND FISHERMEN: THE ECONOMICS OF OVERFISHING 82-84 (1999).

264. See id. An exception was an early ITQ program in New Zealand, which issued ITQs expressed in fixed weights, rather than a share of total allowable catch. The drawbacks of this program became apparent when new biological information indicated that the total allowable catch was too high, and needed to be reduced significantly. The New Zealand government had to spend NZ $\$ 45$ million buy back ITQs. New Zealand subsequently changed its ITQs so that ITQs represented shares of total allowable catch, rather than fixed weights, relieving it of the financial burden of reducing total allowable catch. Id. at 101-03.

265. See id. at 104, 140.

266. JULIAN CONRAD JUERGENSMEYER \& THOMAS E. ROBERTS, LAND USE PLANNING AND CONTROL LAW 409 (1998) (explaining how development rights are "severed" from the land itself).

267. Id. at $409-10$.

268. Id. 
parties are given a great deal of freedom in determining, as a group, how the burden of meeting the goal will be met and by whom. These programs seek to tap into the potential for gains from trading among regulated entities. If marginal compliance costs differ among regulated entities, a decentralized trading scheme will realize savings in overall compliance costs, as allowances flow to those that value them most.

\section{Regulatory Bargaining Programs}

Regulatory bargaining programs seek a very different type of efficiency. In contrast to decentralized trading programs, regulatory bargaining programs involve a regulatory authority as a trading partner with regulated entities. These programs seek to realize gains from trading rights that may be of more value to the regulator than to the regulated entity, and vice versa. An ideal regulatory bargain will involve the trade of land that is of little development value but of great ecological value, in exchange for land that is of great development value but little ecological value. Each side gives up something of little value to itself but of great value to the other. Examples of regulatory bargaining programs include Wetlands Mitigation Banking under the Clean Water Act, Habitat Conservation Planning under the Endangered Species Act, and Project $\mathrm{XL}$, an EPA initiative to engage in site-specific relaxations of otherwise applicable regulatory requirements.

Wetlands Mitigation Banking arises under section 404 of the Clean Water Act, which requires a permit from the U.S. Army Corps of Engineers (the "Corps") for the "dredging and filling" of wetlands under federal jurisdiction. A dredge and fill permit may be issued if the Corps determines that there is no "practicable alternative." 269 If a permit is issued, impacts to wetlands are to be avoided. If impacts can not be avoided, then they are to be minimized. Finally, if impacts cannot be minimized, then they must be mitigated. ${ }^{270}$ Most permit application reviews now skip down to the third stage, determining measures for the mitigation of impacts (typically the destruction of wetlands). ${ }^{271}$ Mitigation can be accomplished by creating a new wetland, restoring a degraded one, or some other action that has the effect of improving wetland health somewhere, somehow. ${ }^{272}$ Ideally, a trade involves the loss of an ecologically insignificant but economically valuable wetland for the

269. 40 C.F.R. $\$ 230.10$ (a) (2002).

270. Memorandums of Agreement between the U.S. Environmental Protection Agency and U.S. Department of Defense, 55 Fed. Reg. 9210, 9211-12 (Mar. 12, 1990) (concerning the determination of mitigation under the Clean Water Act section 404(b)(1) guidelines).

271. Royal C. Gardner, Banking on Entrepreneurs: Wetlands, Mitigation Banking, and Takings, 81 IOWA L. REV. 527, 536-37 (1996).

272. Id. 
restoration or creation of an ecologically valuable wetland that has little development value. The end result, in theory, is that the developer benefits by gaining a valuable economic right to develop, and the Corps achieves a net ecological gain because the developer delivers a more ecologically valuable wetland than was lost to development.

Habitat Conservation Planning under the Endangered Species Act ("ESA") allows landowners subject to ESA-required land use restrictions to obtain some qualified immunity from prosecution under the ESA. In exchange for an incidental take permit ${ }^{273}$ to essentially violate the ESA by engaging in the "take" of species protected by the ESA, a landowner must agree to undertake mitigation measures that are deemed to compensate for the harm to the protected species. The landowner must submit her plan in the form of a Habitat Conservation Plan, which outlines the actions that the landowner intends to take that may result in the otherwise prohibited "take" of the species, and which sets forth the mitigation measures. ${ }^{274}$ Mitigation measures described in Habitat Conservation Plans have included the enhancement of onsite or offsite habitat, the acquisition of offsite property as substitute habitat, and the simple payment of money. ${ }^{275}$ The Habitat Conservation Planning program is an efficiency-driven regulatory program because it seeks to create trading opportunities such that regulated landowners are relieved of some of the costs of protecting endangered species, but will compensate by finding economically inexpensive ways to help endangered species. For example, landowners may exploit their own land in a way that would violate the ESA if they also acquire property to help create better and less fragmented habitat for wildlife management. The principle behind Habitat Conservation Plans is the same as for Wetland Mitigation - a trade is made so that endangered species have better and more habitat, and the developer gains a valuable development right that she might not otherwise have under the ESA.

Finally, Project XL was a Clinton administration initiative to grant case-by-case waivers of environmental regulations in exchange for some other action on the part of the regulated entity, if the EPA believe that the exchange would lead to better environmental results overall. For example, an Intel chip-manufacturing facility agreed to a de facto facilitywide air emissions bubble that was more stringent than would have otherwise been required by federal regulations. In exchange, Intel was relieved of the expensive requirement of seeking EPA approval for

273. Endangered Species Act § 10(a)(1), 16 U.S.C. § 1539(a)(1) \& (a)(2) (2003).

274. Id.

275. See J.B. Ruhl, Biodiversity Conservation and the Ever-Expanding Web of Federal Laws Regulating Non-Federal Land: Time for Something Completely Different? 66 U. COLO. L. REV. 555, 581 n.67 (1995); Shi-Ling Hsu, A Game-Theoretic Approach to Regulatory Negotiation and a Framework for Empirical Analysis, 26 HARV. ENVTL. L. REV. 33, 35 (2002). 
frequent and routine production process changes. ${ }^{276}$ Project $\mathrm{XL}$ is an efficiency-driven program in the sense that it contemplated the exchange of rights that hopefully inured to the benefit of both sides-to the EPA in terms of better environmental results, and to the regulated entity in terms of flexibility.

\section{Have Efficiency Programs Helped?}

The controversy over efficiency-based regulation has already raged for decades, serving to formulate and sharpen policy issues. To clarify the differences between efficiency and fairness, I focus for the most part upon how decentralized trading programs have fared, compared to traditional fairness-based programs. I discuss regulatory bargaining programs only in a few instances because while I acknowledge that significant problems remain for regulatory bargaining programs, extensive discussion of these implementation problems would detract somewhat from a meaningful comparison of efficiency and fairness. It is also worth noting that to some extent, the dichotomy between efficiencybased and fairness-based programs is a false one; environmental regulation has taken on a wide variety of forms, not all of which can be characterized as either efficiency-oriented or fairness-oriented. ${ }^{277}$ The Emergency Planning and Community Right-to-Know Act, for example, relies heavily upon requiring facilities to simply disclose possession of "extremely hazardous substances" 278 without imposing other, more onerous, regulations.

\section{Have Efficiency Programs Created Greater Democratization?}

Cass Sunstein, ${ }^{279}$ Bruce Ackerman, and Richard Stewart ${ }^{280}$ have argued that efficiency-based programs such as decentralized trading programs create a better democracy for making environmental law. They argue that when a central agency such as the EPA is charged with presuming to know and specifying an appropriate uniform standard or technology, we can expect rent-seeking behavior by those having an

276. JAMES BOYD, ET AL., INTEL's XL PERMIT: A FRAMEWORK FOR EVALUATION 7-11 (1998), at http://www.rff.org/disc_papers/PDF_files/9811.pdf.

277. See Peter S. Menell, Introduction, in INTERNATIONAL LIBRARY OF ESSAYS IN LAw AND LEGAL THEORY: ENVIRONMENTAL LAW xl-xliii (2002).

278. See Emergency Planning and Community Right-to-Know Act, $\$ 302,42$ U.S.C. $\S 11002$ (2003).

279. Cass R. Sunstein, Democratizing America Through Law, 25 SUFFOLK UNIV. L. REV. 949, 949, 957-959 (1991).

280. Bruce A. Ackerman \& Richard B. Stewart, Reforming Environmental Law: The Democratic Case for Market Incentives, 13 CoLUM. J. ENVTL. L. 171, 188-89 (1988). 
interest in adoption of a particular technology. ${ }^{281}$ By contrast, a decentralized trading program, which requires the determination of a cap level but nothing else, would force us to confront the only hard question that should be answered: "what is the appropriate level of pollution?" That this value-laden question should be answered politically is precisely the point. ${ }^{282}$

Other questions, of how a certain pollution level is to be achieved, and what technologies are to be deployed in meeting that level, are not questions that should be answered politically. These questions should be answered by the private sector, using markets and the disparate pieces of information that change from location to location, and from industry to industry. Different power plants may enjoy different comparative advantages such that the best compliance option for one plant is not necessarily the best for another. A plant on a rail line in the Midwestern United States, enjoying cheap and ready access to low sulfur coal from Wyoming, would be more likely to include low sulfur coal in its overall compliance plan, than would a plant very close to a source of high sulfur coal, which might choose to install scrubbers. The point is that we should not attempt to regulate each of these individual sources of pollution as if they were identically situated. ${ }^{283}$ Federal government should concern itself with the one question it can answer: how much total pollution should we suffer?

Has this been borne out in practice? Have we realized a more democratic way of environmental law and policymaking? Heinzerling argues that the debate over how much sulfur dioxide pollution was to be allowed under the 1990 Clean Air Act Amendments was hardly a model of "reasoned deliberation." 284 Rather, members of Congress refused to debate the emissions limitation that would be imposed in the legislation, sticking with the ten million-ton reduction in the President's original proposal. ${ }^{285}$ As a testimonial to Sunstein's naiveté, Heinzerling noted that Congress, rather than being guided by cost-benefit analysis, only ordered a cost-benefit after passage of the Amendments. ${ }^{286}$ But what is her point? Is she saying that Congress should have done a cost-benefit analysis before legislative determination of the appropriate level of the cap? With that Sunstein, Ackerman, and Stewart (and I) could not agree more.

281. See Sunstein, supra note 279 at 958-59; Richard B. Stewart, Madison's Nightmare, 57 U.

CHI. L. REV. 335, 342 (1990).

282. See Ackerman \& Stewart, supra note 280 , at $188-89$.

283. See id. at 191; cf. Sunstein, supra note 279 at $964-68$.

284. Lisa Heinzerling, Selling Pollution, Forcing Democracy, 14 STAN. ENVTL. L.J. 300, 32324 (1995).

285. Id.

286. Id. 
As it turned out, the mandated cost-benefit analysis, completed in $1997,{ }^{287}$ estimated compliance costs of the Clean Air Act from 1970 to 1990 to have been $\$ 523$ billion, but the benefits to have been a whopping $\$ 22.2$ trillion. A follow-up report in 1999 estimated the benefits of the 1990 Clean Air Act Amendments to be $\$ 110$ billion per year from 1990 to 2010 , and the costs to be $\$ 27$ billion per year. ${ }^{288}$ As argued above, these findings must have at least played a part in creating momentum to further reduce emissions, and is partially responsible for the fact that there are now three proposals pending before Congress to reduce emissions from coal-fired power plants, including the Clear Skies proposal put forth by President Bush. ${ }^{289}$ An EPA cost-benefit analysis has indicated that the President's proposal would produce more benefits than costs. ${ }^{290}$ The EPA initially declined to perform the same analyses for one of the rival proposals, prompting criticism from the sponsor, Senator Tom Carper. Carper complained that "[i]f Congress is to consider the Clear Skies Act and other proposals, it is necessary that information based on identical assumptions and modeling be made available in order to allow for fair and accurate comparisons of the alternatives." 291 Bowing to pressure, EPA recently announced that it will, after all, perform a cost-benefit analysis on the Carper proposal. ${ }^{292}$ I consider this evidence that an efficiency debate can be had, and that an efficiency debate can work. Despite the fact that a powerful and popular president attempted to load the deck in favor of his proposal, a senator from an opposing party was able to secure a promise that his proposal would be analyzed under the same conditions.

The President's Clear Skies proposal also conflicts with a proposal to limit emissions of greenhouse gases put forth by Senators McCain and Lieberman. ${ }^{293}$ The Bush administration, which opposes mandatory regulation of greenhouse gases ${ }^{294}$ has also balked at releasing its analysis of the costs and benefits of the greenhouse gas proposal. Reports indicated that the proposal would reduce greenhouse gases at very little

287. See 1997 Report, supra note 159.

288. See 1999 Report, supra note 159.

289. See supra note 160.

290. The analysis found an increase of public health benefits of $\$ 110$ billion per year by 2020 , and costs of $\$ 6.3$ billion per year. EPA, CLEAR SKIES: BASIC INFORMATION, at http://www.epa.gov/

air/clearskies/basic.html (last updated July, 2003).

291. Steve Cook, New EPA Analysis Finds Greater Benefit From Clear Skies Proposal for Power Plants, 34 ENV'T REP., July 4, 2003, at 1485.

292. EPA Will Analyze Economic, Air Impacts of Carper Bill to Control Several Pollutants, 34 ENV'T REP., July 25, 2003, at 1658.

293. Senator Lieberman is the sponsor and Senator McCain is a co-sponsor of the Climate Stewardship Act of 2003, S. 139, 108th Cong. (2003).

294. Jeffrey Ball \& John J. Fialka, Bush's Global Warming Plan Draws Heat From Businesses, WALL ST. J., Feb. 11, 2003, at A4. 
cost. ${ }^{295}$ EPA Assistant Administrator for Air Jeffrey Holmstead was reportedly heard lamenting at an EPA meeting, "[h]ow can we justify Clear Skies if this gets out?"296 This controversy has prompted William Ruckelshaus, EPA Administrator to Presidents Nixon and Reagan, to remark: "[i]s the analysis flawed? That is a legitimate reason for not releasing it. But if you don't like the outcome that might result from the analysis, that is not a legitimate reason." ${ }^{297}$ To a skeptic, this is more evidence of the shenanigans that become possible under efficiencyoriented regimes. To me, this is like blaming television for the advent of horrible reality TV programs. That cost-benefit analysis can be misused, and has been misused, is without doubt; the question is whether it will be more useful than the alternative. The public exchanges around the Clean Air Act seem to be just what Sunstein, Ackerman, and Stewart have predicted and hoped for, and indeed represent a positive development in terms of democratizing the debate.

Heinzerling also proffers the many special dispensations that came with the Title IV of the 1990 Clean Air Amendments as evidence that the $\mathrm{SO}_{2}$ emissions trading program was simply an exercise in rent-seeking and therefore a failure. Among the special dispensations were bonus emissions allowances awarded to utilities that installed scrubbers (as an incentive to continue to use high-sulfur coal) ${ }^{298}$ utilities in Indiana, Ohio, and Illinois in the years 1995-1999,299 and thereafter utilities in ten states. $^{300}$ This was indeed the ugly side of the 1990 Clean Air Act Amendments. But, was this process uglier than the way in which traditional fairness-based regulations are implemented? The burdensome, lengthy, and litigation-producing administrative rulemaking process would seem to indicate otherwise. ${ }^{301}$ Moreover, was the 1990 process not ugly because of its transparency?

The special dispensations in Title IV were the result of certain utilities being able to foist upon Congress their self-serving notions of being treated fairly. The prescription for minimizing this rent-seeking,

295. Jennifer 8. Lee, New Estimates on Emissions Plan, N.Y. TIMES (July 30, 2003) at A15.

296. Jennifer 8. Lee, Critics Say E.P.A. Won't Analyze Some Clean Air Proposals, N.Y. TIMES, July 14, 2003, at A9.

297. Id.

298. Clean Air Act $\S 405(a)(2) ; 42$ U.S.C. $\$ 7651 d(a)(2)$

299. Id. $\$ 404(\mathrm{a})(3)$.

300. Illinois, Indiana, Ohio, Georgia, Alabama, Missouri, Pennsylvania, West Virginia, Kentucky, and Tennessee each get a share of 50,000 bonus allowances. Id. $\S 405$ (a)(3).

301. Examples abound, but few misfire as dramatically as the tortuous, ten-year development of the Occupational Safety and Health Administration rule on permitted levels of benzene exposure, which included a 36,000-page report in support of its final 1987 rule. The lengthiness of the rulemaking process was caused by the Supreme Court decision in Industrial Union Department, AFL-CIO v. American Petroleum Institute, 448 U.S. 607 (1980), striking down OSHA's original determination as to the safe level of exposure to benzene. See PERCIVAL, supra note 7 , at $410,423-26$. 
however, is not to abandon efficiency-based programs entirely; the answer is to focus upon them more intensely. The fact that Congress strayed too far and too often from efficiency concerns and ate at the trough of fairness concerns instead indicates a need for more efficiencythinking, not less. Had efficiency been a more explicit focus during the development of the Title IV, it is likely that some of these special dispensations would have at least faced questions. Granted, it would not be realistic to hope that the dispensations could be avoided entirely, but they might become harder to obtain with a more explicit focus on efficiency.

ITQ programs present an interesting contrast to emissions trading programs, since fishing allowances are expressed as a fraction of the cap. In ITQ programs in the United States, the cap on the permitted quantity of fish - the total allowable catch (TAC) - is determined administratively by a regional council, composed of marine scientists, state and federal government officials, and representatives from the fishing industry and environmental organizations. ${ }^{302}$ The TAC determination process has often been fraught with ambiguity ${ }^{303}$ and, of course, rent-seeking. But again, compromises to the integrity of the TAC determination, which is meant to reflect primarily biological factors, ${ }^{304}$ have been made in the name of fairness. ${ }^{305}$ Fishermen, already wary of regulation, have successfully resisted reductions in the TAC that would result in economically painful reductions in the permitted amount of fish caught. Again, the lesson is not to blame efficiency, but fairness, for the travails wrought by special interests wielding fairness arguments.

\section{Have Efficiency Programs Addressed Capitalization Problems?}

The New Source Review Program and grandfathering under the Clean Air Act have slowed capital turnover, leading to the perpetuation of antiquated technologies. A $2002 \mathrm{GAO}$ report found that power plants in operation before 1972 emitted, per unit of electricity produced, about twice as much $\mathrm{SO}_{2}$ and twenty-five percent more NOx than was emitted by newer power plants subjected to New Source Review. ${ }^{306}$ The perpetuation of the old, coal-fired power plants that haunt our economy, our health, and our environment is clearly inefficient. ${ }^{307}$ Have

302. Shi-Ling Hsu \& James Wilen, Ecosystem Management and the 1996 Sustainable Fisheries Act, 24 ECOLOGY L.Q. 799, 801-03, 807 (1997).

303. See id.

304. Id.

305. See id.

306. U.S. Gen. ACCOUNTING Office, AIR POllution: EMISSION From Older ELECTRICITY GENERATING UNITS 3 (2002).

307. There is, of course, an efficiency argument for not immediately shutting down highpolluting plants. The "demoralization costs" of an immediate shut-down or a stringent regulation 
decentralized trading programs alleviated this problem? The answer is no, but they should have.

Fundamentally, over-exploitation or pollution problems often have much to do with the size of the initial capital investment. When the variable costs of exploitation are low relative to the costs of servicing the capital investment, the owner of the capital faces a powerful incentive to maximize use of the capital, in an effort to recoup the capital costs as quickly as possible. In the electricity generating industry, the costs of building a power plant, and of servicing the debt incurred to build it, dwarf the low fuel and maintenance costs required to produce electricity. ${ }^{308}$ Once built, the plant owners face an overwhelming incentive to run the plant as much as possible, and to resist any efforts to regulate or curtail its operation.

Fairness-thinking of another sort exacerbates this dynamic. Requiring firms to do their best with what they have creates incentives (if not mandates) for firms to spend money on capital projects for pollution control equipment. This, in turn, strengthens the sense that the firm has a vested interest in the plant (including the pollution-reducing capital equipment), and the sense that the life of the plant and capital equipment must be extended in order to recoup the upfront expenditures. ${ }^{309}$

Decentralized trading programs present no incentive to hang on to old capital equipment. In fact, the pricing at the margins of each ton of a pollutant encourages a polluting firm to re-examine its balance sheet and ask if the higher variable costs (due to the cost of the allowance) justify the attempt to recoup the capital expenditures. Thus, by reducing the huge disparity between capital and variable costs, and by avoiding the inducement of additional capital expenditures, decentralized trading programs should help usher out old technologies and usher in the new.

Why has this not been borne out in practice? As noted above, it was certainly expected that the 1990 Clean Air Act Amendments would prompt the retirement of these older, mostly coal-fired power plants, ${ }^{310}$ as it was in 1977 , when grandfathering was introduced. ${ }^{311}$ Instead, many

that takes effect immediately might be so high as to impose real economic costs, and chill investment generally for fear of such sudden governmental action. But this would be an argument for a phase-out period. Dating back to the grandfathering of old power plants under the 1977 Clean Air Act Amendments, the phase-out period for the "old dirties" has been twenty-six years and counting.

308. See U.S. ENERGY INFO. ADMIN., DEF'T OF ENERGY, ANNUAL ENERGY OUTLOOK 2003 at 78 fig.67 (2003), at http://tonto.eia.doe.gov/FTPROOT/forecasting/0383(2003).pdf.

309. Scrubbers, for example, make coal-fired power plants considerably more expensive. Scrubbers often cost over $\$ 100$ million, and account for as much as a third of total capital cost. See S. REP. No. 101-228, at 3831 (1989) (Clean Air Act Amendments of 1989, Pub. L. No. 101549).

310. See COHEN, supra note 38, at 68 .

311. See also 143 CONG. REC. E2256 (1997) (1997) (statement of Rep. Pallone) (introducing the Electricity Clean Competition Act of 1997). Representative Pallone said: 
plants are being operated well beyond their original expected useful life. ${ }^{32}$ And between 1995 and 2000, only seven coal-fired power plants were retired-a great disappointment. ${ }^{313}$ The reasons for this disappointment are complicated, but certainly a large factor is that the nationwide cap on $\mathrm{SO}_{2}$ emissions was not nearly tight enough. ${ }^{314}$ Decentralized trading programs merely remove a previously existing incentive to over-exploit or over-pollute. They cannot solve an overcapitalization problem unless the cap is tight enough to drive the variable costs up. Only when the variable costs are driven up by the cost of required allowances does it become economical to abandon an older plant and build one that would be less polluting, require fewer allowances, and therefore incur lower variable costs.

Decentralized trading programs in the form of ITQ programs have been much more successful in reducing capitalization problems in the fishing industry. Overfishing occurs because the capital cost of obtaining a boat is much more than variable fishing costs such as hired labor and gasoline. ${ }^{315}$ Because of low variable costs, additional fishing trips are cheap. Because of high capital costs, additional fishing trips are important. Boat owners must catch as many fish as possible to pay for the boat and other capital investments. Therein lies the incentive to overfish. Seemingly common-sensical and fair regulations to protect fish stocks have included the imposition of gear restrictions and seasonal restrictions. ${ }^{316}$ Yet, both of these types of measures have exacerbated the capitalization problems, and generally had disastrous ecological consequences. Seasonal restrictions only increased the pressure on regulated fisheries to absorb a short but increasingly intense fishing season. The Alaskan halibut fishery was reduced to an absurd two-day season composed of two 24-hour fishing derbies in which fishermen caught as much halibut as possible, paying no regard to ecological waste

I think that it is time we recognized that when the Congress adopted the Clear Air Amendments of 1977 , many old, dirty facilities that were expected to close down were granted exemptions to the strict air pollution control requirements that we applied to new facilities. Yet, 20 years later these grandfathered facilities continue to operate and would, in the absence of our legislation, enjoy an even greater unfair competitive economic advantage over electricity generators that have installed state-of-the-art pollution control technologies or that generate electricity using cleaner fuels or renewable resources.

Id.

312. Over forty percent of all existing power plants in operation are more than forty years old, and shockingly over sixty-five percent are more than thirty years old. NORTHEASTMIDWEST INST., supra note 80, at 26.

313. Swift, supra note 235 , at 339 .

314. Swift, supra note 235 , at 407 .

315. IUDICELLO, supra note 263 , at $76,117,163$.

316. National ReSEARCh COUNCIL, ShaRing the Fish: TOWARD a NaTIONAl POlicy ON INDIVIDUAL FISHING QUOTAS 117 (1999). 
or human safety. ${ }^{317}$ Gear restrictions have also been comically futile. Restrictions on boat lengths have been met with the entry of rounder and more powerful boats, ${ }^{318}$ while regulations on line lengths have been met by lines with more hooks. ${ }^{319}$ Meanwhile, all of the new equipment acquired to circumvent gear and seasonal restrictions has only served to raise the stake fishermen have in their capital.

In theory, ITQ programs should remove some of the perverse incentives associated with the overcapitalization of fishing boats. The value of a quota share, or fishing allowance, represents an opportunity cost to maintaining and servicing capital. All other things being equal, it is believed that less efficient fishermen will catch fewer fish and garner smaller revenues with their quota shares, and will fare poorly in comparison with their peers. The hoped-for result is that the more efficient fishermen will buy out the shares of the less efficient ones, and the less efficient ones will fish for a species that is less fragile, or even find another line of work altogether, reducing the number of boats fishing for the ITQ-regulated species.

Has this actually occurred? ITQ programs have indeed been quite successful in reducing capitalization in fishing industries. Almost uniformly, ITQ programs have achieved consolidation and reduced the number of boats, alleviating the pressure on the regulated fisheries. ${ }^{320}$ This has removed the most powerful and perverse incentive to overfish.

In sum, decentralized trading programs have had only mixed success in addressing the capitalization problems created by fairness-oriented regulation. While ITQ programs have vindicated economic theory, the $\mathrm{SO}_{2}$ emissions trading program has not. The devil, however, is in the details. In order for decentralized trading programs to reduce capitalization, the cap must be set tightly enough to represent an actual constraint on polluting activity. Otherwise, there is no stringency to the regulation. This is what befell the $\mathrm{SO}_{2}$ emissions trading program.

ITQ programs also illustrate quite nicely why it is so tempting to regulate using a fairness-oriented approach, even if ineffectual. It is easy to set up a fair race to fish, whether by contracting the fishing season or setting gear restrictions. These restrictions are fair-everyone is prohibited from using the same gear. None of the participants will complain that it is inefficient, however, and no one represents the future generations that will be left with far fewer fishing resources.

317. IUDICELLO, supra note 263 , at 137-38.

318. NATIONAL RESEARCH COUNCIL, supra note 316, at 117 (1999).

319. IUDICELLO, supra note 263 , at 81 .

320. Id. at $114,134,142-43,144$ fig. $6.11,145$ fig. 6.12 . 


\section{Have Efficiency Programs Reduced Costs?}

Economic efficiency has many components, but this section focuses on two aspects: minimizing compliance costs and minimizing administrative costs.

\section{a. Minimizing Compliance Costs}

It was a subconsciously distributive sense of fairness that prompted Congress to require the imposition of nationally uniform standards of effluent discharge under the Clean Water Act and, as a general matter, nationally uniform emissions standards under the Clean Air Act. ${ }^{321}$ The problem, from an economic point of view, is that marginal abatement costs are likely to vary greatly across facilities and across regions of the country. For some facilities, achieving a given effluent discharge or emission limit will be costly; for others, quite inexpensive. The problem with nationally uniform standards is that they do not discriminate.

Foremost among the advantages of efficiency-based programs is the potential to achieve greater economic efficiency through trading. In decentralized trading programs, efficiency is achieved when allowances to pollute, fish, or develop land gravitate towards those that can make the highest and best use of the allowance. Gains from trading pollution allowances result because facilities with higher marginal abatement costs will place a higher value on having an allowance than facilities with lower marginal abatement costs and will pay the latter for their allowances. The overall societal result is that the reduction in emissions imposed by the emissions cap will be accomplished at the lowest overall cost. ${ }^{322}$ A second reason that decentralized trading programs lead to economic efficiency is that polluting firms may be able to choose from a greater variety of compliance strategies than they would have under traditional fairnessbased schemes. This flexibility necessarily lowers compliance costs.

The empirical evidence on whether gains from trading have occurred is clearly positive. Lower-than-expected allowance prices suggest unanticipated cost savings that would not have been identified under more rigid fairness-based programs. Early predictions of $\mathrm{SO}_{2}$ emissions allowances put the value of allowances in the $\$ 300-\$ 400$ per ton range,

321. The Clean Air Act does roughly discriminate based on how dirty the receiving air is, by calling for the designation of "attainment" and "non-attainment" areas. Clean Air Act $\$$ $110(\mathrm{a})(2)(1) ; 42$ U.S.C. $\$ 7410$ (a)(2)(1) (2003).

322. This dynamic is believed to accomplish the same kind of efficiency in fisheries governed by an ITQ program. Advocates of ITQ programs have predicted that the most efficient fishers would buy out the less efficient fishers, again dirccting the rights to their highest and best use. Alison Rieser, Prescriptions for the Commons: Environmental Scholarship and the Fishing Quotas Debate, 23 HARV. ENVTL. L. REV. 393, 414 (1999); Hsu \& Wilen, supra note 302, at 808. This is, in essence, a reduction in pollution in that catching fish at lower cost is equivalent to producing electricity at a lower compliance cost. 
but as it turned out, prices dipped to as low as $\$ 65$ per ton in $1996,{ }^{323}$ before rebounding to $\$ 180$ in August, $2003 .{ }^{324}$ Under another program, established by a special statutorily-mandated Northeastern regional entity, the Ozone Transport Commission, ${ }^{325}$ an NOx emissions trading program was established to deal with the region's chronic and severe ozone problem. The emissions trading program was overlaid on top of the Title IV traditional fairness-based regulation, as well as other NOx regulations. Allowance prices debuted in 1999 at approximately $\$ 2000$ per ton, but have since dropped to $\$ 750$ per ton, ${ }^{326}$ suggesting substantial compliance cost savings in that program as well.

Cost savings have been confirmed on a larger scale as well. Analysis by researchers at Resources for the Future has found trading opportunities under the $\mathrm{SO}_{2}$ emissions trading program worth as much as $\$ 250$ million. ${ }^{327}$ Denny Ellerman has estimated the cost savings of trading to have been $\$ 358$ million per year from 1995-1999 (Phase I of the Acid Rain Program), and as much as $\$ 2.3$ billion per year for 2000-2007 (Phase II \& banking). ${ }^{328}$ And because of consolidation in the electricity generation industry, it seems likely that what were once trading opportunities between different firms have now become opportunities to realize savings through intra-firm adjustments.

Decentralized trading programs are also likely to be more economically efficient in that the flexibility afforded to firms enables them to coordinate compliance strategies with each other. The trading of emissions permits is not only a form of least-cost compliance, but also a way of coordinating who will pollute. And because emissions allowances can be "banked" for future use, they also allow polluting firms to allocate when they will pollute. The advantages of coordination have been even more important in ITQ programs. Under the erstwhile two-day Alaskan halibut derby fishery, fishing boats would line up twice a year en masse for a 24-hour race to fish, in which they would catch as much halibut as they could, incur numerous risks, lose a great deal of valuable gear, and inflict colossal damage upon the stocks of a variety of fish species other than halibut. ${ }^{329}$ Even worse, because of the twice-a-year halibut glut,

323. ELLERMAN, supra note 159, at 172-73.

324. See Cantor Fitzgerald, Market Price index, at http://www.emissionstrading.com/ index_mpi.htm (last visited Apr. 28, 2004).

325. Clean Air Act $\S 184 ; 42$ U.S.C. $\$ 7511$ c (2003).

326. Steve Cook, Eastern States Claim 60 Percent Reduction in Emissions of NOx Since 1990, 34 ENV'T REP., Mar. 7, 2003, at 519.

327. RFF Report, supra note 159 , at 1318 tbl.3.

328. ELLERMAN, supra note 159, at 282.

329. Millions of dollars of gear were lost, millions of dollars of damage was inflicted in terms of fish accidentally killed by the lost gear, and halibut fishing became the second-most dangerous job in the United States. Rieser, supra note 322, at 412-13 (1999). 
virtually all of the halibut caught by Alaskans were sold to the frozen fish market. ${ }^{330}$ By contrast, halibut fishermen based in British Columbia operated under an ITQ system, and used their quota to coordinate and spread out fishing efforts so that halibut could be caught and sold yearround into the much more lucrative fresh fish market. ${ }^{331}$ The British Columbia ITQ program, by removing the incentive to race to fish, in effect granted the fishermen a more complete right, and allowed them to fish under less stressed and more efficient conditions.

Economic theory thus seems to have been for the most part vindicated by decentralized trading programs thus far. The cost savings realized by electricity generating firms and fishermen have been substantial.

\section{b. Minimizing Administrative Costs}

Fairness-thinking can result in a complicated maze of regulations, making administration difficult, time-consuming and costly. Section 301 of the Clean Water Act, for example, requires the EPA to set different effluent discharge regulations for every type of point source polluter. ${ }^{332}$ This involves establishing regulations for not only the twenty-seven industrial categories specified in the Act, ${ }^{333}$ but also 180 subcategories and forty-five other classifications. ${ }^{334}$ And certainly, it has been difficult for EPA to administer the many different emissions standards for emissions of NOx from power plants.

Dan Cole and Peter Grossman argue, however, that the traditional "command-and-control" 335 regulatory structure (fairness-based regulation, in my parlance) was actually the least expensive way of reducing emissions from the government's perspective. ${ }^{336}$ Simple enforcement rules, especially when an agency lacks the ability to monitor quantities of emissions, may well have been the only feasible alternative. This observation was almost certainly true when most of our environmental statutes were passed and regulations written. ${ }^{337}$ Even now,

330. IUDICELLO, supra note 263 , at $137-38$.

331. Id. at 152.

332. Supra note 237.

333. See Federal Water Pollution Control Act $\$ 307(b)(1), 33$ U.S.C. $\$ 1316(b)$ (1) (2003).

334. PERCIVAL, supra note 7, at 682.

335. "Command and control" is the pejorative term used by advocates of efficiency-based programs to describe the centralized nature of certain performance standards. Some performance standards are such that only one known technology is sufficient to meet the standard, and thus it becomes the default technology. Driesen takes exception to this phrasing, noting that most fairness-oriented performance standards actually permit the usc of more efficient technologies. DRIESEN, supra note 12 , at 51-52.

336. Cole \& Grossman, supra note 12, at 918-20.

337. Enforcement problems were central to the determination that technology-specific standards were necessary under the 1972 Clean Water Act. Andreen, supra note 238, at 270. 
since we lack monitoring technology to measure and enforce quantitative limits of some pollutants, a regulation that is predicated on particular technologies may still be more effective than a decentralized trading program. Without monitoring technology, decentralized trading programs make no sense at all, since polluters would be able to pollute with impunity whether they held allowances or not.

Given the need for monitoring and enforcement methods in decentralized trading programs, have these programs vindicated predictions of greater administrability? Again, the evidence is scant but states reasonably clearly that the answer is yes. Under Title IV, the $\mathrm{SO}_{2}$ emissions trading program has achieved a one hundred percent compliance rate thus far, and done so with a small EPA staff. ${ }^{338}$ By contrast, the staff of hundreds administering the companion NOx program has been kept busy administering the complex schedule of NOx regulations. ${ }^{339}$ The savings come from the fact that under the $\mathrm{SO}_{2}$ emissions trading program, the EPA is charged only with ensuring that an emitter possesses the requisite number of allowances to cover the actual quantity of emissions. This task is made much simpler by the continuous emissions monitors that are required to be installed in every power plant.

Cole and Grossman's admonition seems to ring more true with respect to ITQ programs. The results have been mixed, with a majority of ITQ-governed fisheries experiencing increases in administration and enforcement costs. ${ }^{340}$ However, in many cases, increases in costs result from the difficulty of starting from scratch, with respect to enforcement. That is, cost increases sometimes came about because the enforcement regime that came before ITQs was so abysmally ineffective that significant costs were necessary in any case, whether that regulation took the form of ITQs or gear restrictions. ${ }^{341}$ ITQs also have the practical advantage of being susceptible of a tax, or landing fee, that can recoup some administrative costs. ${ }^{342}$

It seems safe to conclude that decentralized trading programs can achieve substantial administrative cost savings, but are infeasible unless reliable and affordable means of monitoring and enforcement are available. But there is a chicken or the egg problem inherent in waiting for monitoring technologies to develop before implementing a decentralized trading program. Monitoring technologies will be slow to develop unless there is an incentive to develop them, which there won't be unless there is a regulatory commitment to decentralized trading

338. Byron Swift, The Acid Rain Test, 14 ENVTL. F., May-June 1997, at 17, 24 (1997).

339. Id.; Swift, supra note 235 , at 387-88.

340. NATIONAL RESEARCH COUNCIL, supra note 318, at 175-76.

341. Id. at 175.

342. Id. at $366-67$. 
programs ${ }^{343}$ Even now, some promising technologies seem to be poised on the cusp of a breakthrough that would make them operational and pave the way for implementation of a decentralized trading program. For example, remote sensing technology can identify soil properties by their spectral signals ${ }^{344}$ detect concentrations of chlorophyll that may be caused by nutrient runoff, ${ }^{345}$ and even model the amount of nutrient runoff from poultry farms. ${ }^{346} \mathrm{Can}$ we really be so far away from developing monitoring technology that would make possible a decentralized trading program for non-point source water pollution? The problem is, however, that the political volatility of regulating non-point source pollution may discourage private entrepreneurs from investing in the development of such technology since demand would only exist if a pollution trading program were adopted. Alternatively, governmental agencies could directly subsidize the development of monitoring technologies. Private energies in search of private profits, however, have generally yielded better results and more quickly.

\section{Have Efficiency Programs Created Incentives for Innovation?}

Economic efficiency may also be considered in a dynamic sense, the degree to which there is innovation that reduces the cost of pollution abatement. Proponents of decentralized trading programs argue that such programs present incentives to produce innovations that increase the efficiency of pollution abatement. ${ }^{347}$ The argument is that because a marginal price is placed on the emission of every ton of pollutant, polluters have an incentive to find ways to reduce pollution, to minimize

343. The converse may also be true. Driesen has argued that the development of good monitoring technology may never come about if regulatory agencies are fixated on decentralized trading programs and will proceed even without monitoring technology. David Driesen, Choosing Environmental Instruments in a Transnational Context, 27 ECOLOGY L.Q. 1, 8 (2000). This may not necessarily be true, however. If poor monitoring technology is put in place, those who stand to gain from good monitoring technology - those who can make the most money reducing emissions - will press for better technology, and may finance development of better technologies themselves.

344. Kenneth J. Markowitz, Legal Challenges and Market Rewards to the Use and Acceptance of Remote Sensing and Digital Information As Evidence, 12 DUKE ENVTL. L. \& POL'Y F. 219, 230 (2002).

345. The National Oceanic and Atmospheric Administration has been using aircraft to collect data on chlorophyll concentrations in the Chesapeake Bay. NAT'L OCEANIC \& AtMospheric Admin., Chesapeake Bay aircraft Remote SENSING, http://noaa.chesapeakebay.net/facts/Factsheet_remote_ sensing.pdf (last updated Aug. 20, 2002).

346. I. ChAUbEY, ET AL., USING GIS, REMOTE SENSING AND WATER QUAlity MODELING to Estimate ANIMAL WASTE POLlution POTENTIAL (2000), available at http://www.ag.auburn.edu/ nsdl/sctcsa/Proceedings/2000/Chaubey_a.pdf.

347. This is an often-made argument. See, e.g., David Driesen, Does Emissions Trading Encourage Innovation? 33 ENVTL. L. REP. 10,094, 10,094, n.1 (2003). 
the number of allowances they will need to buy. This introduces continuous incentives to polluters to find ways to reduce pollution, and rewards those who innovate in reducing pollution.

A number of arguments have emerged to challenge this idea. Scott Barrett has made an ingenious argument in defense of fairness-based performance standards. In arguing for an alternative to the Kyoto Protocol for controlling greenhouse gas emissions, Barrett notes that many of the technologies of reducing greenhouse gas emissions have two characteristics: strong network externalities ${ }^{348}$ and economies of scale. ${ }^{349}$ The problem with greenhouse gas reduction technologies is likely to be the uncertainty that they will be needed. With a number of implementation issues still unresolved, ${ }^{350}$ and the Kyoto Protocol itself still awaiting ratification by the Russian Republic in order to enter into force, ${ }^{351}$ the development of greenhouse gas reduction technology has been stunted. Also uncertain is the degree to which non-signatories such as the United States will be punished for non-participation. ${ }^{352}$ By mandating performance standards, Barrett argues, a treaty can (1) guarantee a volume of business sufficient to induce investment in the development of technologies, and (2) provide incentives for countries to sign on, for fear that they will otherwise lack access to a standardized means of production. ${ }^{353}$

David Driesen has carried on a more sustained attack on the idea that decentralized trading programs induce more innovation than fairness-based programs. ${ }^{354}$ In a decentralized trading program, Driesen argues, there are by definition the same number of potential buyers and sellers of pollution allowances. It is therefore wrong to say that all firms will face an incentive to innovate, because some will buy credits instead

348. That is to say, the use of a product becomes more valuable the more parties there are that use it. Examples include telephones and e-mail, and some environmental technologies such as electric vehicles, that might require a network of recharging stations. See BARRETT, supra note 252 , at $261-62,395$.

349. Id. at 395 .

350. For example, only recently did the European Union finally give Russia and Cananda what it refused to give the United States: agreement with the concept of allowing the generation of carbon credits for developing carbon "sinks" that absorb carbon. Maintaining and re-planting forests and certain agricultural practices could accomplish this. BARRETT, supra note 252 , at 371-73.

351. See supra note 254; see also Lawrence J. Speer, Economic Interests Said to Be Holding Back Russian Ratification Vote on Kyoto Protocol, 34 ENV'T REP., May 2, 2003, at 988.

352. In international agreements, some form of trade sanction is typically necessary to induce participation. Otherwise, the agreement could suffer from a leakage problem, similar to that which makes the Kyoto Protocol problematic, due to the non-participation of developing countries. See supra note 251. Furthermore, without trade sanctions, non-participation will have no downside, as non-signatories could free-ride off of the efforts of signatory nations to reduce pollution to the benefit of all. See BARRETT, supra note 252, at 219-20.

353. BARRETT, supra note 252 , at $395-98$.

354. See Driesen, supra note 347 , at 10,095-97. 
of innovating. The correct question to ask is whether innovation is induced by the shift, under decentralized trading programs, of pollution reduction efforts from high-cost facilities-those for which it is expensive to reduce pollution - to low-cost facilities. ${ }^{355}$ The theory behind emissions trading is that if an industry must reduce emissions by a certain amount, that amount might as well come from those facilities that in toto can most cheaply accomplish the reduction. The question is whether this shift induces innovation any more effectively than a fairness-based program of equal stringency. ${ }^{356}$

Driesen argues that over time, high-cost fixes can become low-cost fixes. ${ }^{357}$ It is certainly true that research and development have driven down the costs of some technologies, often dramatically. But there is no reason to believe that this occurs any more frequently when we coerce some polluters to adopt specific high-cost technologies, as fairnessprograms do, than if we allow them to choose technologies. Indeed, our intuition ought to be the opposite - that we will get more innovation by allowing regulated firms the maximum amount of flexibility. Fairnessbased programs narrow the range of compliance options by specifying the available options. Firms thus have a narrower field in which to innovate.

A qualitative study seems to confirm this. Title IV provides an opportunity to compare a decentralized trading program-the $\mathrm{SO}_{2}$ emissions trading program - with a traditional fairness-based program the system of differential NOx emissions limitations. It appears that the $\mathrm{SO}_{2}$ emissions trading program has fared better than the NOx regulations in terms of inducing innovation.

In the meantime, there has been only minor innovation in controlling NOx emissions from coal-fired power plants. The predominant NOx emissions control technology is the same as it has been for a decade - the installation of low-NOx burners. ${ }^{358}$ Meanwhile, firms have found a plethora of ways to reduce emissions of $\mathrm{SO}_{2}$. Power plants subject to the $\mathrm{SO}_{2}$ emissions trading program have utilized no fewer than ten strategies for complying with the $\mathrm{SO}_{2}$ emissions trading program, ${ }^{359}$ where previously there was only believed to be one-end-of-pipe flue gas

355. See id. at 10,096-10,101.

356. See.id.

357. See id.

358. Swift, supra note 235 at 365-66. "Overfire air" NOx emissions control has been available for a decade, but has been resisted by utilities because of its expense. Ala. Power Co. $v$. EPA, 40 F.3d 450 (D.C. Cir. 1994). Recently, technologies such as "Selective Catalytic Reduction" and "Selective Non-catalytic Reduction" have been adopted at some power plants, at considerably greater expense. ARNOLD W. REITZE, AIR POLLUTION CONTROL LAW: COMPLIANCE AND ENFORCEMENT, § 3-5(c) (Environmental Law Institute, 2d. ed. 2004) (draft on file with author). However, recent adoption of these new technologies may be driven by the advent of NOx trading programs. See supra note 227.

359. Swift, supra note 235 at 327-28. 
desulfurization, or "scrubbing." In addition, the existence of multiple compliance options lit a fire under the previously moribund scrubber industry. In essence, scrubber manufacturers faced competition for the first time, and they responded with a number of cost-saving innovations. ${ }^{360}$ After rail shipping costs declined enough to make importing low-sulfur coal from Wyoming's Powder River Basin economical, scrubber prices suddenly fell sharply. ${ }^{361}$ While such a development might not seem to be an "innovation," the important thing is that it was an unticipated cost-saving measure.

It might be argued that many of the $\mathrm{SO}_{2}$ compliance strategies were made possible by the seemingly serendipitous rail deregulation of the late 1980s, which made economical the shipment of low-sulfur Wyoming coal to plants on the East Coast. ${ }^{362}$ However, this argument is too simplistic for two reasons. First, the $\mathrm{SO}_{2}$ emissions trading program was necessary to allow firms to take advantage of the full array of compliance options. Different firms used different strategies to comply with Title IV, and a more traditional form of regulation would have robbed them of the ability to choose the one most appropriate for them, including the shipment of coal from far-away places. Second, it is only in hindsight that we see a plethora of options for reducing $\mathrm{SO}_{2}$ emissions. A number of compliance options might never have been discovered had a profit motive not existed to spur their discovery. For example, it was previously thought that blending a mix of high- and low-sulfur coal was technically impossible. Only after experimentation with small quantities of low-sulfur coal blended with high-sulfur coal did firms decide to take the risk of using blends as a compliance strategy. ${ }^{363}$ It is hard to imagine such risktaking under a more traditional regulatory scheme such as that used for NOx emissions.

This leads into another point that has not yet been reported in the literature. By imposing a marginal price on emissions of $\mathrm{SO}_{2}-$ that price being the market price of an $\mathrm{SO}_{2}$ emissions allowance - the $\mathrm{SO}_{2}$ emissions trading program forced a different sector of the corporation to seriously consider ways to reduce pollution. Before the 1990 Clean Air Act Amendments, pollution reduction in electricity generating firms was the domain of environmental engineers which, like the lawyers advising the firm on environmental compliance, were considered an annoyance to the business sector of the corporation. However, once a marginal price was placed on emissions, the business sector became engaged in the business

360. See Dallas Burtraw, Cost Savings, Market Performance, and Economic BENEFITS OF THE U.S. ACID RAIN PROGRAM 4 (1998), available at http://www.rff.org/Documents/RFF-DP-98-28-REV.pdf; Swift, supra note 339, at 23.

361. See Swift, supra note 339, at 23.

362. See id. at 17.

363. Swift, supra note 235 , at 335-37. 
of reducing pollution. In interviews with hundreds of officials at electricity generating firms throughout the United States and in a wide variety of capacities-engineers, compliance officers, and business strategists-Byron Swift, Lee Paddock, and researchers at the Environmental Law Institute (including myself) found that under Title IV, $\mathrm{SO}_{2}$ emissions reduction became an integral concern of the dynamic business side of the corporate entity, instead of being relegated to an isolated group of environmental engineers. As a result of this new focus on pollution reduction, the entrepreneurial energies of firms became focused upon pollution reduction, with the result that much more dynamic and unexpected solutions emerged. ${ }^{364}$

Finally, one must observe the litigation that has plagued fairnessbased programs, and wonder if resources devoted to litigation might have been resources that could have been used in research and development. It is impossible to say for sure, but the litigation over the Title IV NOx rules ${ }^{365}$ poses a stark contrast to the one hundred percent compliance rate for the $\mathrm{SO}_{2}$ emissions trading program. This strongly suggests that requiring high-cost pollution reduction measures-as fairness-based programs do-will not spur innovation to reduce the high costs, but will spur litigation instead. This is the heart of my argument: that fairness-

364. Byron Swift discusses the profit-making and arbitrage opportunities presented by trading. See supra note 235, at 341-48. In particular, Swift notes that trading "allowed the greater integration of an environmental parameter into the economic decision-making of firms." $I d$. at 342. Also, Swift noted that trading has caused "a revolution in compliance behavior because it broadly moves consideration of pollution effects into mainstream company decisions." $I d$. at 348 . This point has been made tangentially in other writings. The study of "industrial ecology" has examined how firm practices and firm organization are critical in creating more environmentally-benign products. See e.g., Patricia S. Dillon, Implications for Industrial Ecology for Firms, in THE GREENING OF INDUSTRIAL ECOSYSTEMS 202-05 (Braden R. Allenby \& Deanna J. Richards eds., 1994) ("In most cases, technology probably will not be the limiting factor, a lesson learned in recent years as companies have adopted pollution prevention practices. Rather, cultural and organizational changes within industry (as well as changing the behavior of consumers and government agencies) will most likely present greater obstacles."). Some firms have built-in organizational checks to ensure that environmental considerations are taken into account at the product development stage, practices known as "Design for Environment," and "Total Quality Management." See id. at 204-205; see also Braden R. Allenby, Integrating Environment and Technology: Design for Environment, in THE GREENING OF INDUSTRIAL ECOSYSTEMS 139 ("As a practical matter, the only way the five principles enumerated above can be implemented by industry in practice ... is by driving environmental considerations and constraints into the design process."). Such programs, however, are still artificial constraints adopted by firms to address "hidden costs" not reflected in traditional accounting practices. Deanna J. Richards et al., Overview and Perspective, in THE GREENING OF INDUSTRIAL ECOSYSTEMS 15. The formidable challenge for environmental law is to break down the "green wall" that separates environmental compliance decisions from other corporate decisions, and align private incentives with environmental goals. Swift, supra note 235, at $391 \mathbf{n}$. 381 (2001).

365. Industries seeking to overturn EPA's requirement of an additional NOx reduction technology challenged EPA's initial NOx regulations. Ala. Power Co. v. EPA, 40 F.3d 450 (1994); cf. supra text accompanying notes 338-339 (discussing administrative costs). 
based regulation spawns fairness claims and litigation, and the efficiencybased regulation is more likely to spawn innovation, or at least removes the incentive to litigate once the program is established.

The evidence, though somewhat thin, suggests that decentralized trading programs have been much more effective in stimulating innovation in pollution reduction. Decentralized trading programs offer a wider range of compliance options and afford firms greater flexibility, which provides more opportunities for innovation. Decentralized trading programs also seem to have liberated private resources previously earmarked for rent-seeking and litigation, some of which are now being used for innovation.

\section{Have Efficiency Programs Resulted in Improvements in Environmental Quality?}

Innovation may lead to reduced costs of pollution abatement, but what's in it for the environment? Have efficiency programs led to any innovation in the reduction of pollution itself? More generally, have efficiency programs led to any improvements in environmental quality?

Driesen has argued that environmental improvements depend on the stringency of a program, not on whether it is an emissions trading program or a traditional program (which I call a fairness-based program). ${ }^{366}$ As a theoretical matter, he is correct. By definition, a decentralized trading program allows aggregate emissions at or below the capped level. A decentralized trading program and a fairness-based program calibrated to achieve a specific quantity of emissions ${ }^{367}$ would result in the same aggregate quantity of emissions. Indeed, it seems obvious that it is the stringency of the limits much more than the type of program that determines pollution levels.

But the assumptions required to reach this theoretical result are too heroic. For one thing, it would be impossible to calibrate a schedule of NOx emissions rates to achieve a particular aggregate quantity of emissions. The shifting of loads from lower-polluting power plants to higher-emitting ones can foil a regulatory attempt to reduce aggregate emissions. But more importantly, this line of argument ignores the economic realities of litigation. Requiring firms to install high-cost pollution control equipment will not force them to install high-cost

366. See Driesen, supra note 347 , at 10,096 .

367. Actually, the right comparison, according to Driesen, is between an emissions trading program and a fairness-based program that is mass-based, which specifies a particular quantity of emissions for each polluter. Examples of such programs are few, however. The program to phase out of ozone-depleting chemicals was a mass-based program that was formally a trading program, but induced little trading. E-mail from David Driesen to Shi-Ling Hsu (July 7, 2003) (on file with author). 
pollution control equipment, but will instead drive them to litigation. This will keep emissions high, at least while litigation is pending, and longer still if the litigation is successful. Decentralized trading programs, by decreasing compliance costs, make the imposition of a tighter cap on emissions more palatable to the regulated industry. This argument is lost on those with a retributive sense of fairness who wish to punish polluters: changing the economics of compliance has a profound effect on environmental quality. The fact that decentralized trading programs are preferable to regulated industries is closely related to the environmental question. Like it or not, the environmental targets that regulated firms are willing to achieve are of great importance, because resistance on their part will increase emissions.

Again, the contrast in the post-implementation experiences provided by the $\mathrm{SO}_{2}$ emissions trading program and the litigation-plagued $\mathrm{NOx}$ program is illustrative. Figure 1 below shows the emissions from coalfired power plants nationwide for 1990-2001. 
Figure 1.

$\mathrm{SO}_{2}$ and NOx Emissions, 1990-2001

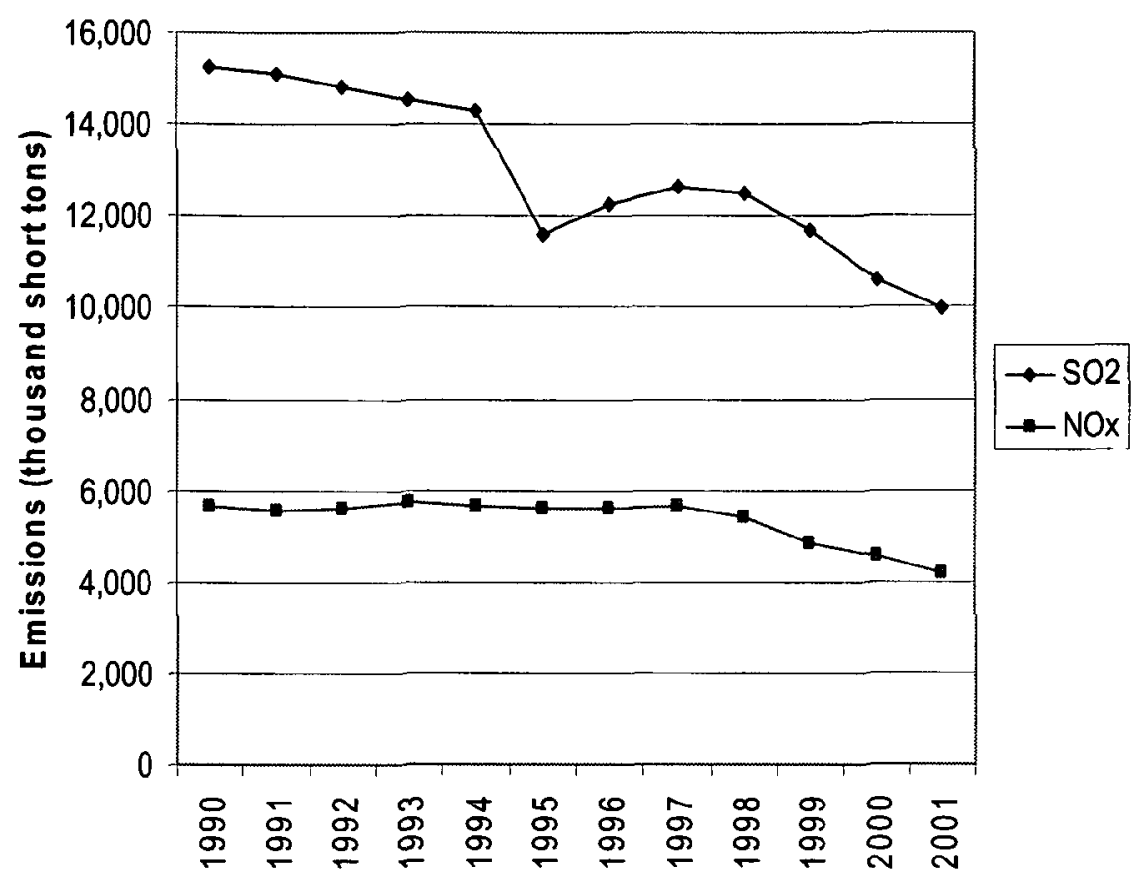

Source: U.S. Environmental Protection Agency, National Emission Inventory, Air Pollutant Emission Trends, http://www.epa.gov/ttn/chief/trends/index.html (2003)

While emissions of both $\mathrm{SO}_{2}$ and $\mathrm{NOx}$ have declined during the period in which Title IV has been in effect, $\mathrm{SO}_{2}$ emissions have declined more sharply. Between 1990 and 2001, $\mathrm{SO}_{2}$ emissions declined by thirtyfive percent, while NOx emissions declined by twenty-six percent. If one also subtracts out the 290,000-ton NOx emissions reduction accomplished by NOx emissions trading in the Northeastern United States, ${ }^{368}$ then the nationwide NOx emissions reduction drops to only twenty-one percent.

368. The states in the Ozone Transport Commission adopted a NOx trading program within the 13-jurisdiction area, and achieved a 290,000-ton reduction in NOx emissions, which the Commission has attributed to the NOx emissions trading program. Cook, supra note 326, at 519. 
While the $\mathrm{SO}_{2}$ cap obviously has a great influence on $\mathrm{SO}_{2}$ emissions, overcompliance has accounted for some additional reductions. ${ }^{369}$ In the face of lower-than-expected allowance prices, firms have opted to purchase a safety margin by buying extra allowances. ${ }^{370}$ Why NOx emissions have been flatter is impossible to tell, but enforcement problems, imperfect operation of low-NOx burners, and litigation are likely suspects. The comparison of NOx emissions with $\mathrm{SO}_{2}$ emissions, from the same regulated sources, seems to suggest strongly that the efficiency-based $\mathrm{SO}_{2}$ emissions trading program has been more effective in achieving emissions targets than the traditional fairness-based NOx regulations.

The evidence that ITQ programs have helped restore fish stocks is also positive, but less clear. Stocks of most fish species in New Zealand and Iceland governed by ITQ programs appear to have enjoyed a rebound, ${ }^{371}$ while for many other fish under ITQ programs, the data are still inconclusive. ${ }^{372}$ Many of the ITQ programs are too new to yield any meaningful statistical comparisons of the fishery before and after the program. ${ }^{373}$ There are, however, pieces of information suggesting recoveries in ITQ-regulated fisheries, such as decreases in mortality and increases in catch value, and evidence that fishing practices under ITQ programs are less wasteful in both an economic and ecological sense. ${ }^{374}$ One design problem with ITQ programs is the fact that the total allowable catch permitted is still determined each year by a regional fisheries management council, the type of body that has failed fisheries so many times in the past. ${ }^{375}$ Were the total allowable catch determination

369. ELLERMAN, supra note 159, at 149-54. In fact, in the years 1995 to 1997 , the allowances produced by overcompliance well-exceeded the amount used immediately to cover emissions. See id. at 147-148, fig.6.2 \& fig.6.3 (showing sources of excess allowances, and uses to which they were put).

370. See id. at 149-50. $\mathrm{SO}_{2}$ emissions allowances have also been "banked" for future use, raising the prospect that emissions may be higher than normal in future years. However, allowance prices remain high (see supra note 324), suggesting that firms remain wary of using up allowances. One possibility is that electricity generating firms are aware and have been aware for some time of the possibility of a tightening of the $\mathrm{SO}_{2}$ emissions cap, now seemingly inevitable in light of three legislative proposals to do so.

371. NATIONAL RESEARCH COUNCIL, supra note 318 , at 84-85, 92.

372. Id. at 74-75.

373. For example, the Alaskan halibut and Sablefish ITQ programs were instituted in 1995, id. at 308, the Surf Clam and Ocean Quahog ITQ program in 1990, id. at 289, and the South Atlantic Wreck fish ITQ program in 1992-1993. IUDICELLO, supra note 263, at 130.

374. For example, halibut mortality appears to have decreased under the Alaskan halibut ITQ program. IUDICELLO, supra note 263, at 141, 146. And while reported landings of Alaskan halibut and sablefish have decreased, the value of halibut and sablefish quota shares has increased. See id. at 142-45. Similar results have obtained for the quahog fisheries under ITQ programs, see id. at 122-25, and the South Atlantic wreckfish fishery, see id. at 129-35, although researchers have been somewhat hesitant to attribute the economic gains to the ITQ program. See id. at 132.

375. See Hsu \& Wilen supra note 302, at 803-04. 
insulated from pressure from fishermen, the record of ITQ programs might be better. Like the $\mathrm{SO}_{2}$ emissions trading program, what makes a program more environmentally successful is simply, and obviously, a more stringent cap.

Detractors of decentralized trading programs also argue that there is an inherent danger in giving up control over pollution by any one source. This seems to be the basis for an argument frequently leveled against decentralized trading programs: that they confer upon regulated parties a right they should not enjoy - the right to pollute or exploit, a right that fundamentally belongs to the public. ${ }^{376}$ Since one polluter has the right to comply by simply buying up allowances, it may create a "hot spot," or a localized area suffering from a high concentration of pollution. ${ }^{377}$

Hot spots have not materialized under the $\mathrm{SO}_{2}$ emissions trading program. Only one electricity generating firm opted to comply solely by buying enough $\mathrm{SO}_{2}$ emissions allowances to cover its emissions. But because the initial allocation of allowances was far less than that of historical emissions, the firm wound up with a net decrease in $\mathrm{SO}_{2}$ emissions. ${ }^{378}$

Economic logic explains why hot spots have yet to present a problem. ${ }^{379}$ If the price of allowances is high, it would be very expensive for a polluter to simply pollute and buy allowances to cover emissions; under such circumstances, there is a very strong incentive for that polluter to find a way to reduce emissions. If the price of allowances is low, this incentive is quite weak. But what does it mean if the price of allowances is low? It means that the cost of reducing emissions is low; if the cost of reducing emissions was high, polluters would pay dearly at the margins for extra allowances, driving up the cost of allowances. A low

376. Gerald Torres, Who Owns the Sky?, 19 PACE ENvTL. L. REv. 515 (2002); Curtis Moore, The Impracticality and Immorality of Cost-Benefit Analysis in Setting Health-Based Standards, 11 TUL. ENVTL. L.J. 187 (1998); Jane B. Baron \& Jeffrey L. Dunoff, Against Market Rationality: Moral Critiques of Economic Analysis in Legal Theory, 17 CARDOzo L. REV. 431 (1996).

377. Jonathan Remy Nash \& Richard L. Revesz, Markets and Geography: Designing Murketable Permit Schemes to Control Local and Regional Pollutants, 28 ECOLOGY L.Q. 569, 572 (2001); see also Ackerman \& Stewart, supra note 280, at 187.

378. Swift, supra note 235, at 345 . Illinois Power purchased allowances that permitted it to emit forty-four percent more than its initial allocation of allowances permitted. However, since the initial allocations were based upon a formula of roughly one-half of historical emissions, their compliance strategy amounted to a small net decrease. Id.

379. Richard Drury has argued that the Los Angeles basin's RECLAIM emissions trading program has resulted in a hot spot. One aspect of the RECLAIM program allowed Unocal to pay to scrap old, high-polluting automobiles in exchange for higher emissions at one of Unocal's marine terminals. This likely led to an increase in emissions near the marine terminal, since the emissions reductions, if there were any, came from cars that were probably distributed throughout the L.A. basin, while the emissions increase occurred at the marine terminal. Richard Toshiyuki Drury et al., Pollution Trading and Environmental Injustice: Los Angeles Failed Experiment In Air Quality Policy, 9 DUKE ENVTL. L. \& POL'Y F. 231, 235, 251-52 (1999). This aspect of the RECLAIM program, however, is not a decentralized trading program. 
allowance price means that polluters have figured out inexpensive ways to reduce pollution, and are thus unwilling to pay very much for an allowance. But a low allowance price reflects a low marginal abatement cost, and renders it less likely that a firm will pollute so much as to create a hot spot, because it is so cheap to reduce emissions. A hot spot will thus only form if one polluter's costs deviate far from that of the other polluters, making it economical to buy up many allowances.

That having been said, it is too much to say that hot spots will never occur, and that some measures might not be worthwhile in guarding against them. ${ }^{380} \mathrm{~A}$ decentralized trading program can similarly restrict the number of allowances that may be acquired by any one pollution source. Jonathan Nash and Richard Revesz have proposed mechanisms for constraining emissions trades that would create hot spot problems, including an ingenious proposal to establish an internet-based clearinghouse that could instantly calculate the air quality impact of emissions at a particular time and place. ${ }^{381}$ Stephen Johnson has noted the use of information registers to record emissions, so that at least those exposed to the hot spots have the information to combat them..$^{382}$ In a land development context, a hot spot may be an area of particular environmental sensitivity that should not be developed at all. Transferable development rights programs address these hot spot issues by imposing restrictions on trading, limiting where development rights can be used. ${ }^{383} \mathrm{~A}$ number of options are available. The hot spot problem, to the extent it exists, is solvable.

The hot spot problem is in fact simply a specific aspect of a more general problem with any kind of efficiency-based program: one of inappropriate "commodification." Jim Salzman and J.B. Ruhl have questioned what environmental goods can appropriately be made the subject of a trade. ${ }^{384}$ If improperly designed, an efficiency-based program may permit a trade to occur that causes net environmental harm, and perhaps even causes environmental costs that are greater than the economic benefits. ${ }^{385}$

380. Programs that result in hot spots may nevertheless satisfy a wealth maximization criterion, but I have acknowledged throughout this article that I do not propose that efficiencythinking displace fairness-thinking entirely. Additionally,I do not propose that wealth maximization be the sole determinative criterion for environmental policy. The hot spot problem is one reason why I take this position.

381. Nash \& Revesz, supra note 377, at 624-58.

382. Stephen M. Johnson, Economics v. Equity II: The European Experience, 58 WASH. \& LEE L. REV. 417, 480 (2001).

383. See supra text accompanying notes $266-267$.

384. See James Salzman \& J.B. Ruhl, Currencies and the Commodification of Environmental Law, 53 STAN. L. REV. 607, 614-15 (2000).

385. Id., at 611-15. 
In decentralized trading programs, a mis-commodification occurs if the transfer of an allowance from one area to another may result in a higher marginal environmental damage, if the area receiving the permit (and suffering the additional pollution) is more sensitive than the area from which the permit came. A hot spot is thus nothing more than a problem of marginal damages being greater at one place than another. For an emissions trading program to ensure environmental benefits, the marginal benefits of emissions reduction must not vary too widely across areas between which permits may be traded ${ }^{386}$ or that some safeguards be put in place to protect such areas.

In regulatory bargaining programs, it is not just program design but regulatory discretion that may result in mis-commodification. In wetlands mitigation banking, a proposed wetland mitigation project must obtain the approval of the U.S. Army Corps of Engineers. ${ }^{387}$ It is thus up to the Corps to assess the merits of the proposed mitigation project-to create, enhance, or restore a wetland-as compensation for the destruction of another wetland. As commentators have noted, this program has been fraught with abuse.$^{388}$ When faced with the pleas of developers wishing to push through their development proposals, the Corps has found it extremely difficult to say no-hence an approval rate exceeding ninety percent for all dredge-and-fill permits under section 404 of the Clean Water Act. ${ }^{389}$ Wetlands mitigation has often involved the destruction of an ecologically valuable wetland, and the restored or created wetland has often been a poor ecological substitute. ${ }^{390}$ Lax monitoring of the wetland restoration and creation process has led to disappointing ecological results. ${ }^{391}$ The mis-commodification occurs when the Corps assigns value to a mitigation project that is based in fiction more than it is based in ecological reality. ${ }^{392}$

In Habitat Conservation Planning under the Endangered Species Act, the U.S. Fish and Wildlife Service is in effect bargaining with

386. An emissions trading system governing the emissions of carbon dioxide, for example, would be ideal in this respect since the problem of carbon dioxide emissions is one of aggregate emissions with no locational variation in terms of marginal damage, and no danger of creating a "hot spot."

387. Federal Water Pollution Control Act $\$ 404$ (a), (d), 33 U.S.C. $\S 1344$ (a), (d) (2003).

388. See Gardner, supra note 271, at 540-42; Michael J. Bean \& Lynn E. Dwyer, Mitigation Banking as an Endangered Species Conservation Tool, 30 ENVTL. L. REP. 10,537, 10,537-38 (2000).

389. David Sunding \& David Zilberman, The Economics of Environmental Regulation by Licensing: An Assessment of Recent Changes to the Wetland Permitting Process, 42 NAT. RES. J. $59,73 \&$ n. 66 (2002).

390. See, e.g., Gardner, supra note 271 at 540-42; Bean \& Dwyer, supra note 388.

391. See Salzman \& Ruhl, supra note 384 , at $652-53$.

392. See id. at $654-61$. 
developers, logging companies, and even states, ${ }^{393}$ permitting them to violate the Act in exchange for mitigation measures. Some of the deals have raised eyebrows. ${ }^{394}$ As in wetlands mitigation, the Fish and Wildlife Service has a propensity to take at face value the scientific opinion of the developer and her experts in evaluating the merits of mitigation measures, as well as their assessment of the potential for harm to endangered species. The chronically under-funded Service, in the meantime, lacks the resources to make a sound and independent assessment of the situation.

The problem with regulatory bargaining programs is that regulatory agencies are charged with acting as representatives of the public interest in an adversarial bargaining situation with private parties. Faced with political pressures from Congress and directly from the regulated entities, it is difficult for the agency not to find a way to accommodate the regulated entity. This might be corrected by more specific statutory mandates outlining the conditions under which deals might be struck. Under decentralized trading programs, this problem is at least dealt with in an upfront manner. Once decentralized trading programs are established, rent-seeking incentives are largely absent.

Commodification problems should be taken seriously and addressed, but they should not derail efficiency-based programs. All of the problems noted above can be corrected, although the ones pertaining to regulatory bargaining programs may be harder to fix ${ }^{395}$ But for decentralized trading programs, there is enough evidence thus far for detractors on the environmental side to ask themselves if they are missing the point. The point is not whether the environmental side is surrendering rights to the

393. See, e.g., Washington State Dep'T OF Natural Resources, Final Habitat Conservation Plan (1997); OR. Dep't of Forestry, Elliot State Forest Habitat CONSERVATION PLAN (1995).

394. The Service has sometimes asked for absurdly modest mitigation measures under Habitat Conservations Plans (HCPs). The Red Oak Timber Company of Louisiana purchased a 1,016-acre tract of forestland that provided habitat to two groups of red-cockaded woodpeckers, protected as "threatened" species under the ESA. Red Oak logged all but the 137 acres of the land inhabited by the woodpeckers, then sought an incidental take permit to log the rest. Red Oak submitted an HCP that involved relocating the two woodpeckers colonies to a nearby military base that had existing habitat. The total cost to Red Oak was $\$ 8,800$, approximately the amount of proceeds from the timber from five or six acres of the property. Incredibly, the Service agreed. Lost was one thousand acres of prime woodpecker habitat. DAVID S. WILCOVE ET AL., REBUILDING THE ARK: TOWARD A MORE EFFECTIVE ENDANGERED SPECIES ACT FOR PRIVATE LAND 8 (1996).

395. The U.S. Fish and Wildlife Service has been attempting to establish guidelines for establishing mitigation measures in Habitat Conservation Plans. The Service recently issued a guidance document setting forth rules for the establishment of conservation banks. Memorandum from Steve Williams, Director, U.S. Fish \& Wildlife Service, to U.S. Fish \& Wildlife Regional Directors, (May 2, 2003) (Guidance for the Establishment, Operation and Use of Conservation Banks), available at http://endangered.fws.gov/policies/conservationbanking.pdf. 
regulated side, but whether the exchange of rights can actually lead to environmental improvement. Realistically, the regulated side will always benefit from efficiency-based programs in terms of increased flexibility and lower compliance costs. But this is a benefit that might allow, for example, a more stringent cap to be put in place for a decentralized trading program. The $\mathrm{SO}_{2}$ emissions trading program achieved a fifty percent reduction in $\mathrm{SO}_{2}$ emissions nationwide; in order for $\mathrm{NOx}$ emissions to have been reduced by a similar fraction, highly draconian fairness-based measures would have been required, and would surely have been met with litigation from the regulated side. A benefit for the regulated side is thus not necessarily a bad thing for the environment.

\section{How Could We Have Overlooked the Benefits of Efficiency Programs?}

A famous joke pokes fun at economists' sometimes religiously devoted beliefs to the efficiency of markets. The joke begins with an economist and another person walking down the sidewalk when the latter spots a twenty-dollar bill lying on the sidewalk. She exclaims, "look, a twenty-dollar bill!" The economist scoffs, "that's not a twenty-dollar bill. If it was, someone would have picked it up already."

A skeptic could fairly ask, if these opportunities exist for achieving such vast economic gains, how is it that we have been blinded to such possibilities? If there really are such rich, welfare-enhancing possibilities, how is it that we could have overlooked them? There are a number of different explanations. First, among some environmentalists, there is still a lingering distrust of anything that uses the language of economics or utilitarianism. Some who call themselves environmentalists have simply rejected all ideas economic on the grounds that economic growth has, in their view, invariably led to some environmental harm somewhere, somehow. ${ }^{396}$ In 1993, Jane Perkins, then-President of the environmental organization Friends of the Earth, testified before Congress in opposition to the nomination of economist Lawrence Summers to a Treasury Undersecretary post because she felt that the post should be given to "a thinking, but feeling, person with a sense of justice." ${ }^{397}$ While hostility towards economics appears to be shrinking in the mainstream environmental movement, remnants remain. ${ }^{398}$

396. See, e.g., Scott Holwick, Transnational Corporate Behavior and its Disparate and Unjust Effects on the Indigenous Cultures and the Environment of Developing Nations: Jota v. Texaco, a Case Study, 11 COLO. J. INT'L ENVTL. L. \& POL'Y 183 (2000); HENDERSON, supra note 10.

397. David Wessel, Treasury Nominee Summers Sees Aid To Russia Near, WALl ST. J., Mar. $19,1993$.

398. See supra note 10. 
Second, an obsession with fairness encourages egocentrism, which perpetuates certain biases towards the status quo. ${ }^{399}$ For example, as noted above, Alaskan halibut fishermen at one point operated under an absurdly short and horrendously inefficient two-day fishing derby, while down the coast, halibut fishermen in British Columbia who were working under a vastly more efficient ITQ system were earning almost three times as much per pound by selling their fish into the much more lucrative fresh fish market. ${ }^{400}$ Amazingly, even while the Alaskan fishermen faced compelling evidence that they would all fare better by adopting a similar program, they were unable to agree on a fair initial allocation of quota shares. ${ }^{401}$ This is self-defeating egocentrism.

Third, an obsession with fairness encourages interest groups with a vested stake in maintaining the status quo to resist any policy changes that would jeopardize their regulation-created competitive advantage. ${ }^{402}$ The 1977 Clean Air Act Amendments prohibited the use of low-sulfur coal as a compliance strategy for attaining compliance with National Ambient Air Quality Standards, and instead required the installation of flue gas desulfurization technology, or "scrubbers." This served to preserve mining jobs in Eastern states, where high-sulfur coal is mined. This particular instance of policy inertia comes at the expense of the creation of jobs in Western states, where low-sulfur coal is mined. ${ }^{403}$ Due to identifiability problems, the fairness argument never seems quite as compelling for market entrants as it does for incumbents.

Fourth, some with a retributive sense of fairness have refused to agree to any measure that would inure to the benefit of the opposing side, even if benefits accrue to both sides. Some environmental organizations have opposed pollution permit programs and transferable fishing quota programs on the grounds that they "reward" polluters and "reward" overfishing, ${ }^{404}$ because some polluters and fishermen would reap financial

399. See Thompson, supra note 99, at 256-57.

400. NATIONAL RESEARCH COUNCIL, supra note 318 at 75-76; IUDICELLO, supra note 263, at 152. Discussed in more detail in text accompanying notes 329-331.

401. See IUCIDELLO, supra note 263 , at 149.

402. See Cass R. Sunstein, The Cost-Benefit State: The future of Regulatory PROTECTION 105-06 (2002).

403. BRYNER, supra note 34 , at 141.

404. Consider this missive from Greenpeace:

You may not know it yet, but corporate interests are about to gobble up the rights to species of fish and turn them into private property. With privatization we lose our rights to have a say about how the oceans - something we all share - are being treated

How? Through Individual Transferable Quotas (ITQs or IFQs), a scheme that would give certain individuals and businesses the rights to catch portions of our public resource.

ITQs are quotas "gifted" to the fishing industry based on how much they caught in the past. The more you caught, the bigger your "gift." In effect, this is a reward to those who caught the most (and therefore contributed most to the problems of over fishing) with the permanent right to keep fishing. 
gain through trading. Similarly, the unfortunate refusal of developing countries to participate in a global climate change treaty seems to be rooted in retributiveness. I do not deny that there are important expressive purposes for entering into a treaty. ${ }^{405} \mathrm{I}$ do not argue that the United States was correct in rejecting the Kyoto Protocol. However, because of the leakage problem, it would clearly have been the best outcome of all to have had an international agreement that included the developing countries. An unfortunate obsession with fairness (among other things) has blinded developing countries, which stand to suffer the most from global climate change, ${ }^{406}$ from recognizing the self-interest that would have been served by their participation in a global climate change treaty.

Finally, feuding stakeholders-most notably environmental organizations and regulated industries-may have simply learned to live with the existing fairness-based system, and are comfortable with it. ${ }^{407}$ While environmental policy debate driven by and formulated in the shadow of litigation is hardly efficient, it is the most familiar way of doing business for most stakeholder groups, dominated as they are by lawyers. Such an adversarial system reinforces itself, as it breeds distrust that further cements an adversarial posture..$^{408}$

No one would argue that our environmental policymaking process is perfect. I seek to identify, explain, and perhaps help solve one of the ways in which it has fallen short.

\section{TWO MODEST PROPOSALS}

How exactly do I propose to make environmental law take greater account of efficiency-oriented approaches? I make two modest proposals. First, Congress should pass legislation mandating cost-benefit analyses for a variety of environmental proposals, without making the analysis either a determinative criterion or a prerequisite for regulatory action. In effect, Congress should simply require that both Congress and agencies consider cost-benefit analyses in much the same way that they are forced to consider environmental impacts under the National Environmental

\footnotetext{
GREenPEACE USA, ITQS: PRIVATIZING OUR OCEANS, at http://www.greenpeaceusa.org/features/itq.htm (last visited Mar. 1, 2004). But cf. Stewart, supra note 42 , at $163-64$.

405. See, e.g., Oona Hathaway, Do Human Rights Treaties Make a Difference?, 111 YALE L.J. 1935, 2004-06 (2002).

406. NORDHAUS \& BOYER, supra note $251,4-31$ to 4-33.

407. See Stewart, supra note 42, at 164.

408. Robert Kagan has written on the phenomenon of "adversarial legalism," in which he believes that adversarial rules structures and an adversarial culture have fragmented political power and inhibited the development of sensible compromises, a problem which may be difficult to reverse. ROBERT KAGAN, ADVERSARIAL LEGALISM 245-47 (2001).
} 
Policy Act. ${ }^{409}$ Second, as befits someone locked into academia, I propose that greater use be made of Pigouvian taxes. Even small Pigouvian taxes on the consumption of fossil fuels can begin to address the enormous and varied environmental and social externalities caused by combustion, while limiting the role of government to the task which it ought to be doing: making determinations about the harms of pollution. I have no illusions about the political obstacles that stand in the way of putting user taxes in place. However, the chances may improve if a consensus can emerge among legal and economic academics on the desirability of Pigouvian taxation.

Congress has considered and rejected mandatory cost-benefit analyses on previous occasions. ${ }^{410}$ But the nature of these previous proposals, many of which were made during the period in which the antiregulatory "Contract With America" movement was in vogue, was to prohibit regulatory action unless a cost-benefit analysis made a specific finding that the benefits outweighed the costs. ${ }^{411}$ That is, these proposals envisioned cost-benefit analysis as a decision rule, and never as a positive driver in favor of regulation. I leave the debate over whether cost-benefit analyses should be absolute decision rules to others. My own position is clear: it should not. Pending outcome of that debate, however, it seems possible to agree that cost-benefit analysis provides information that we should have before us when making regulatory decisions.

My second proposal, to make use of Pigouvian taxes, has also been made before. ${ }^{412}$ Indeed, European Union countries make fairly extensive use of "green" taxes, which account for 6.5 percent of total tax

409. 42 U.S.C. $\$ \S 4321-4370 f(2003)$.

410. See, e.g., Comprehensive Regulatory Reform Act of 1995, S. 343, 104th Cong. (1995); Risk Assessment and Cost-Benefit Act of 1995, H.R. 1022, 104th Cong. (1995); Regulatory Improvement Act of 2000, H.R. 3311, 106th Cong. (1999).

411. For example, the Comprehensive Regulatory Reform Act of 1995 provided that "No final rule subject to this subchapter shall be promulgated unless the agency finds that ... the potential benefits to society from the rule outweigh the potential costs of the rule to society." $S$. 343, 104th Cong. $§ 623$ (1995). The Risk Assessment and Cost-Benefit Act of 1995 provided that "No final rule... shall be promulgated unless the agency certifies... the incremental risk reduction or other benefits of any strategy chosen will be likely to justify, and be reasonably related to, the incremental costs incurred." H.R. 1022, 104th Cong. § 202 (1995).

412. A report recently issued by the Association of Metropolitan Sewerage Agencies proposed a variety of taxes to help pay for wastewater infrastructure repairs and improvements. The proposed taxes included pollution taxes, along with increases in personal and real estate taxes. Susan Bruninga, Taxes on Pollution, Income, Seen as Sources For Infrastructure Trust Fund, Paper Says, 34 ENV'T ReP., Aug. 22, 2003, at 1879; see also William A. PIZER, PRICES vS. Quantities Revisited: THE CASE OF Climate ChANGE (Resources for the Future 1997); BAUMOL \& OATES, supra note 63, at 21-23; Jonathan Baert Wiener, Global Environmental Regulation: Instrument Choice in Legal Context, 108 YALE L.J. 677, 727-34 (1999); United Kingdom: New Report Indicates Industry Will Face Pollution Taxes, Tradable Emissions System, 21 INT'L ENVTL. ReP. 1114, Nov. 11, 1998; Pollution Taxes Could Boost Shift to New System, Former CBO Head Says, 28 ENV'T REP., Apr. 10, 1998, at 2655; Economic Advisors, EPA, Discuss Shift From Income Taxes to Pollution Taxes, 25 ENV'T REP., July 29, 1994, at 593. 
revenues. ${ }^{413}$ At the margins, the economic effects of Pigouvian taxation schemes are the same as for decentralized trading schemes-those who can most efficiently reduce pollution will undertake more reduction than others. ${ }^{414}$ In both programs, the polluter faces a marginal cost of pollution. In the Pigouvian tax scheme, it is simply the payment of the tax; in decentralized trading programs, it is the necessity of buying an extra allowance.

But Pigouvian taxes have been passed over in favor of decentralized trading programs, which essentially endow polluters with grandfathered rights to pollute. The $\mathrm{SO}_{2}$ emissions trading program allocated rights to polluting coal-fired power plants without charging them. Some coal-fired power plants, and even some $\mathrm{SO}_{2}$ allowance speculators, ${ }^{415}$ were able to turn a profit on the program. By contrast, a proposal to impose a Pigouvian tax on pollution would be an unambiguous and unavoidable cost for polluters. Thus, while the marginal effects of the $\mathrm{SO}_{2}$ emissions trading program were theoretically the same as a Pigouvian taxation scheme, the political reality is that any scheme using the word "tax" stands very little chance of passage. Similarly, a decentralized trading program that auctioned off allowances instead of granting them to polluters would amount to a tax, and would meet with similar resistance.

But Pigouvian taxation schemes can solve policy problems that decentralized trading programs cannot. It was a distributive sense of fairness that gave rise to the Clean Water Act requirement of nationally uniform effluent discharge standards. This is inefficient because it takes no account of the condition of the waters receiving the pollution. ${ }^{416}$ There is no reason to think that water pollution abatement has the same marginal benefit in Oregon as it does in Maine. One river could be of unusual ecological or aesthetic significance, while another might not. One might be fast-moving and able to rinse out impurities, while another may be sluggish and extremely sensitive to pollution. A Pigouvian taxation scheme could provide for different levels of taxation, on the basis of the

413. Joe Kirwin, Report Indicates Substantial Growth In European Union Environmental Taxes, 26 INT'L ENVTL. REP. 927, Sept. 24, 2003.

414. The question of whether Pigouvian taxes or allowance trading programs are superior is a complicated question that was first discussed in detail in 1974 by economist Martin Weitzman. Pigouvian taxes are essentially price controls, and allowance trading programs are essentially pollution quantity controls, and Weitzman showed that in the face of uncertainty in marginal control costs, price controls were generally economically more efficient when the marginal abatement cost curve was "steep" - that is, that it declined quickly as abatement decreased. On the other hand, quantity controls were more efficient when the marginal pollution damages curve was steep, i.e., when marginal damages rose quickly as pollution increased. See generally Martin L. Weitzman, Prices vs. Quantities, 41 REV. OF ECON. STUD. 477 (1974).

415. Swift, supra note 235 , at $362-63$.

416. To an extent, it was contemplated that water quality standards would play a role in providing for greater stringency where special ecological or aesthetic significance was involved. See Federal Water Pollution Control Act $\$ 301(b)(1)(C), 33$ U.S.C. $\S 1311(b)(1)(C)(2003)$. 
environmental harm involved. Again, this is what governmental agencies should do-determine the extent of harm, not determine the best method of compliance.

But if taxation levels varied across locations, wouldn't some pulp and paper mills move their business to a state with more lax standards? Putting aside the question of whether that would actually occur, if it did, that would be viewed by the economist as a desirable result. Better to move pulp and paper mills away from areas that are of special ecological significance. This is the essence of efficiency-all other things being equal, we want to present incentives to locate polluting activities where they cause less harm.

A Pigouvian tax might vary by location, but it would not vary by type of facility, as Clean Water Act standards currently do. While the EPA may successfully set standards in a way that equalizes the burdens across different industries (an unlikely prospect, and an invitation for whining), there is no connection between regulation and damage. Suppose two automobile plants sit beside each other on a riverbank. One makes ordinary sport-utility vehicles (SUVs), the other makes gargantuan Hummer vehicles. Hypothetically, assume that ensuring the tank-like durability and security of the Hummers requires a special industrial process that creates more pollution than the ordinary SUV plant. Do we cut the Hummer factory a break? Of course not. A higher Pigouvian tax is called for to account for the greater environmental harm. Economic efficiency requires that firms in a higher-polluting industry pay more for the greater harm caused. The extra cost may be passed on to Hummer consumers in the form of higher prices, but that would simply be the market's signal to consumers of the product that their consumption is imposing a greater external cost on society. If the pollution is bad enough, and the Pigouvian tax high enough, Hummers may become unaffordable and the Hummer plant may close. That would be an efficient result. If the pollution is so harmful that paying for it would result in the complete eradication of Hummers, then so be it. A Pigouvian tax would be the market's way of signaling that, given the pollution costs, Hummers are simply not worth having.

A Pigouvian taxation scheme would similarly replace the silly multitude of NOx emissions standards for different types of coal-fired power plants. The marginal damage of a ton of NOx emitted is utterly independent of the method of coal combustion-residents living on the shores of an acidified lake in upstate New York do not care whether it was a dry bottom wall-fired or a wet bottom coal-fired power plant that ruined their lake. It is a policy non-sequitur from their point of view, and from an economic view, to regulate on that basis. If some methods of coal combustion emit more NOx than others, those plants should be utilized less than cleaner ones that emit less NOx. Perhaps such dirty plants 
should even be shuttered. But economic efficiency would require, and a Pigouvian taxation scheme would help achieve, an economy in which we use the cleanest facilities to produce the same amount of electricity.

Driesen worries that a Pigouvian taxation scheme will fail because of the difficulty of determining the appropriate tax rate.$^{417}$ Flexibility for a governmental agency to change the tax rate to reflect changing realities about environmental impacts would pose uncertainty problems for polluters. In light of this, Driesen fears, governmental timidity may cause taxes to be set too low, and may also lead to a reluctance to change the tax level. ${ }^{418}$ But this objection is no different from that which could be made concerning any environmental law or regulation. In fact, the nature of an inquiry in setting Pigouvian taxes - the marginal harm caused by pollution-is narrower than that undertaken for other forms of regulation, and therefore less susceptible to self-serving and manipulative arguments and rent-seeking.

Indeed, perhaps the greatest benefit of a Pigouvian tax scheme is related to the democratization benefits that Sunstein and others have identified for decentralized trading programs. Challenges to the setting of Pigouvian taxes must necessarily focus on environmental harm. That is where public debate should be, not on what polluters can and cannot afford to do. Ideally, we would also have the other part of my proposal in place, and would have cost-benefit analysis available as a tool for determining (but not be the sole determinant of) the appropriate tax rate. Indeed, the democratization benefits of a Pigouvian tax scheme are greater than they are under decentralized trading programs.

Again, I have no illusions about the political realities facing such a proposal. But it is just possible that in the face of federal and state budget deficits as far as the eye can see, environmental organizations and deficit hawks could rediscover this old policy instrument, one that economists have been advocating for decades. A virulent American anti-tax phobia ${ }^{419}$ has thus far largely shut Pigouvian taxes out of environmental policy. But all streaks come to an end eventually. Concerns over funding for infrastructure repairs and upgrades have already induced our neighbor to the South, Mexico, to adopt pollution taxes as a strategy for curtailing pollution and raising revenue. ${ }^{420}$

417. DRIESEN, supra note 12 , at $68-70$.

418. Id.

419. See, eg., Michael Powell \& Christine Haughney, Wary of Higher Taxes, Officials Boost Fees, WASH. POST, Apr. 7, 2003, at A3 (describing how state officials facing fiscal crises are hiking user fees such as transit fares rather than raising income taxes).

420. John Nagel, Mexico Eyes Tax, Regulatory Changes to Boost Investment in Infrastructure, 26 INT'L ENVTL. REP. 945, Sept. 24, 2003. 


\section{CONCLUSION}

For many environmental problems, efficiency analysis must have a much greater role in policy analysis and especially political decisionmaking. Legislators, in particular, seem stuck in pie-slicing mode and unwilling to consider pie-baking possibilities. Perhaps this is their job, and Congress is meant to be purely an institution where fairness concerns are advocated. But policy discussion, particularly by interest groups, should be able to identify pie-baking possibilities and guide Congress towards more efficient policies.

It is difficult to identify pie-baking possibilities. It is harder still to hammer out the fairness issues that must be addressed in any legal transition, and harder even still is a transition from one type of regulatory regime with which we are familiar to a less familiar one. But failing to make that transition is to kick the can down the road, postponing the contentious issues for another day, as environmental litigation illustrates. A comparison of the development and implementation of decentralized trading programs with traditional fairness-based regulations bears this out. While hammering out the details of the $\mathrm{SO}_{2}$ emissions trading program was excruciating, protracted and ugly, the program has given environmental law a respite from the kind of litigation that has provided employment for environmental lawyers but pleased nobody else. The 1990 Clean Air Act Amendments, while a wonderful illustration of rentseeking, nevertheless served the purpose of getting the rent-seeking over with. The NOx rules under Title IV, by contrast, continue to be the bane of the EPA's existence.

Change is coming. Even technological optimists must concede that choices must be made in the coming decades. Already, it seems likely that some hard choices will have to be made to address global climate change. And we can be sure that many other problems will demand difficult choices. Environmental law has been predicated on a denial that difficult choices need to be made, and a denial of the unfairness that will be visited upon some members of society. Economics is a theory of choice, and perhaps this is why it has been unpopular among many in the environmental debate. We nevertheless need more of it now. 
